UNIVERSIDADE DE SÃO PAULO

FACULDADE DE EDUCAÇÃO

ANA PAULA YAZBEK

POR QUE É PRECISO CONHECER OS BEBÊS E AS CRIANÇAS BEM PEQUENAS PARA SER UMA BOA EDUCADORA DA PRIMEIRA INFÂNCIA? 


\title{
POR QUE É PRECISO CONHECER OS BEBÊS E AS CRIANÇAS BEM PEQUENAS PARA SER UMA BOA EDUCADORA DA PRIMEIRA INFÂNCIA?
}

\begin{abstract}
Dissertação apresentada ao Programa de Pós-Graduação da Faculdade de Educação da Universidade de São Paulo, na área de concentração Psicologia e Educação, sob a orientação da Profa. Dra. Rosa Iavelberg, com vistas à obtenção do título de mestre.
\end{abstract}

SÃO PAULO 
Autorizo a reprodução e divulgação total ou parcial deste trabalho, por qualquer meio convencional ou eletrônico, para fins de estudo e pesquisa, desde que citada a fonte.

Catalogação da Publicação

Ficha elaborada pelo Sistema de Geração Automática a partir de dados fornecidos pelo(a) autor(a) Bibliotecária da FE/USP: Nicolly Soares Leite - CRB-8/8204

Yazbek, Ana Paul POR QUE É PRECISO CONHECER OS BEBÊS E AS CRIANÇAS BEM PEQUENAS PARA SER UMA BOA EDUCADORA DA PRIMEIRA INFÂNCIA? / Ana Paula Yazbek; orientador Rosa Iavelberg. -- São Paulo, 2021.

$97 \mathrm{p}$.

Dissertação (Mestrado - Programa de Pós-Graduação Educação, Linguagem e Psicologia) - - Faculdade de Educação, Universidade de são Paulo, 2021.

1. Primeira Infância. 2. Brincar. 3. Autonomia. 4. Presença da Educadora. 5. Crianças. I. Iavelberg, Rosa, orient. II. Título. 


\section{FOLHA DE APROVAÇÃO}

Autor: Ana Paula Yazbek

Título: Por que é preciso conhecer os bebês e as crianças bem pequenas para ser uma boa educadora da primeira infância?

Dissertação apresentada em: para a banca examinadora 


\section{AGRADECIMENTOS}

Esta dissertação não teria sido escrita se o espaço ekoa não existisse, por isso agradeço a todas as crianças e as famílias que passaram pelo espaço. Essas pessoas apontaram os questionamentos e os caminhos para os cuidados e a educação dos bebês e das crianças bem pequenas.

Agradeço à Rosa Iavelberg por me acolher desde o exame de arguição, dando-me espaço e liberdade para seguir meu percurso, sempre oferecendo ajuda e fazendo apontamentos para que mantivesse meu foco.

À Lena Yazbek, minha mãe, por me apresentar Piaget na infância, fazendo-me perguntas sobre peso, tamanho e quantidade. Ainda hoje, se não tomar cuidado, posso achar que um quilo de algodão é bem mais leve do que um quilo de chumbo, ou seria o contrário? Agradeço, também, por ela e Amélia Nogueira, minha tia, terem atendido meus telefonemas e terem ingressado comigo na aventura de criar nossa linda escola para a primeiríssima infância.

Ao Marcos Santos Mourão, meu marido, pela interlocução contínua, encorajamento aos desafios e apoio aos meus projetos.

À Marina Yazbek Mourão e Pedro Yazbek Mourão, minha filha e meu filho, por me reapresentarem a infância e me mostrarem que o sempre e o nunca são circunstanciais.

À Maria Teresa Venceslau de Carvalho, minha querida amiga Teca, pela escuta e leitura atenta, por pegar na minha mão, fazer apontamentos e dar o fôlego final para a finalização deste texto.

À Karina de Queiroz Bueno, minha doce amiga, pelos apontamentos e leitura para o exame de qualificação.

À toda equipe de educadoras e educadores que já passaram pelo espaço ekoa, em especial às que contribuíram para este trabalho com seus olhares atentos ao cotidiano com os bebês e as crianças bem pequenas: Márcia Oliveira, Adriana Ferraz, Samantha Santos, Fabiana Rangel, Leticia Pereira e Vanessa Almeida.

À Heloisa Trigo pela parceria diária, por compartilhar o encantamento pelo trabalho com a primeiríssima infância e por se emocionar ao ouvir as considerações finais desta dissertação.

Ao Fábio Lisboa pela tradução tão zelosa do abstract.

Ao Carlos Bracher e Pila Zucca, por permitirem a continuidade de nossa escola.

Aos professores Zilma Morais Ramos de Oliveira e Lino de Macedo pelos apontamentos, sugestões e questionamentos colocados no exame de qualificação. 


\title{
RESUMO:
}

A presente pesquisa dedica-se à investigação da premissa de que é necessário conhecer quem são as crianças ${ }^{1}$ de zero a três anos para ser uma boa educadora ${ }^{2}$ desta faixa etária. Nesse percurso, buscam-se referências para definir a especificidade desse papel e ainda se levanta a discussão de existir uma pedagogia própria para a educadora de crianças pequenas. O estudo ainda intenta avaliar a atuação da educadora, particularmente no que ela pode favorecer ou dificultar o protagonismo das crianças. De maneira especial, a pesquisa enfatiza a reflexão sobre como as formas de interação e os modos de cuidar e educar interferem na construção da autonomia da criança. Para tanto, o exercício parte de um exame sobre as concepções de ensino de crianças e sobre quem é a criança bem pequena, ao mesmo tempo em que estabelece um diálogo com referências práticas da autora no trabalho cotidiano com os bebês e as crianças bem pequenas. Assim sendo, apontam-se possíveis caminhos para a especificidade do papel da profissional de educação de primeira infância.

Palavras-chave: crianças, educadoras, educação da primeira infância, brincar, autonomia, interação

\begin{abstract}
:
This research is dedicated to the investigation of the premise that it is necessary to know who children ${ }^{3}$ from zero to three years are old to be a good educator ${ }^{4}$ in this age group. Along this path, references are sought to define the specificity of this role and the discussion of the existence of a pedagogy for young children's educators is still raised. The study also intends to assess the role of the educator, particularly in terms of what she can favor or hinder the role of children. In a special way, the research emphasizes the reflection on how the forms of interaction and the ways of caring and educating interfere in the construction of the child's autonomy. Therefore, the exercise starts from an examination of the conceptions of teaching children and about who the young child is, while establishing a dialogue with the author's practical references in daily work with babies and young children. Therefore, possible paths for the specific role of the early childhood education professional are pointed out.
\end{abstract}

Keywords: children, educators, early childhood education, play, autonomy, interaction, Early Childhood Educator (ECE).

1 Refere-se às crianças e não alunos, tal qual aparece nos documentos oficiais, como a BNCC. http://basenacionalcomum.mec.gov.br/wp-content/uploads/2018/04/BNCC_19mar2018_versaofinal.pdf. Acesso em 01 jun. 2021.

2 Coloca-se aqui educadoras no feminino, pois as mulheres formam a maior parte dos profissionais nesta área da educação.

3 It refers to children and non-students as it appears in official documents such as the BNCC. http://basenacionalcomum.mec.gov.br/wp-content/uploads/2018/04/BNCC_19mar2018_versaofinal.pdf. Accessed on June 1st, 2021.

${ }^{4}$ Here we place female educators, as women form many professionals in this area of education. 
LISTA DE IMAGENS

Conjunto de imagens 1. Dezessete imagens que ilustram a narrativa

escrita por Márcia Oliveira, sobre a

colecionadora de sementes, 2017.

Conjunto de imagens 2. Duas imagens que ilustram a mini-história

escrita por Márcia Oliveira sobre uma troca de

fraldas, 2018.

Conjunto de imagens 3. Três imagens registradas por Samantha Santos

que ilustram a brincadeira com bobinas de plástico, 2018.

Conjunto de imagens 4. Foto registrada por Fabiana Rangel que ilustra a brincadeira de construção da Torre da Rapunzel, 2018.

Conjunto de imagens 5. Imagem registrada por Samantha Santos que ilustra a brincadeira com cones de papelão e bolinhas, 2018.

Conjunto de imagens 6. Duas imagens registradas por Leticia Pereira que ilustram a brincadeira do lobo, 2018.

Conjunto de imagens 7. Duas imagens registradas por Marina Mourão que ilustram a brincadeira de casinha, 2018.

Conjunto de imagens 8. Três imagens registradas por Samantha Santos da brincadeira de amarelinha, 2018.

Conjunto de imagens 9. Imagem registrada por Samantha Santos da brincadeira de alturinha, 2018.

Conjunto de imagens 10. Imagem registrada por Samantha Santos da brincadeira de alturinha, 2018.

Conjunto de imagens 11. Nove imagens dos espaços preparados para a oficina de 16 de maio de 2019.

Conjunto de imagens 12. Imagem do parque preparado para a oficina de artes de 16 de maio de 2019

Conjunto de imagens 13. Cinco imagens registradas por diferentes educadoras que compõem a narrativa do Menino e a Lama, 2018.

Conjunto de imagens 14. Treze imagens registradas por Leticia Pereira que ilustram a narrativa da Deriva, 2019.

Conjunto de imagens 15. Seis imagens registradas por Letícia Pereira que ilustram o uso dos elementos da natureza, 2019.

Conjunto de imagens 16. Imagem registrada por Adriana Ferraz que ilustra o momento do jantar dos bebês, 2019.

Conjunto de imagens 17. Seis imagens registradas por Sabrina Mantovanni e Adriana Ferraz que ilustram os bebês em suas experimentações com os materiais de artes, 2018.

Conjunto de imagens 18. Quatro imagens registradas por Sabrina Mantovanni que ilustram os bebês em outras experimentações com os materiais de artes, 2018. 


\section{SUMÁRIO}

INTRODUÇÃ

CAPÍTULO 1. PERCURSO METODOLÓGICO ……………………………….....13

CAPÍTULO 2. DESCRIÇÃO DO CAMPO_...........................................................19

CAPÍTULO 3.CONHECENDO OS BEBÊS E AS CRIANÇAS BEM PEQUENAS

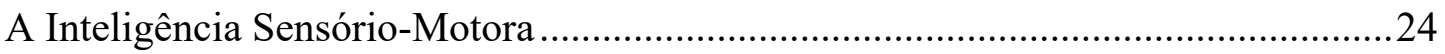

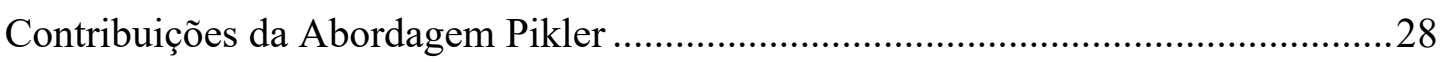

Estabelecendo um Diálogo entre a Inteligência Sensório-Motora e a Abordagem

Pikler a partir do Registro de uma Educadora...........................................................30

CAPÍTULO 4. UM OLHAR PARA AS SINGULARIDADES DAS CRIANÇAS

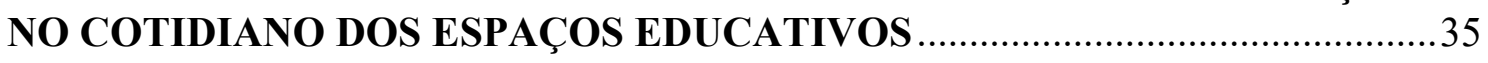

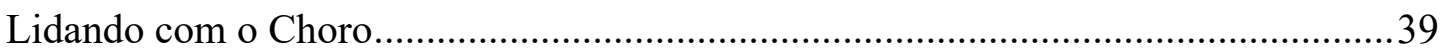

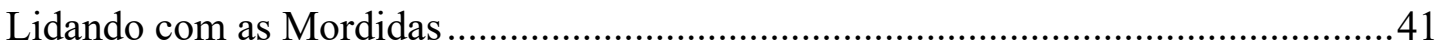

Crianças que Pouco Brincam .................................................................................. 44

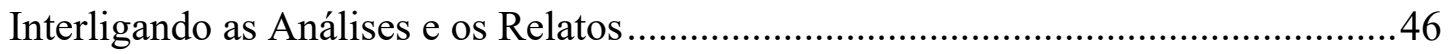

CAPÍTULO 5. O BRINCAR NO COTIDIANO EDUCATIVO .............................4 48

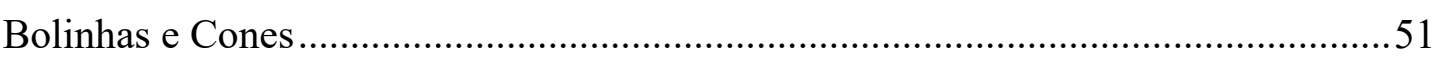

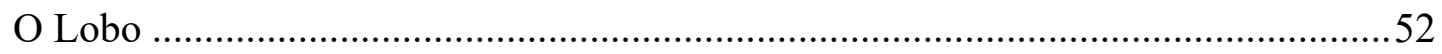

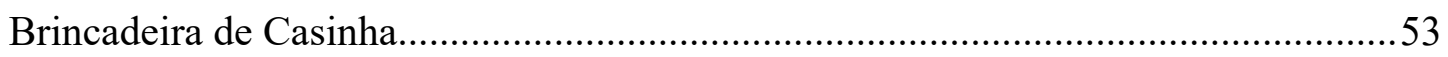

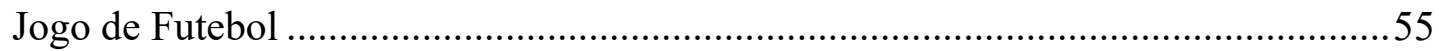

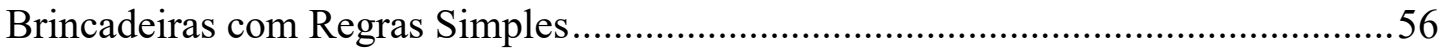

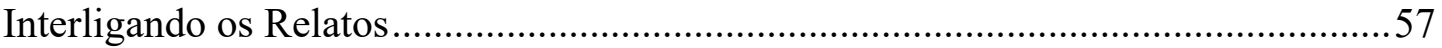

CAPÍTULO 6. O PAPEL DAS EXPERIÊNCIAS NA EDUCAÇÃO DOS BEBÊS E

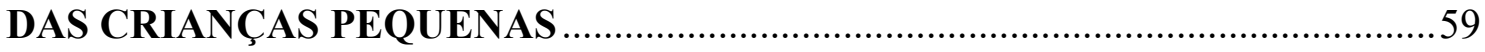

As Experiências das Crianças em Oficinas ..............................................................6 63

As Experriências dos Bebês .................................................................................. 73

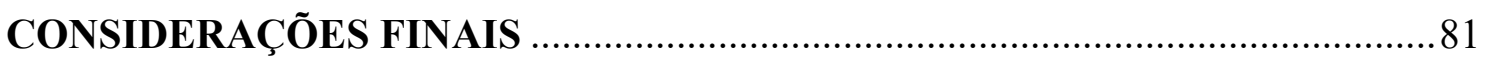

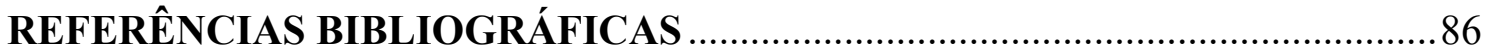

ANEXOS - TERMO DE CONSENTIMENTO E LIVRE ESCLARECIDO -

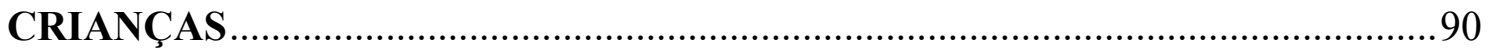




\section{INTRODUÇÃO}

A presente pesquisa faz um exercício de reflexão sobre a prática e o conhecimento de educadoras da primeira infância, observando os interesses e as capacidades dos bebês e crianças bem pequenas (entre quatro meses e dois anos e onze meses) para consolidação de uma ação educativa, construtiva e significativa para todos os envolvidos: crianças, famílias e educadoras.

Neste processo de investigação, torna-se necessária aclarar a experiência da pesquisadora que nasceu e viveu na escola. No ano de seu nascimento, 1970, sua mãe fundou uma escola particular no bairro de Pinheiros, em São Paulo, na qual ela estudou, até o final do ginásio (atual Fundamental II). Desde pequena, permanecia na escola no contraturno, brincando e, posteriormente, acompanhando a rotina das turmas de maternal, compostas por crianças de até um ano e meio. Quando concluiu o colegial (Ensino Médio), em 1989, ingressou na Faculdade de Educação da Universidade de São Paulo e começou a trabalhar numa escola particular de Educação Infantil. Desde então, vivencia diariamente o cotidiano de trabalho com crianças, famílias e educadoras.

Em seu percurso, a pesquisadora sempre atuou na Educação Infantil como professora em escolas particulares de São Paulo e como formadora de professoras, tanto nas redes públicas como particulares em diferentes localidades do território nacional. Desde 2002, é sócia-fundadora de uma escola particular ${ }^{5}$ da cidade de São Paulo que atende crianças de quatro meses e cinco anos e onze meses.

Entre 2002 e 2014, esteve voltada exclusivamente aos estudos e ao cotidiano educativo com as crianças entre quatro meses e dois anos e onze meses. A partir de 2014, ampliou seus estudos para as faixas etárias que envolvem a Educação Infantil. Ressaltase que ao longo desse percurso, a pesquisadora fez descobertas e levantou muitas indagações sobre as possibilidades de trabalho com a Educação Infantil. Baseou-se nos Referenciais Curriculares Nacionais para a Educação Infantil, de 1998, para a formatação do currículo de sua escola de educação de crianças de primeira infância. Em paralelo, buscou autores que poderiam embasar ainda mais seu trabalho e manteve-se atenta às maneiras como o cotidiano se constituía tanto em sua escola, como em outras escolas,

\footnotetext{
${ }^{5}$ A escola chama-se espaço ekoa e fica na região oeste da cidade de São Paulo, no bairro do Butantã. (www.espacoekoa.com.br).
} 
através do relato de educadoras e gestoras, em cursos, palestras e encontros do qual participou, como formadora ou mesmo ouvinte.

Desde o princípio, indagou-se sobre a possibilidade de existir uma pedagogia específica para a prática das educadoras de crianças pequenas, perguntando-se sobre qual seu papel na educação dos bebês e crianças bem pequenas. Interrogação essa que pauta, há muitos anos, boa parte das discussões sobre a singularidade do trabalho com essa faixa etária, uma vez que na sua origem a creche surgiu prioritariamente para garantir a assistência às famílias (principalmente, às mães) nos cuidados de seus(as) filhos(as). Esta pesquisa é fruto de suas questões e pretende sugerir pistas para a construção de possibilidades para o trabalho das educadoras com essa faixa etária.

Para tanto, o estudo considera necessário conhecer e descobrir quem é o bebê e a criança bem pequena (entre quatro meses e três anos), além de buscar ações e intervenções que possam favorecer cuidados educativos de qualidade que favoreçam seu bem-estar, como a imersão significativa e acesso aos objetos da cultura, além do incentivo à autonomia. Esta investigação parte do princípio de que a escola de primeira infância (creche/Educação Infantil) deve garantir ações de cuidados que priorizem o bem-estar físico e emocional das crianças e deve oferecer-lhes contextos de linguagens, movimentos, relacionamentos e brincadeiras de qualidade.

Esta pesquisa situa-se no campo da Pedagogia, entendendo-a como ciência que se constitui no cotidiano e nas relações estabelecidas entre crianças, educadoras e conhecimento. Vale lembrar que quando se fala de conhecimento para os bebês e crianças bem pequenas, se diz sobre estar no mundo e aprender a se relacionar com os objetos, pessoas, espaços e tempos. Trata, também, da necessidade de se fazer descobertas sobre o que ocorre ao seu redor e, com isso, perceber as regularidades e imprevisibilidades como formas possíveis de decodificar sua realidade. Tendo a Pedagogia como eixo central, esta pesquisa busca a intersecção com outras áreas do conhecimento - psicologia do desenvolvimento, psicanálise, etnografia, psicogeografia e arte - como fontes de elucidação que apoiam o entendimento de quem são o bebê e a criança pequena. Sendo assim, toma como referência a vivência prática da pesquisadora e busca produzir um diálogo com a práxis, entendida como as relações entre a teoria, a prática e as reflexões na ação educativa com os pequenos.

A necessidade de compreender os bebês e as crianças bem pequenas surgiu desde o princípio da atuação da presente pesquisadora com essa faixa etária, pois logo percebeu 
que para além de sua graciosidade existiam sujeitos que demandavam olhares múltiplos, marcados por sutilezas e detalhes. Seus desejos, interesses e ações não eram explicitados de formas evidentes e lineares. Suas recusas, muitas vezes, eram a maneira tortuosa de mostrarem que estavam concordando com o que os adultos empenhados em seus cuidados procuravam fazer. Por reconhecer essa complexidade, a autora compreendeu a necessidade de elucidar e decodificar quem são esses sujeitos.

Assim sendo, a pesquisa está dividida em seis capítulos que se seguem:

O primeiro capítulo situa o percurso metodológico a partir da descrição dos processos de produção desta pesquisa. Discorre sobre o contexto em que ela se organizou e quais caminhos foram escolhidos para que as reflexões da pesquisadora fossem esclarecidas e colocadas em confronto tanto aos leitores, como para ela mesma.

O segundo capítulo traz uma descrição do campo no qual a pesquisa se desenvolveu - local esse que a autora conhece muito bem. Nesse lugar, a pesquisadora imaginou, sonhou e, junto com sua equipe, com as crianças e suas famílias, consolidou sua prática diária e, para fins da pesquisa, usou de base para a construção e coleta de dados.

O terceiro capítulo apresenta a visão de bebês e crianças pequenas, caracterizandoos como sujeitos com interesses e desejos próprios. Ressaltando que esses sujeitos decodificam o mundo e necessitam de adultos zelosos que lhes oportunizem atenção, tempo, espaços, relações e materiais para que realizem suas descobertas.

Como referência, a investigação toma o epistemólogo-psicólogo suíço Jean Piaget (1986/1980) para se aproximar de como as crianças compreendem e interagem com o mundo, a partir de sua categorização da inteligência sensório-motora. Emmi Pikler (2010) e seus colaboradores do Instituto Pikler são outras referências, por suas contribuições para a consolidação de uma visão consistente sobre o trabalho das educadoras. Para fins desta pesquisa, destacam-se o modo como entendem a atuação nas interações durante as situações de cuidados, considerando os bebês, desde os primeiros instantes de vida, como sujeitos capazes de participar e tomar decisões.

No quarto capítulo, estabelece-se um diálogo com a visão psicanalítica, considerando suas contribuições para a construção do olhar da educadora na observação dos bebês e das crianças pequenas. Os conceitos relativos à constituição da vida psíquica, ideia de sujeito, subjetividade e intersubjetividade são tratados como primordiais para se 
pensar a relação que educadoras estabelecem com cada uma das crianças com as quais se relacionam diariamente.

No quinto capítulo, o brincar é colocado em destaque. Autores que abordam sua importância são tomados como referência, entre eles, destacam-se Bruner (2003) e Leontiev (1988), com suas concepções sobre o brincar livre e os brinquedos de largo alcance.

No sexto capítulo, discute-se o papel das experiências dos bebês e das crianças pequenas. Tomando emprestado o conceito de deriva da psicogeografia, é possível narrar sobre as ações e os deslocamentos das crianças, nos momentos em que circulam livremente pelos diferentes ambientes da escola. Propõe, ainda, uma reflexão sobre conceitos trazidos a partir das pedagogias participativas para pensar sobre como ocorre a participação dos bebês e das crianças pequenas no cotidiano educativo e em que medida suas escolhas são atendidas.

Por ser uma pesquisa que se pauta pelas perguntas da investigadora sobre os sentidos e significados das propostas educativas, voltadas às crianças pequenas e na busca de ações consistentes e reflexivas por parte das educadoras dessa faixa etária. Ao longo dos capítulos, são apresentados relatos e reflexões sobre experiências e descobertas, além de discussão sobre situações e problemas frequentes no cotidiano educativo, ilustrando, assim, a diversidade de conhecimentos que a pesquisa abrange. 


\title{
CAPÍTULO 1. PERCURSO METODOLÓGICO
}

\author{
Nunca ou muito raramente se pensa em coisas específicas, que dizem respeito \\ à minha experiência quando o conhecimento é permeabilizado por cheiros, \\ cores, dores e amores. Perdas, ansiedades e medos, todos esses intrusos que os \\ livros, sobretudo os famigerados "manuais" de Ciências Sociais teimam por \\ ignorar. (DAMATA, 1978. p.24)
}

Quantos cheiros, cores, dores e amores têm esta pesquisa? Quantas dúvidas, receios e desejos? Impossível mensurar! Mesmo buscando deixá-los de fora, para alcançar maior precisão nas palavras, eles teimavam em entrar. Às vezes trazendo fluência ao texto, outras vezes impedindo seu aprofundamento. Não foi intencional, mas, sim, algo que acontece quando a pesquisadora é a mesma pessoa que está imersa no campo pesquisado. A começar pelos motivos que deram origem à pesquisa: desejo de interlocução e inquietações diárias para realizar e construir uma educação de qualidade junto aos bebês e às crianças bem pequenas, na busca por consolidar uma prática educativa que respeitasse as especificidades dessa faixa etária, na formação de educadoras cada vez mais conscientes de seu papel e da importância da prática reflexiva para a realização de seu trabalho diário.

Junto disso, havia o desejo premente de colocar em confronto a prática educativa de sua escola de educação infantil, a fim de descobrir fragilidades, acertos e contrapontos, além de promover reflexões às outras educadoras que favorecessem o rompimento de modelos estereotipados tão usuais e, infelizmente valorizados, nas práticas educativas de muitas creches e escolas de primeira infância no Brasil.

Por se tratar de um mergulho em um cotidiano extremamente familiar, a autora enfrentou dificuldades em tomar distanciamento para busca por respostas a seus questionamentos. As leituras e referenciais teóricos foram fundamentais para fomentar novos olhares ao cotidiano. Desse modo, é uma pesquisa qualitativa que se situa no formato de estudo de caso, por estar imersa num contexto de vida real.

\begin{abstract}
As questões a investigar não se estabelecem mediante a operacionalização de variáveis, mas são, antes, formuladas com o objectivo de estudar fenómenos com toda a sua complexidade em contexto natural. As abordagens à metodologia qualitativa sofrem ou apresentam variações conforme as interpretações dos autores, mas aproximam-se nos aspectos fundamentais." (MEIRINHOS e OSÓRIO, 2010, p. 50.).
\end{abstract}

A partir do momento em que se propôs a pesquisar um campo extremamente conhecido, a pesquisadora traçou caminhos de observação que possibilitassem ver para além do que já via em seu cotidiano. A fim de verificar suas hipóteses, tomou 
distanciamento, fez anotações, buscou referências teóricas, aproximou-se das crianças e de suas educadoras, lançou perguntas, às vezes em voz alta e outras vezes somente para si e ouviu os silêncios, os barulhos e as narrativas como possibilidades interessantes de respostas. Dedicou-se à observação das crianças em propostas dirigidas e nas brincadeiras e, a partir delas, construiu hipóteses e produziu reflexões sobre a importância de se conhecer os bebês e as crianças pequenas para ser uma boa educadora dessa faixa etária.

A pesquisa ocorreu de modo formal entre os anos de 2018 e 2019, mas foi permeada por experiências e pensamentos de todo o percurso profissional da autora, mais especificamente a partir de 2002, até a data de conclusão desta dissertação, no primeiro semestre de 2021.Ao longo da pesquisa, a autora procurou dar destaque a diferentes momentos e situações protagonizadas pelos diversos sujeitos: bebês, crianças pequenas e seus familiares, assim como educadoras de sua escola. As crianças, em sua maioria, estavam entre dez meses e dois anos e onze meses. Filhas de pais e mães trabalhadores, profissionais liberais, professores, profissionais da saúde e pequenos empresários, que valorizam o brincar e a Educação Infantil. As educadoras são pedagogas formadas ou em formação, em sua maioria estudaram em escolas públicas e fizeram a graduação em faculdades particulares.

\section{Referenciais Metodológicos}

Na busca por referenciais, ao ler a dissertação de mestrado de Paulo Fochi (2013), a autora tomou conhecimento do livro Métodos de Pesquisa em Ciências Sociais de Howard Becker (1993, p.12), do qual destaca o seguinte trecho:

[...] prefiro um modelo artesanal de ciência, no qual cada trabalhador produz as teorias e métodos necessários para o trabalho que está sendo feito. [...] os sociólogos podem desenvolver as ideias mais relevantes para os fenômenos que eles próprios revelaram. [...] os sociólogos deveriam se sentir livres para inventar os métodos capazes de resolver os problemas das pesquisas que estão fazendo.

Partindo desta ideia de artesania, organizou em tópicos os pontos que lhe pareciam interessantes de destacar, questionar e refletir. Inicialmente, pensava em discutir sobre a especificidade da educadora de bebês e crianças pequenas e refletir sobre seu papel. Mas, após o exame de qualificação, percebeu que faltava objetividade e uma pergunta central. Ao ler e reler o que havia produzido até então, deu-se conta de que a todo momento buscava entender quem são as crianças pequenas, como se relacionam com o mundo e 
como respondem às diferentes situações que lhes são propostas. Procurou, então, delinear um diálogo com teorias e abordagens teóricas que consideram as crianças como sujeitos competentes e afinou seu olhar para compreender as respostas dadas por elas.

Ao longo da pesquisa, sentiu dificuldade em tomar distanciamento do objeto pesquisado, pois sempre esteve em relação direta ao cotidiano do campo estudado e sentia necessidade de falar sobre suas vivências e inquietações sobre o trabalho com as crianças pequenas e o trabalho de formação com as educadoras. "Seria possível dizer que o elemento que se insinua no trabalho de campo é o sentimento e a emoção. Estes seriam, para parafrasear Lévi-Strauss, os hóspedes não convidados da situação etnográfica". (DA MATA,1978, p. 30). No caso desta pesquisa, pode-se dizer que a emoção é mais do que um hóspede, é também, protagonista que interferiu em cada tomada de decisão.

Para dar conta do distanciamento, a autora procurou instituir um diálogo com os referenciais teóricos escolhidos, apesar de saber que não seriam suficientes para todas as respostas. Assim, a partir do levantamento bibliográfico e relatos sobre a prática, esta pesquisa foi se constituindo.

As leituras, fichamentos e resenhas forneceram o entrelaçamento entre os diferentes autores e estudos feitos sobre a educação dos bebês e das crianças bem pequenas, assim como as maneiras como o papel das educadoras dessa faixa etária são concebidas.

Identificava que por mais experiência que tivesse em aspectos comuns na rotina diária com crianças, familiares e educadoras, cada uma das situações precisava ser compreendida como únicas. Exemplificando, todos seus saberes sobre a adaptação de crianças ao contexto da escola, a auxiliavam a pensar em caminhos para que ela transcorresse de modo mais fluído e tranquilo, mas não solucionavam os problemas e dificuldades enfrentados, pois cada adaptação deveria ser compreendida como um processo singular que precisava ser vivido pelas crianças, familiares e educadoras. Afinal, cada uma delas estava sentindo, estranhando e buscando maneiras de lidar com esse "novo" que se apresentava.

Os registros, imagens, anotações, sínteses de encontros com a equipe de trabalho serviram de base para construção de dados e para a formulação de novas perguntas sobre as especificidades do trabalho educativo na primeira infância. 
A pesquisa etnográfica, tal como descrita por William Corsaro (2002), foi fundamental para uma melhor aproximação ao universo da infância, contribuindo tanto para a realização da pesquisa, como para se pensar na possibilidade das educadoras se colocarem em outros pontos de vista para compreender como pensam e agem as crianças.

\begin{abstract}
Etnografia é o método que os antropólogos utilizam mais frequentemente para estudar culturas exóticas. Este método requer que o investigador entre, seja aceite e participe nas vidas daqueles que estuda. Neste sentido, a etnografia implica, por assim dizer, "tornar-se nativo". Estou convencido de que as crianças têm as suas próprias culturas e eu sempre quis tornar-me parte de e documentá-las. Para fazer isso eu precisei de entrar nas vidas quotidianas das crianças - para ser uma das crianças o melhor que pudesse". (CORSARO, 2002, p. 02).
\end{abstract}

Em muitos momentos, a autora esteve próxima das crianças, sentava-se no chão, de modo a não atrapalhar seus deslocamentos e ficava em espaços menos frequentados pelos demais adultos. Procurava não interagir, mas respondia sempre que as crianças solicitavam sua ajuda, ou faziam alguma pergunta.

(...) a observação participante é um dos procedimentos de observação mais utilizados na investigação qualitativa. O fundamental desta observação participante é a integração do investigador no campo de observação. Observa desde a perspectiva de um membro participante, mas também pode influenciar o que observa devido à sua participação. Neste sentido, o observador pode tornar-se parte activa do campo observado". (MEIRINHOS e OSÓRIO, 2010, p. 60).

Muitas observações foram registradas em imagens (fotos e vídeos) e algumas delas foram narradas em diários e breves anotações no caderno de notas da pesquisadora e serviram como base para a construção de dados. As orientações e registros das educadoras da escola também foram elementos significativos para essa etapa da pesquisa.

Cada capítulo foi escrito com a intenção de trazer novos sentidos às vivências e às propostas, assim como instituir diálogos, fazer perguntas e buscar respostas a questionamentos trazidos por teóricos e estudiosos da infância. O que os bebês contam sobre si quando estão iniciando seu percurso em espaços coletivos como creches e escolas? O que os teóricos falam sobre eles faz mesmo sentido quando os observamos? $\mathrm{O}$ que as crianças dizem sem usar a fala, pelo choro, pelas recusas, pelos gestos e silêncios? Será que as educadoras as escutam efetivamente, ou propõem-se a escutá-las?

As brincadeiras, direito fundamental e destacado na Base Nacional Comum Curricular (BNCC), são efetivamente formas de expressão, interação e aproximação aos conhecimentos? O que ocorre quando a criança não brinca? O que ocorre quando os 
adultos não se aproximam para compreender as brincadeiras das crianças? Há intencionalidade nas ações e foco em seus interesses ou as crianças são guiadas pelas circunstâncias? O que as experiências proporcionam? Será que prazer e desprazer são polos opostos e devem ser evitados ou será que promovem aprendizagens?

A fim de oferecer respostas e pensar em caminhos possíveis, os capítulos que se seguem foram carregados de cheiros, cores, amores, dúvidas e receios. Os dados coletados a partir das observações foram iluminados pelos apontamentos teóricos que favoreciam a ampliação do que era percebido. A fim de preservar a privacidade das crianças e demais atores das situações pesquisadas, quando os registros do caderno de campo suscitavam uma possibilidade de exposição desnecessária, que poderiam inclusive comprometer o compromisso ético da pesquisa, optou-se por produzir uma reflexão mais abrangente, pois como descreve Buss-Simão (2014, p. 54), "o pesquisador deve trabalhar de modo reflexivo e cuidadoso, tendo como ponto de partida a premissa de que os direitos éticos das crianças são iguais aos dos adultos".

No capítulo quatro, por exemplo, sobre a singularidade das crianças, nas anotações iniciais, havia a descrição de situações que apresentavam as crianças em momentos mais delicados, nos quais o choro, a raiva, a agressividade ocupavam lugar de destaque e poderiam desviar a atenção do leitor para um incômodo frente ao desconforto (sofrimento) das crianças, ao invés de evidenciar a necessidade e o esforço das educadoras em compreender, traduzir e ressignificar o que elas diziam "às avessas". É fato que no cotidiano dos espaços educativos há instantes delicados, afinal é um espaço de convívio humano, permeado pelas emoções, pelos encontros e desencontros, por isso a necessidade de atenção e respeito ao que merece ser narrado e compartilhado e ao que deve ser mantido em privacidade e segurança. Isto não quer dizer que temáticas delicadas não devam ser tratadas ou devam ser ocultadas, pelo contrário, ao serem tocadas, precisam ser cuidadas em sua inteireza, respeitando as fragilidades de todas as condições e pessoas envolvidas, mas na busca de soluções e mudanças. Vale pensar que no alívio da dor, os bons profissionais da saúde, fisioterapeutas, por exemplo, tocam com gentileza nos pontos sensíveis, mesmo quando provocam uma dor maior é porque sabem que em seguida será proporcionado um maior bem-estar.

Nas situações em que as ações das crianças mereciam ser colocadas em destaque, numa tentativa de aproximação de seu olhar, fazer, pensar e agir, optou-se pelo registro de narrativas imagéticas, as mini-histórias, pois como descreve Rinaldi (2021, p. IX): 
Elas tornam visíveis, de modo parcial e subjetivo, os processos e as estratégias de aprendizagem usados pelas crianças, individual e coletivamente. Elas permitem ler, revisitar e avaliar - ações que são parte integral do processo de construção de conhecimento. Elas são essenciais para entender processos cognitivos, bem como relações entre crianças e adultos.

As mini-histórias são uma forma de documentar o trabalho realizado com as crianças, a partir de sequências de imagens selecionadas e breves relatos que narram as descobertas, interesses, dúvidas, conquistas e ações das crianças. São amplamente usadas pelas escolas de Reggio Emilia com o intuito de dar voz, autoria e visibilidade às ações das crianças.

No âmbito desta pesquisa, o registro feito a partir de mini-histórias fez-se necessário por oferecer um caminho para a construção do olhar das educadoras, pois ao observarem as crianças, elas podem descobrir regularidades em suas ações, assim como coletarem pistas sobre o que mobiliza seus interesses. Ao dar destaque a uma situação trivial, as educadoras podem entender melhor como uma criança se envolve em determinadas situações e como busca respostas àquilo que procura compreender, tornando significativa e carregada de sentidos determinada ação que num primeiro momento parece circunstancial ou frívola. 


\section{CAPÍTULO 2. DESCRIÇÃO DO CAMPO}

A pesquisa foi realizada no espaço ekoa, escola particular de Educação Infantil, da qual a autora é diretora e idealizadora de seu projeto pedagógico. Em seu início, no ano de 2002, a escola atendia crianças entre quatro meses e três anos, a partir de 2014 começou a atender crianças até quatro anos e, em 2019, passou a atender todo o ciclo da Educação Infantil, dos quatro meses aos cinco anos de onze meses.

Desde o princípio, tinha como objetivo criar uma escola que se distinguisse das demais, que olhasse para a educação dos bebês e das crianças bem pequenas de modo amplo, considerando suas potencialidades e complexidade, para além do que o senso comum traduzia como fundamental ao atendimento dessa faixa etária.

Desafio e segurança sempre foram pilares fundamentais desse projeto. A escola foi projetada de forma a oferecer amplas possibilidades de exploração pelas crianças. Todo o espaço pode ser usado por todas as turmas, sem que tenham uma sala de aula específica e boa parte das situações ocorrem na área externa, sendo possível a movimentação e deslocamento das crianças em todos os momentos. Há poucas paredes que separam o dentro e o fora. É possível estar num ambiente fechado e observar o que ocorre do lado de fora pelas amplas portas, sempre abertas, ou pelas vidraças de alguns locais. A topologia do terreno foi especialmente desenhada para que pudessem experimentar maneiras diferentes de transitar. Rampas, aclives, desníveis, morros, platôs, gramados, pisos duros (concreto e tijolo), tanques de areia, árvores e muita vegetação compõem os ambientes externos e oferecem maneiras diversificadas de deslocamento.

Em 2003, o currículo do espaço ekoa foi estruturado em quatro eixos norteadores do trabalho $\left.{ }^{6}: 1\right)$ identidade e autonomia; 2) linguagem oral e situações de comunicação; 3) desafios lúdicos e motores e, 4) conhecimento de mundo - com o propósito de desenvolver um conjunto de práticas que articulassem os cuidados entre o bem-estar e os saberes sobre a infância com os conhecimentos que fazem parte do patrimônio cultural,

\footnotetext{
${ }^{6}$ Os Referenciais Curriculares para Educação Infantil do MEC de 1998 foram a base para a estruturação do currículo, mas optou-se por não desmembrar em áreas o eixo de conhecimento de mundo, por considerar que nessa faixa etária as aprendizagens ocorrem de modos amplos e integrados. O que, posteriormente, foi indicado nas Diretrizes Curriculares Nacionais para Educação Infantil de 2010 e agora aparece de modo mais explícito nos Campos e Experiências da Base Nacional Comum Curricular de 2018.
} 
artístico, ambiental, científico e tecnológico, de modo a promover o desenvolvimento integral das crianças dessa faixa etária.

O eixo curricular de identidade e autonomia busca desenvolver um grande conteúdo: a autonomia emocional e outros conteúdos decorrentes do primeiro; a convivência em grupo; o reconhecimento dos pertences/características pessoais e, os cuidados com o corpo. Considera-se autonomia emocional a possibilidade e a capacidade da criança em sentir-se segura num espaço diferente do seu ambiente de convívio familiar, conseguindo se expressar, se relacionar e participar de diferentes propostas oferecidas, de forma integral, reconhecendo as pessoas que podem ajudá-la em caso de necessidade e sentindo-se encorajada a buscar formas particulares de resolução de problemas que surgem no dia a dia.

Reconhece-se que essa é uma faixa etária na qual o colo, o afeto e o carinho são fundamentais e essenciais para a garantia do bem-estar físico, emocional e cognitivo das crianças, ao mesmo tempo em que se distingue como sendo de extrema importância que percebam que podem experimentar maneiras de lidar com suas dificuldades e que sempre poderão contar com o auxílio de suas educadoras. A segurança de que estão sob os cuidados de adultos que as respeitam, ocorre tanto nos momentos de cuidados pessoais, como nas situações planejadas, em que cada criança pode brincar e interagir com objetos e propostas.

Considera-se relevante garantir um ambiente que favoreça o reconhecimento, por parte das crianças, de algumas de suas necessidades (sejam elas físicas - sono, alimentação, ausência de dor, ou relativas à atenção/interação - colo, partilha de brinquedos) e que garanta a busca de uma resolução desses incômodos, mesmo que seja através de um pedido de ajuda ao adulto. Nesse eixo curricular, estão envolvidas todas as situações relacionadas aos cuidados, autocuidado e ao bem-estar físico (banhos, troca de fraldas, sono e alimentação). Esse eixo abrange, também, a criação de um ambiente de convívio social amistoso em que, progressivamente, as crianças passam a reconhecer todos os indivíduos que fazem parte dessa nova comunidade (suas educadoras, seus colegas e, posteriormente, os funcionários e familiares de colegas que transitam por ali), assim como objetos e situações que as identifiquem.

No eixo curricular de linguagem oral e situações de comunicação, o trabalho volta-se para o entendimento da comunicação em seus contextos mais amplos. Não restringindo-se apenas à fala e à conquista do discurso oral, mas também às inúmeras 
situações em que ocorrem a interlocução entre as educadoras e as crianças e das crianças entre si. Nas interações com os bebês, busca-se compreender o que eles estão querendo comunicar em suas ações espontâneas, choro, trocas de olhares, sorrisos, gestos, balbucios, ações físicas e as primeiras palavras.

As situações de atendimento aos cuidados físicos, como banho, alimentação e troca de fraldas são momentos privilegiados para o estabelecimento da comunicação com a criança. Propiciam conversas e trocas de olhares significativos, tanto para a criança, como para a educadora envolvida na tarefa. Nesses momentos, as educadoras procuram nomear e até traduzir as diferentes expressões de cada criança, pois reconhecem que os gestos e olhares fazem parte de um discurso não oral da criança. Procuram entender o significado de cada choro, pois eles se escondem por trás de diferentes nomes (sono, fome, "quero colo", entre outros).

Nesses contatos cotidianos, estabelecem muitas conversas com os bebês, assim como brincadeiras em que ocorrem a imitação dos sons e balbucios que eles tanto emitem, quando em contato com os adultos. Com as crianças maiores, essas interações ocorrem intensamente nos diferentes períodos do dia, em conversas informais sobre suas roupas e objetos que trazem de casa; na solicitação da realização de favores, como dar recados às outras educadoras, informar na cozinha quantas crianças participarão da refeição, ou levar objetos para serem consertados pelos funcionários da manutenção; nas situações em roda quando conversas são estabelecidas com e entre as crianças a partir de um tema colocado em pauta por algum dos participantes (crianças ou educadoras).

No eixo de desafios lúdicos e motores, as ações educativas contemplam as possibilidades motoras das crianças e a criação de inúmeras situações de vivências lúdicas e brincadeiras que favorecem a interação das crianças entre si e entre os diferentes objetos e brinquedos. Atribui-se extrema importância à atividade lúdica e motora da criança, pois se caracterizam como as principais atividades propulsoras do desenvolvimento da inteligência nessa etapa da vida. Afinal, é pela ação física que as crianças fazem suas primeiras explorações pelo mundo. Basta, por exemplo, observar a alegria de um bebê ao descobrir as possibilidades de interação com os objetos que suas mãos lhe oferecem. E, é pela interação lúdica que ocorre sua interlocução inicial com os outros indivíduos (mesmo aquelas bem iniciais que intuitivamente envolvem pais e filhos, como as trocas de olhares, sorrisos e feições). Considera-se, assim, as atividades lúdicas como eficientes canais de comunicação da criança com o mundo exterior. Não se emprega o caráter lúdico 
das atividades como forma de mascarar algum conteúdo de aprendizagem. Isto é, quando uma brincadeira é proposta ao grupo de crianças, o objetivo é garantir o divertimento, a ação física e as relações interpessoais. Se a brincadeira envolve a récita da sequência numérica, ela é favorecida e as crianças entram em contato com uma situação convencional em que são incentivadas a falar os nomes dos números, simplesmente.

As situações de brincadeira fazem parte da rotina diária. Elas ocorrem nos contatos informais estabelecidos com as crianças e em situações planejadas para todo grupo ou parte dele. Nas brincadeiras, busca-se oferecer desafios a serem transpostos, divertimento e inúmeras possibilidades que favoreçam a partilha de objetos e o estabelecimento de diálogos, mesmo que ainda rudimentares, com os colegas e educadoras.

No eixo de conhecimento de mundo, as ações educativas contemplam o contato das crianças com o entorno (o jardim, a horta e os bichinhos de jardim), com procedimentos de artes nas diferentes modalidades (desenho, modelagem, colagem e pintura), com informações diversas de animais e com os objetos da cultura. Nesse eixo, as situações de aprendizagem são organizadas de forma a garantir a participação das crianças, partindo sempre daquilo que elas já conhecem e agregando novas informações sobre o objeto de conhecimento, sempre garantindo a possibilidade de exploração.

No trabalho a partir de eixos buscam-se ao mesmo tempo olhar para pontos específicos de cada um deles e sua integração. Criam-se contextos para que as crianças possam brincar, conversar, movimentar-se, relacionar-se e expressar-se de diferentes maneiras, garantindo circunstâncias lúdicas e/ou de comunicação que sejam significativas, além da integração e cumplicidade entre as crianças. Não é esperado que elas reapresentem conteúdos e conceitos prontos e acabados, consideram-se que as aprendizagens decorrentes das situações propostas são inerentes aos contextos criados. Isto é, sem que haja um controle ou objetivos finais de aprendizagem, as crianças realizam muitas aprendizagens, algumas que são visíveis e valorizadas pelos adultos e outras que são compreendidas de forma subjetiva e outras que ficam guardadas para si.

Esse projeto educativo partiu do princípio de que primeiro seria necessário conhecer as crianças, conhecer suas formas de expressão, interação e maneiras de estabelecerem relações com as pessoas (adultos e crianças) e com o mundo ao seu redor. Desde o início, buscou formas de atender a essas crianças, levando em consideração 
questões relativas às singularidades de cada uma e as maneiras de inseri-las num espaço coletivo, com uma rotina integrada e estruturada para esse atendimento.

As turmas são multietárias, as menores compostas por bebês entre quatro meses e um ano e quatro meses, outra por crianças entre um ano e quatro meses e três anos e outra composta por crianças entre três anos e cinco anos e onze meses. Embora o convívio entre as crianças das diferentes turmas seja frequente, normalmente, as crianças permanecem em interação com seu grupo e com suas educadoras de referência. Os encontros são marcados por manifestações de interesse, ajuda das crianças maiores aos deslocamentos das menores, expressões de carinho e cumplicidade.

Para a efetivação desse projeto pedagógico foi preciso organizar estruturas e processos de formação internos das educadoras, a fim de consolidar, construir e aprimorar suas competências. Há reuniões pedagógicas semanais com toda equipe, nas quais são realizados estudos e leituras de textos que favorecem a interlocução entre vivências práticas e conceitos teóricos que são observados no cotidiano do trabalho. Nas reuniões, ocorrem situações de tematização da prática a partir de relatos feitos pelas educadoras ou de filmagens de propostas e vivências realizadas com as crianças. A partir da análise de cenas filmadas, ocorrem discussões sobre diferentes possibilidades de encaminhamentos de futuras propostas e, também, a construção de diferentes olhares sobre as ações das crianças e das educadoras, favorecendo ajustes para situações futuras e atenção aos detalhes que escapam no transcorrer das propostas.

A formação continuada ocorre, também, em outras instâncias, com assessorias de especialistas, conversas com pediatras e equipes de saúde, produção de registros e documentação do trabalho. Além do acompanhamento diário com conversas informais e reuniões individuais, nas quais as educadoras partilham com a coordenação suas expectativas, dúvidas e anseios com relação a seu trabalho.

O clima instituído é prioritariamente de escuta e parceria e, assim como com as crianças, o erro e as inadequações são tomados como pontos de reflexão e ajustes e não necessariamente como algo grave. Objetiva-se construção de um olhar reflexivo e ampliado para o que acontece no dia a dia e não a mera aplicação de propostas repetitivas e destituídas de sentido tanto para as crianças como para as educadoras. 


\section{CAPÍTULO 3. CONHECENDO OS BEBÊS E AS CRIANÇAS BEM PEQUENAS}

\section{A Inteligência Sensório-Motora}

[...] é no momento em que o sujeito está mais centrado em si próprio que ele menos se conhece; e é na medida em que ele se descobre que passa a situar-se em um universo e, por esse mesmo fato, o constitui. Por outras palavras, egocentrismo significa, simultaneamente, ausência da consciência de si e ausência de objetividade, ao passo que a posse do objeto, como tal é paralela à aquisição da consciência de si. (PIAGET,1979, p. 08).

Muito antes de iniciar esta pesquisa, no ano de 1993, a autora era professora de crianças de três e quatro anos e por sugestão da orientadora pedagógica da escola que trabalhava, leu livro A representação do mundo na criança (PIAGET, 2008). Foi como se tivesse colocado óculos, aparelhos auditivos e sensores pelo corpo todo que a aproximaram do modo como as crianças se relacionam com o mundo e com o conhecimento. Gestos sutis, olhares fixos e falas graciosas das crianças foram compreendidos como maneiras de explicitarem seus entendimentos e de se relacionarem com o que ocorre ao seu redor.

A partir daí, iniciou sua busca por conhecer como as crianças pensam, pois considerava que isto a auxiliaria a promover melhores encontros de saberes e a compreender o que ocasionavam os desencontros. As ideias fantásticas das crianças sobre o funcionamento do universo, suas fabulações, além de causarem grande encantamento, favoreciam a busca por caminhos sobre o que propor a elas, como incentivar suas pesquisas, como oferecer contextos ampliados de aprendizagem e oferecer provas e contraprovas ao que manifestavam. Nessa aproximação ao pensamento infantil, compreendeu que as assimilações ${ }^{7}$ ocorriam por intermédio de modos próprios, nos quais cabiam justificativas próximas às convencionais e a permanência de explicações animistas/fantásticas, comuns ao pensamento infantil.

Ao iniciar seu percurso como educadora e formadora de educadoras das crianças bem pequenas, sentiu a necessidade de se aproximar dos estudos que descreviam como eram a inteligência e a forma dessas crianças se relacionarem com o mundo, uma vez que

\footnotetext{
${ }^{7}$ Assimilação é um conceito fundamental da teoria piagetiana sobre o modo como o individuo busca compreender o novo, primeiramente incorporando e moldando-o às suas estruturas de compreensão. (PIAGET. 1973).
} 
notava diferenças significativas em relação ao modo como as crianças com mais de três anos compreendem o que ocorre ao seu redor.

A partir daí, começou a se aproximar dos estudos que tratavam da descrição da inteligência sensório-motora. Segundo Luque e Palacios (1995), até o aparecimento da linguagem, os bebês relacionam-se com o mundo através das sensações/sentidos e da ação/exploração motora, estabelecendo relações progressivas entre os objetos e os atos que realizam. Desenvolvem, gradualmente, a intencionalidade de suas ações, coordenando seus esquemas de ação. Interagem pelos sentidos, a partir do tato, da visão, da audição e do paladar. Levam objetos à boca e assim experimentam sensações em relação à temperatura, densidade, textura, sabores dos objetos, estabelecendo relações com e entre eles. Relações essas que são pautadas pelas circunstâncias, pelo prazer e desprazer que o objeto causa naquele momento.

\begin{abstract}
O período sensório motor caracteriza-se pela construção de esquemas de ação que possibilitam à criança assimilar objetos e pessoas, caracteriza-se por uma inteligência prática, que coordena no plano da ação os esquemas que a criança utiliza. A criança vai pouco a pouco diferenciar e integrar os esquemas de ação entre si, ao mesmo tempo que se separa enquanto sujeito, dos objetos, podendo, por isso mesmo, interagir de forma mais complexa com eles. (MACEDO, s/d.).
\end{abstract}

A repetição das ações é muito importante para os bebês, pois a partir dela conhecem a regularidade dos objetos e fazem seu reconhecimento sensorial. Ao levar repetidamente objetos à boca, descobrem o que é “chupável” e o que não é, o que é áspero, macio, rígido ou poroso. Ao balançar, descobrem o que faz barulho, o que não faz, o que produz vento, o que não produz. Com isso, vão organizando, classificando e categorizando os sentidos e os objetos.

A boca é o local de maior sensorialidade, por onde começam suas primeiras explorações, inicialmente como ato reflexo de sucção, mas que progressivamente tornase um esquema que é aperfeiçoado pelo bebê, que passa a controlar quando suga para deglutir (ao mamar) e quando suga por sugar, sem que haja a deglutição. Assim, levar objetos à boca, é um ato necessário para ativar novos conhecimentos.

À medida que vai crescendo, o bebê conquista novos movimentos e maior controle motor de suas ações. As mãos tornam-se fontes necessárias para acesso aos objetos, coisas que são agarradas ao acaso, por movimentos aleatórios, passam a ser buscadas intencionalmente por ele. Os objetos que sumiam ao saírem de seu campo visual, passam 
a ser intencionalmente procurados, pois o bebê compreende que continuam existindo longe de si.

Ao conseguir sentar-se sem apoio, o bebê ganha uma nova perspectiva, seu campo visual torna-se mais amplo, as dimensões dos espaços onde se encontram se dilatam. Objetos que sumiam do campo visual, agora podem ser vistos à distância. A força da gravidade começa a ser percebida quando objetos caem das mãos, provocando barulhos e jogar objetos ao chão torna-se um jogo instigante na busca de regularidades sobre os diferentes barulhos que fazem ao cair. Torna-se possível observar a movimentação das demais crianças e dos adultos que estão à sua volta. Os gestos ficam cada vez mais intencionais e, pouco a pouco, os objetos ganham novas categorias: alguns servem para acomodar outros dentro de si (cestos, bacias e caixas); outros são empilháveis; outros se encaixam e, assim por diante.

Ao engatinhar, os bebês alcançam o que estava distante, passam a ter maior controle sobre onde desejam estar e fazem descobertas sobre a topologia dos lugares que podem transitar. Gradualmente, colocam-se de pé e ganham nova amplitude em seu campo visual, passam a enfrentar o desequilíbrio para conseguirem o equilíbrio sob os dois pés. Ao conseguirem andar sem apoio, buscam novas conquistas motoras, que se seguirão por toda a vida, mesmo que não sejam tão valorizadas como o andar!

A movimentação é, desta forma, fonte de acesso ao conhecimento. As novas posturas trazem possibilidades diferenciadas de explorar e descobrir o que ocorre ao seu redor. Ao longo do primeiro ano de vida, o bebê vai descobrindo e coordenando as partes de seu corpo, num esforço contínuo que favorece ao mesmo tempo descobertas sobre novas formas de se movimentar, maior controle motor e diferentes possibilidade de se conectar com os objetos que encontra pelo ambiente.

Segundo Trindade (2003), a expressão corporal é o vocabulário que o bebê utiliza para comunicar seus estados interiores, seus desejos e necessidades. Quando seu corpo está agrupado, com o tônus leve, numa movimentação organizada, ele expressa conforto, segurança, desejo de conhecer o que está ao seu redor. Quando o corpo está crispado, com tônus tenso e com movimentação irregular, evidencia-se seu desconforto, do mesmo modo como quando é colocado em uma postura que ocasione seu desequilíbrio.

A imitação é, também, uma forma de experimentar movimentos, ações e fazer descobertas sobre a funcionalidade dos objetos. Na relação com outros bebês, crianças e 
adultos, o bebê experimenta gestos e ações que observa nos demais: ora se apropriando de alguns, ora rejeitando-os.

Para além das conquistas motoras, os bebês estão imersos num ambiente de linguagens e sua comunicação ocorre pela ação e por formas não verbais que expressam seus estados emocionais. As feições, gestos, sons, sorrisos, choros, olhares e balbucios indicam seus desejos e necessidades. No relacionamento adulto-criança, aparecem jogos como o de cadê-achou, que se constituem por turnos de perguntas, silêncios e respostas que são muito significativos para a linguagem que está por vir.

A fala dos adultos embebe o ambiente de sonoridades e, a depender de suas qualidades musicais, podem indicar interesse, afeto e consideração pelas crianças, ou seu contrário. Mesmo antes de falar, os bebês indicam compreensão ao que lhes é comunicado. Realizam ações solicitadas, dirigem o olhar ao que o adulto mostra e comunicam seus interesses de diferentes modos. Com o aparecimento da linguagem, os bebês começam operar pela função simbólica e passam a ter a capacidade de representar pela fala o que pensam, tornando presente o que está ausente.

Segundo Luque e Palacios (1995), os êxitos mais destacados do período sensório motor descritos por Piaget são o estabelecimento da conduta intencional, a construção do conceito de objeto permanente, a construção das primeiras representações e o acesso à função simbólica.

Conhecer como se organiza a inteligência sensório-motora, auxiliou a autora desta pesquisa a delinear propostas para as crianças de sua escola e a formular ações de formação com as educadoras de modo a ajudá-las a compreender e decodificar as relações estabelecidas pelos bebês e as crianças bem pequenas estabelecem entre si e com os contextos que são organizados para eles. A partir dos conceitos apresentados pelas teorias de desenvolvimento e pela singela aproximação com a epistemologia genética de Piaget, partiu-se em busca de ações que constituíssem e consolidassem uma prática pedagógica de qualidade voltada aos bem pequenos. Em seu percurso, entrou em contato com os conceitos da Abordagem Pikler e a partir daí, as interações entre o cuidar e o educar se tornaram mais evidentes e vinculadas. 


\section{Contribuições da Abordagem Pikler}

Emmi Pikler (1902-1984) foi uma médica pediatra que atuou durante os primeiros 10 anos de sua carreira como médica de família. Ela criou um método próprio de trabalhar com as famílias, "se empenhava em ajudar os pais jovens a assegurar a saúde de seus filhos no dia a dia"». (SZANTO-FEDER, 2014. p. 20). Considerava as crianças como sujeitos completos, com competências e capacidades e, também, com necessidades e temores. Ao assumir a parceria nos cuidados com a saúde das crianças, firmava um compromisso com as famílias, no qual solicitava que permitissem que as crianças pudessem se movimentar livremente e não fossem colocadas em posturas que ainda não conseguiam se colocar autonomamente. Solicitava que tivessem uma atenção especial aos momentos de cuidados, de tal modo que se configurassem como "situações festivas, em que mãe e filho se sentissem felizes em conhecer-se e reconhecer-se, de apreciar-se, de intercambiar, de dialogar [...]" (SZANTO-FEDER, 2014. p21-22), além de garantirem boa alimentação e passeios ao ar livre. Em 1946, tornou-se diretora de um abrigo de crianças órfãs situado na rua Loczy em Budapeste, na Hungria.

Uma das primeiras ações de Pikler foi dispensar toda equipe que trabalhava no abrigo, por reconhecer que suas ações mecanizadas nos cuidados com as crianças eram atos de pequenas (mas, graves) violências praticadas contra elas. Em lugar de enfermeiras “especializadas”, optou por contratar pessoas jovens, com pouca experiência, mas abertas a aprender maneiras gentis de interagir com as crianças.

Partia do princípio de que as crianças necessitavam de condições ótimas para que pudessem se desenvolver bem e tivessem seu bem-estar físico e emocional garantidos. Tais condições se davam quando tinham a liberdade de movimento, podiam brincar por iniciativa própria e participavam/vivenciavam rotinas de cuidados zelosas, gentis e que as considerassem como sujeitos de ação, com iniciativas próprias desde o nascimento.

Emmi Pikler cuidou intensamente da formação das cuidadoras do abrigo. "Acreditava que o adulto devesse construir o mais alto grau de consciência sobre as suas intervenções”. (FOCHI, 2018, p.185). Considerava relevante que as crianças tivessem contato com um número reduzido de adultos nas situações de cuidados, pois assim poderiam criar uma relação recíproca, de respeito e de intimidade entre si. Instituiu

\footnotetext{
${ }^{8}$ Tradução livre do espanhol para o português da autora da dissertação
} 
protocolos para as diferentes situações de cuidados, pois considerava que ao serem abordadas por gestos gentis e semelhantes (previsíveis), as crianças desenvolveriam a confiança nos adultos e esses, por sua vez, estariam sempre atentos a elas nessas ocasiões. "A sua crença era a de que o respeito ao bebê se efetivava no grau e na qualidade da interação estabelecidos entre adulto-criança”. (FOCHI, 2018, p. 186).

Assim, na Abordagem Pikler as situações de cuidados e de atenção pessoal devem se constituir como momentos em que os olhares, a amabilidade, as palavras e mãos gentis entram em ação, a fim de proporcionar o bem-estar das crianças. Colocando em evidência o respeito ao ritmo de cada uma delas e a sua aceitação, garantindo sintonia e o ajuste sensitivo de suas ações. Como resultado dessas ações, constata-se que os cuidados assim praticados favorecem a saúde física e psíquica dos bebês e das crianças bem pequenas.

Durante as atividades de atenção pessoal num espaço de vida coletiva, o adulto precisa estar consciente de que as suas ações devem contribuir para que a criança tome consciência sobre o que está a acontecer, sinta-se segura e tranquila, estabeleça relações com a materialidade envolvida, de modo que ela possa ir gradativamente conseguindo executar por si própria. (FOCHI, 2018, p.192).

Outro princípio fundamental dessa abordagem é o valor da atividade autônoma e o movimento livre da criança. Pikler e seus colaboradores consideram que a criança nunca deve ser colocada numa postura a qual ela própria não consiga se colocar sozinha. A partir de sua movimentação, ela faz descobertas sobre seu entorno e sobre os objetos, sendo papel do adulto garantir tempo, espaço, material e segurança para suas explorações. A criança, na abordagem Pikler, é considerada um sujeito ativo e competente, sendo função dos adultos "criar as condições para que essa vida se expresse, que essas capacidades e competências que a criança possui se exerçam, se exercitem e se desenvolvam" (CHOKLER, 2010).

As intervenções dos adultos devem ser as menores possíveis, preferencialmente quando notam que a criança está em perigo ou necessitando de auxílio para voltar à sensação de bem-estar. O oferecimento de brinquedos, conversas e felicitações são consideradas ações que podem desviar a atenção das crianças sobre suas descobertas.

A observação dos bebês é primordial para que os adultos organizem os espaços e materiais que serão disponibilizados a eles, para que fomentem e intensifiquem suas descobertas. Há crianças que se encantam por ver o mundo entre as tramas de cestos, peneiras, ou escorredores de macarrão. Outras mantém-se atentas ao seu próprio corpo: 
mãos, pés e gestos. Tem também as que se interessam pelos sons do ambiente, outras que observam os movimentos dos elementos da natureza, como uma folha voando ao vento. Como afirmam Tardos e Szanto-Feder (2011, p. 46), "sua atenção e seu interesse se organizam no ritmo exato de sua maturidade, no nível que corresponde ao estágio de seu desenvolvimento".

A liberdade de movimentos possibilita que a criança experimente posturas e gestos de modo amplo e prazeroso e, ao mesmo tempo, oferece-lhe a segurança de retornar a uma postura a qual já está mais habituada. "Os movimentos e suas posições lhe são de utilidade para construir um esquema corporal correto, e os seus deslocamentos são importantes para estruturar ativamente a sua percepção de espaço.” (TARDOS e SZANTO-FEDER, 2011, p. 50).

\section{Estabelecendo um Diálogo entre a Inteligência Sensório-Motora e a Abordagem Pikler a partir do Registro de uma Educadora.}

\footnotetext{
Na vida de um bebê $[\ldots]$ o que domina são os aspectos repetitivos da cotidianidade, esses momentos em que não ocorre nada especial, nem relevante, nem sobressalente, mas só os fatos cotidianos. Isso é o que tornam importantes esses momentos, horas e dias: o objetivo dos que se ocupam do bebê é também enriquecê-los e torná-los significativos. (SZANTO-FEDER, 2014, p. 75).
}

A presença interessada do adulto faz com que a criança se ocupe de si mesma, de suas sensações, interesses, movimentos e das possibilidades que os objetos (brinquedos, utensílios e elementos da natureza) apresentam para si.

A partir do entendimento de como bebês e crianças pequenas pensam, é possível realizar uma leitura ampla de suas ações, de forma menos centrada no adulto e menos polarizada entre o que é certo ou errado, do que pode ou não pode, como se houvesse sempre dualidades opostas. Ao observar os bebês em ação, é possível descobrir seus interesses e com isso, oferecer novas possibilidades e contextos às suas pesquisas.

$\mathrm{Na}$ Educação Infantil, as educadoras assumem junto com as famílias o papel de apresentar-lhes o mundo e com isso deve ser zelosa em sua tarefa. Considerando, desde o princípio, seu ponto de vista e como se relacionam com os outros, com os objetos e com os ambientes. Para isso, deve-se cuidar de como receber essas crianças e do que será proposto a elas. Dando-lhes tempo para que se ambientem e se envolvam com o que ocorre em seu entorno. Torna-se necessário que as educadoras depreendam sentidos a 
alguns detalhes que interessam as crianças e, ao mesmo tempo, busquem maneiras de fomentar suas inquietações.

A partir do relato de Márcia de Oliveira, educadora da turma dos bebês do espaço ekoa, reflete-se sobre as intervenções realizadas e outras possíveis que abasteceram e poderiam abastecer as perguntas que essa bebê se fez.

Primeiro, vamos à situação:

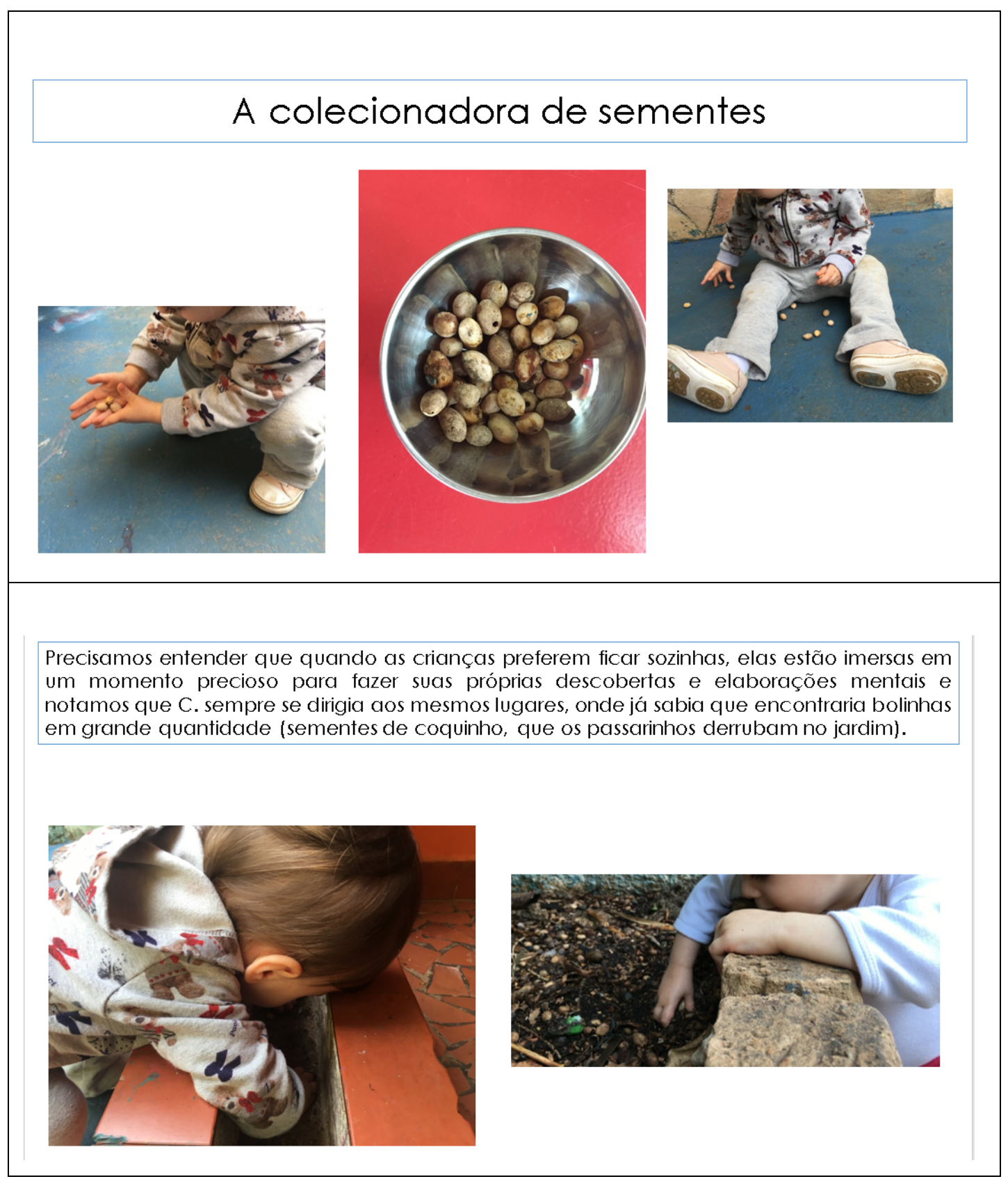




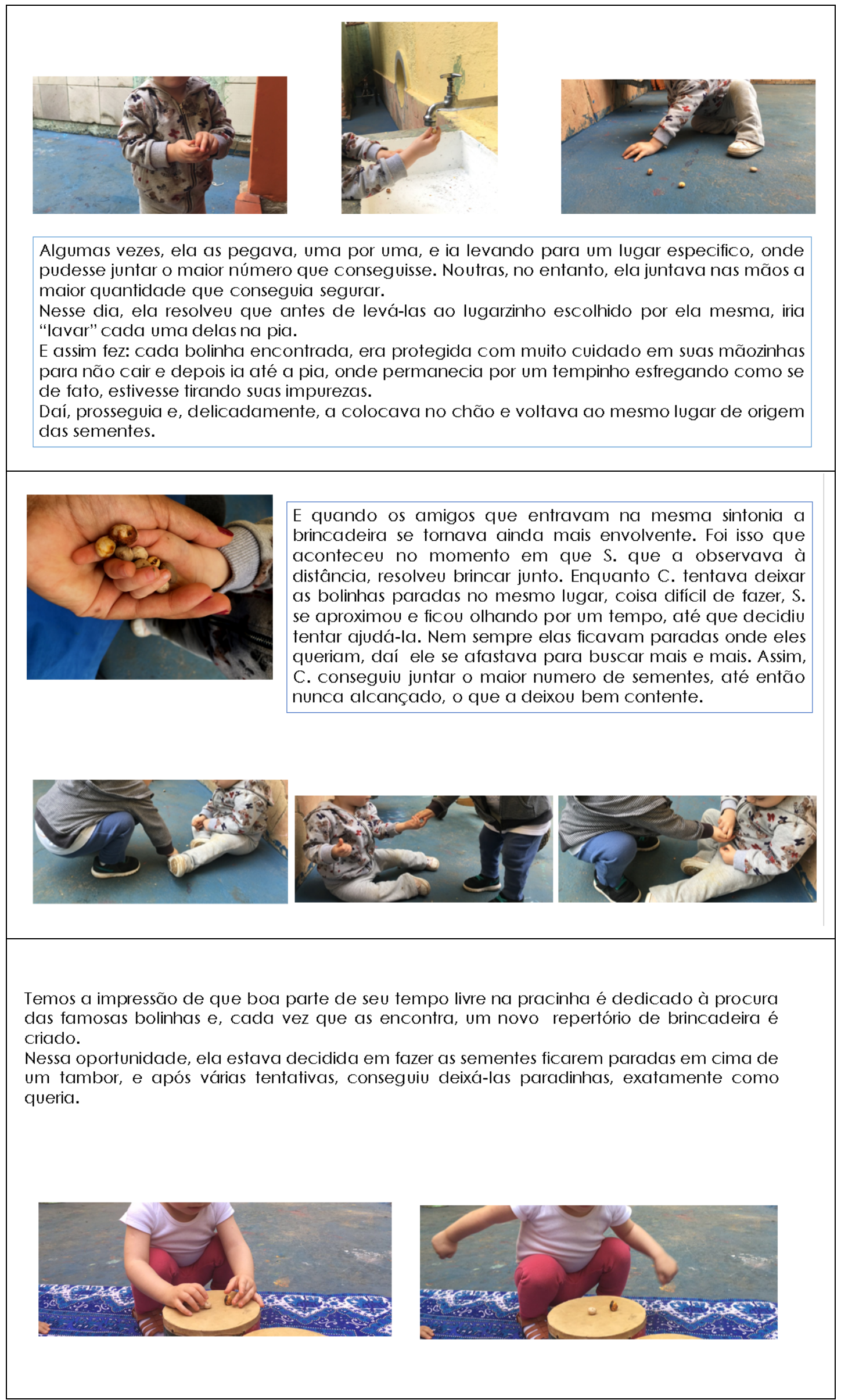




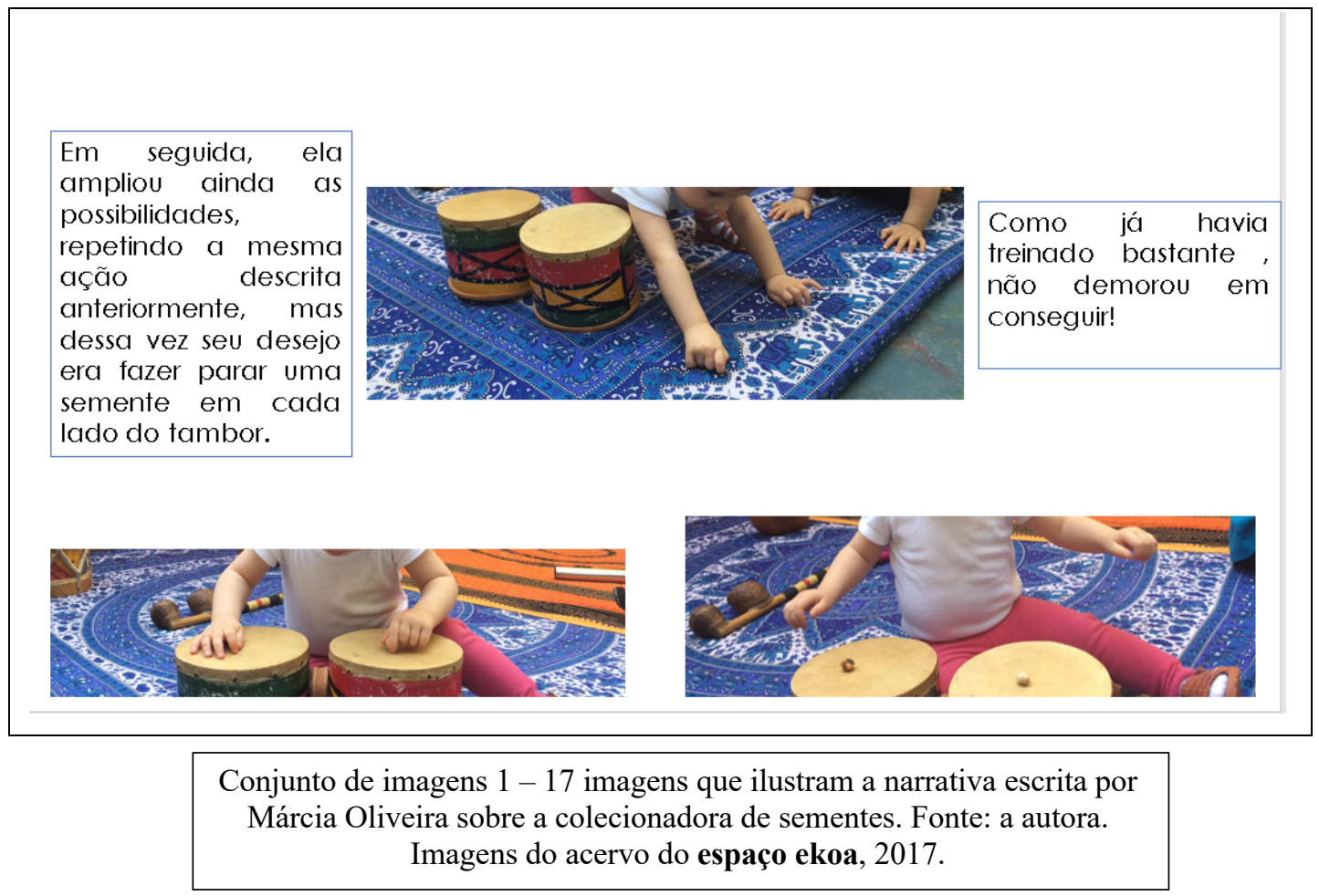

O que é possível ver?

Observa-se uma boa ilustração de que um evento trivial do cotidiano é carregado de sentido e significado para uma criança e que ao ser visibilizado pela educadora ganha uma notabilidade. Além disso, pela documentação do brincar, comunica a outros adultos, familiares e demais educadoras, o que move a atenção da criança.

Vê-se uma criança que evidencia seu interesse, que já se apropriou do espaço de brincadeira de tal forma que já sabe onde encontrar elementos que atraem sua atenção. Percebe-se uma criança interessada em coletar pequenos elementos e investiga sobre suas propriedades. Num momento, busca formas de acomodá-los em suas mãozinhas e imita ações dos adultos ao lavar uma a uma das sementes. Depois, tenta entender como mantêlas próximas de si, sem que rolem. Então, acompanhada de outra criança consegue criar maneiras de coletá-las em maior quantidade e de equilibrá-las. Por fim, é possível ver que a repetição da brincadeira com esse mesmo elemento vai se intensificando e ganhando nova intencionalidade e que a busca do equilíbrio era algo que mobilizava suas ações e pensamentos.

Registre-se que a educadora que já conhece essa criança e por isso mesmo a observa e faz registros de suas ações. Que consegue ler seus gestos e deslocamentos, valorizando-os e dando espaço para que explore os espaços e faça descobertas sobre o 
que desperta seu interesse. Sem interromper sua ação com falas, ajustes ou proposições, se faz presente e evidencia que acompanha e que valoriza suas investigações.

A partir dessa observação, a educadora poderia ter criado outros contextos e ter selecionado outros materiais para fomentar as pesquisas dessa criança, poderia disponibilizar cestos e potes em diferentes tamanhos para que ela pudesse acomodar as sementes coletadas. Poderia disponibilizar tábuas e outras superfícies para que pudesse experimentar se conseguiria ou não equilibrar as pequenas sementes.

Mas, para além de intervenções, a educadora consegue ter evidências que ao brincar com objetos as crianças se colocam perguntas sobre alguns de seus atributos (peso, forma e tamanho), assim como experienciam as interferências da gravidade e da topologia das superfícies que favorecem que as pequenas sementes se mantenham equilibradas ou que rolem para longe de si.

Enfim, nessa mini-história, é possível ver uma criança em seu esforço de conhecer o que está ao seu redor, alguém que busca assimilar as propriedades do objeto que chama sua atenção e, pouco a pouco, vai acomodando e modificando suas ações para compreender ainda mais suas propriedades e possibilidades, colocando-se novas perguntas e procurando respondê-las pelas suas ações e interações com o próprio objeto, com o ambiente e com as pessoas que se aproximam de si.

Percebe-se ainda uma educadora que controla seu ímpeto de ensinar e resolver os problemas enfrentados pela criança, dando-lhe espaço para experimentar e comprovar suas descobertas, validando os percursos escolhidos e dando oportunidade para o reencontro contínuo da criança com aquilo que desperta seu interesse.

Num olhar mais ampliado, torna visível e traz concretude a infinidade de aprendizagens que uma situação frívola do cotidiano pode oferecer tanto às crianças como às educadoras, principalmente se estiverem abastecidas pelas lentes e sensores das abordagens teóricas destacadas. 


\section{CAPÍTULO 4. UM OLHAR PARA AS SINGULARIDADES DAS CRIANÇAS NO COTIDIANO DOS ESPAÇOS EDUCATIVOS}

Quando se começa a trabalhar com as crianças pequenas, a princípio pensa-se que são as mães e os pais que apresentam seus filhos. Isto não deixa de ser verdade, mas essa apresentação não é feita apenas por palavras, são os gestos, modo como seguram a criança, as roupas e acessórios que a criança veste, a mochila e como ela é organizada que nos contam como a criança é vista por seus pais 9 . Mas, à medida que se atua com essa faixa etária, dá-se conta de que há informações sutis, apresentadas principalmente pelos sinais corporais da criança, que muitas vezes não são percebidos pela própria família, que certifica ou contradiz aquilo que suas mães/pais dizem sobre elas.

À medida que se consolida o olhar e escuta atenta para quem é essa criança e o que ela nos diz sobre si, tanto a partir daquilo que seus familiares dizem, como em seus atos pessoais, a ida à escola/creche pode contribuir para que ela se apresente de modo amplo e singular, e encontre novas maneiras de se expressar e se colocar em suas relações pessoais. Em seu texto, A mãe, a professora e as necessidades da criança, Winnicott(1982) considera que a escola maternal contribui para a construção da identidade e autonomia e favorece sua higiene mental, uma vez que tira da criança a responsabilidade por ter que corresponder às expectativas que as mães e pais depositam nela. Num espaço educativo de qualidade, mais conhecido como creche ou berçário, a criança bem pequena tem a oportunidade de ser mais uma, isto é, de fazer parte de um grupo e vivenciar rotinas pensadas e dirigidas a esse coletivo, porém tendo sua singularidade respeitada.

Os primeiros contatos das educadoras com as crianças ocorrem durante o período de adaptação, quando algum familiar de referência participa e auxilia a criança sentir-se segura sob os cuidados de uma nova pessoa; num novo lugar, diferente de sua casa que, dia a dia, vai se tornando conhecido.

Nesse início, as recusas, estranhamentos e choros são comuns, assim como o aparecimento de dúvidas e inseguranças por parte da pessoa responsável sobre a continuidade desse processo de separação, cabendo às educadoras e à instituição assegurar-lhes que tais reações são esperadas e representam maneiras das crianças nos dizerem sobre si e estabelecerem limites sobre o modo como as aproximações poderão

9. No texto, A observação de bebês em uma situação estabelecida, Winnicott (1941) descreve como estabelecia seu primeiro contato com um bebê e sua família ao observar o modo como era conduzido da sala de espera até sua mesa, no consultório. 
ocorrer. Exemplificando, há crianças que precisam que seus familiares estejam em seu campo visual para que consigam interessar-se pelo que lhes é apresentado; outras choram ao estarem em salas fechadas, mas alegram-se quando brincam ao ar livre; há aquelas que precisam de muitos acessórios para sentirem-se seguras (chupetas, paninhos, mochilas e brinquedos), entre outras reações possíveis. A dubiedade é inerente ao processo de adaptação. Num mesmo dia, ocorrem avanços e retrocessos na segurança apresentada tanto pelas crianças, como por suas mães, pais ou avós; cabendo às educadoras e instituições o suporte (e a possibilidade de suportar) para que progressivamente os vínculos de confiança se estabeleçam.

Após esse período, normalmente, as crianças (e seus familiares) começam aceitar melhor a separação, dando início à efetiva participação na rotina da instituição. Nessa ocasião, suas reações também variam. Algumas crianças prontamente se inserem nas diferentes propostas e, outras parecem alheias ao que ocorre ao seu redor - como se estivessem apenas esperando pela hora de ir embora. Esse período precisa ser muito bem cuidado pela educadora, a partir do estabelecimento de uma relação próxima e pessoal com cada uma das crianças, a fim de conhecer suas preferências, desejos e receios.

A educadora de bebês e crianças pequenas precisa aprender a decodificar o que eles explicitam a partir de movimentos sutis, olhares, balbucios e choros; traduzindo em palavras e ações o que estão compreendendo. Para tanto, ela deve buscar em seu próprio corpo, tom/melodia de voz e gestos, ações que favoreçam a boa interação com as crianças. "Mas para que tudo isto se torne sensível, é necessária uma reflexão ininterrupta, um pensamento vivo que dê sentido ao que fazemos com a criança". (CRESPIN, 2016, p.29).

É nesse ponto que os conceitos relativos à constituição de sujeito, subjetividade e intersubjetividade merecem uma atenção especial da Pedagogia dirigida aos bebês e crianças pequenas. É comum que em contextos educativos as crianças sejam tratadas no plural, como um coletivo comum, mas quando nos aproximamos delas vemos que cada uma é única, têm sua própria história pessoal, seu modo de lidar com o novo que se apresenta. Algo que provoca alegria e prazer para uma criança, pode gerar desconforto e insegurança para outra.

Se no capítulo anterior ocorreu a tentativa de compreensão sobre como a criança assimila o mundo ao seu redor, como se relaciona com os objetos, espaços e materiais, neste capítulo procura-se colher pistas sobre quem é essa criança, o que sente, como compreende seu lugar no mundo e como se dá a construção do sentimento de pertencimento quando se vê frente ao convívio coletivo. 
Até o início de sua vida escolar, os contextos de convívio costumam ser mais íntimos e pessoais. O bebê que nasce, ocupa um lugar especial em sua família, tem um nome especialmente escolhido que lhe traz uma identidade própria, a fim de distingui-lo de todos os homônimos que possa vir a conhecer. É alguém com passado, presente e futuro imaginados. São indivíduos com histórias pessoais únicas, que podem ser muito boas ou extremamente turbulentas a depender de múltiplos fatores que não fazem parte do escopo desta pesquisa e quando chegam ao espaço educativo precisam construir uma nova forma de se ver no mundo, construir um novo papel e aprender a "ser mais um" dentro de um coletivo.

Segundo Victor Guerra (2009), o bebê está desde o nascimento em estreita relação com o outro. Suas percepções e seu mundo interior são mais bem percebidos na interação, quando aquilo que o mobiliza é traduzido pelo adulto cuidador (a mãe, em especial) como sendo fome, sono, fralda cheia, dor ou graça. Dessa maneira, se constitui a intersubjetividade: num diálogo entre a subjetividade nascente do bebê e a subjetividade constituída e transformável da mãe e do ambiente.

Reconhecer cada criança em sua singularidade é fundamental para dar-lhe espaço dentro do novo ambiente coletivo. Para isso, a educadora deve observá-la para colher informações sobre o que atrai sua atenção, o que a incomoda, quais objetos favorecem a elaboração de brincadeiras, como prefere que seu corpo seja tocado nos momentos de banho, troca e sono, qual a temperatura dos alimentos que mais a agrada, numa lista que nunca se esgota, pois engloba uma pessoa em sua totalidade. Como descreve Carvalho (2001, p.3):

\begin{abstract}
[...], ao nos referirmos ao bebê, com a perspectiva de pensar neste processo de constituição do sujeito, incluímos tanto os aspectos de condições ambientais e orgânicas - constituição e funcionamento físico e fisiológico -, quanto os aspectos simbólicos que o determinam: o lugar que ocupa na família, os mitos familiares, as ações realizadas em função do bebê, o que se fala dele, os sujeitos desses discursos, os desdobramentos desses campos discursivos a partir dos primeiros contatos, enfim, o que se pode falar a respeito dele e por ele, incluindo real, imaginário e simbólico.
\end{abstract}

A educadora tem um grande desafio, pois deve conseguir coordenar suas primeiras percepções sobre cada criança por intermédio de seus conhecimentos sobre crianças. Nesse ponto, é preciso um cuidado com o como as questões que se apresentam e como serão tratadas, pois é tênue a linha divisória entre as ações que buscam apenas distrair as crianças de seu choro e angústias, das que efetivamente respeitam seus sentimentos e incluem os saberes sobre a infância. 
Esses saberes visam garantir que ao longo do período em que ficarão distantes de seus familiares (entre 04 e 12 horas de um dia, a depender da necessidade da família), as crianças serão apresentadas a elementos significativos da cultura; estabelecerão relações com outras pessoas, adultos e crianças, que não seus familiares, num convívio harmonioso (com os conflitos inerentes) e terão seu dia permeado por vivências desafiadoras com momentos dedicados ao movimento, brincadeira e à partilha de situações de linguagem, numa rotina planejada e enriquecida. Enfim, como assinala Marin (2018, p. 136), “oferecer um pano de fundo rítmico, previsível, de permanência, buscando garantir a continuidade para o sentimento de existir do bebê”.

Assim, cada uma das crianças deve ser considerada como sujeito único, que está se relacionando com outros e aprendendo a lidar com a divisão de espaços, materiais e atenção. No cotidiano das creches/berçários, as educadoras se deparam com situações que suscitam reflexão e cuidados para a garantia de sua segurança e bem-estar. Elas dedicam especial atenção ao que é dito em sua presença, pois é mais comum falar da criança do que falar com ela, num lapso que contradiz o que se coloca como objetivo em praticamente todos os projetos pedagógicos.

Dentro dos limites, as falhas e desencontros são contornados quando "tudo vai bem” com as crianças. Isto é, quando as famílias demonstram segurança e confiança em delegar seus(as) filhos(as) aos cuidados de terceiros; quando as próprias crianças se vinculam aos adultos, às outras crianças e às diferentes situações que lhes são propostas no cotidiano dos espaços educativos, e/ou quando as educadoras percebem que podem realizar seu trabalho profissional. A autora desta dissertação acredita que no trabalho com os bebês e as crianças pequenas, é preferível que as relações ocorram nessa tríade, criança, família, educadora, para que cada criança possa de fato se vincular e sentir-se segura quando está longe de seus familiares.

Considera-se, ao mesmo tempo, que é papel das creches e das educadoras a construção de um olhar sobre as demandas da criança e, consequentemente, de uma nova maneira de dirigir-se a ela. Um bom exemplo é esse outro relato da educadora do espaço ekoa, Márcia Oliveira, sobre uma menina de um ano e cinco meses, após um mês de seu início: 
"A pequena menina que outrora precisava de uma mão para ir e vir em segurança, passou a caminhar livremente, serena e curiosa pelos acontecimentos ao seu redor. Como no dia, em que ao ser convidada por mim para ir ao banheiro trocar a fralda, correu na minha frente para brincar com as poças de água da chuva, que havia cessado há poucos instantes.

Mantive distância, observando-a por um longo tempo, me sentindo

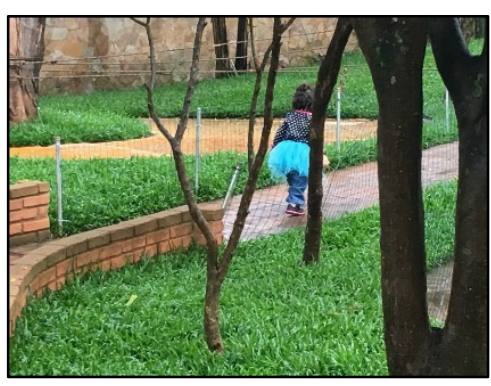
muito feliz em vê-la assim, tão à vontade por aqui.

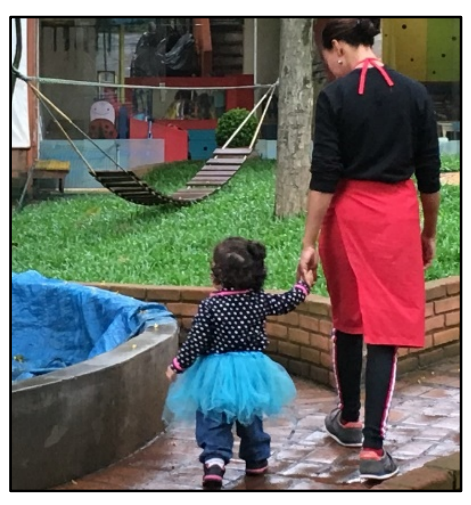

Após um longo período de contemplação, envolvimento e diversão, me aproximei e a relembrei para onde deveríamos ir. Sorrindo e me olhando, timidamente, estendeu a mão e fomos caminhando devagar, para que ela pudesse continuar apreciando o chão molhado, as flores caídas, já que ainda estava evidente seu interesse.

São maneiras como essa, cercando-a de afeto, respeitando seu tempo e caminhando na mesma sintonia, que avançamos, dia após dia, mais um passo nessa relação."

Conjunto de imagens 2 - 02 imagens que ilustram a mini-história escrita por Márcia Oliveira sobre uma troca de fraldas. Imagens do acervo do espaço ekoa 2018. Fonte a autora.

Aqui vê-se a delicadeza e respeito em relação a essa criança. Um percurso que poderia ter sido interrompido em função de valores externos à criança, por uma eventual pressa da educadora, ou mesmo por considerar inadequado que uma criança pisoteie numa poça de água, foi valorizado e visto como uma conquista. A educadora reconheceu nessa ação um marco na segurança da criança em estar no espaço escolar, como se naquele momento e daquela maneira ela dissesse "agora eu reconheço este lugar como meu, posso correr, brincar, estar aqui e dou conta de estar distante de minha mãe, porque me abasteço de muitas vivências e me sinto cuidada, reconhecida e respeitada por esta pessoa que fala comigo de modo tão gentil!"”.

\section{Lidando com o Choro}

E desde esse instante, que chamamos de 'encontro inaugural', esse grito não é mais um ruído, é um apelo, e a partir daí, antes de qualquer linguagem propriamente dita, o bebê fala, o bebê é promovido ao estatuto de sujeito falante. (CRESPIN, 2004. p.26). 
No dia a dia dos espaços educativos, o choro das crianças costuma ser algo recorrente, mas os motivos dos choros variam muito. Tem criança que chora por estranhamento, outra por desconforto físico e outra, ainda, por saudade de seus familiares. Tem choro decorrente de disputa por brinquedo, choro para receber colo e atenção, choro por recusa diante de algo que é proposto, numa grande lista que não se esgota. Desse modo, é desejável que a educadora aprenda a decodificar o que as crianças tentam comunicar ao chorar e deve buscar maneiras de acolher e traduzir o que estão lhes mostrando.

Há crianças que apresentam, com certa recorrência, crises de choro bastante intensas, longas e que iniciam sem um motivo evidente. É possível perceber certa regularidade nesse tipo de manifestação, pois em geral estão ligadas a algum desconforto físico, como sono, sensação de torpor ao despertar ou fome intensa. Esse tipo de reação, também costuma ocorrer antes ou após a criança receber algum cuidado físico que pode ser mais invasivo, como banho, troca de fralda ou de roupa.

Há situações em que a recusa e choro intensos são desencadeados no meio de um processo de cuidado, quando a educadora está tirando a roupa da criança e ela, ao perceber que isto está acontecendo, começa a se debater de tal maneira que torna difícil tanto tirar como recolocar a roupa.

Frente às situações como essas, as educadoras ficam sem saber como agir e comumente começam a conversar entre si, sem levar em consideração que a criança está por perto. Relatam o que aconteceu, de que maneira a criança começou a chorar, falam o que já tentaram fazer para acalmá-la, mas quase não dirigem a palavra à criança que está diante de si. Somente quando a criança para de chorar, que voltam a dirigir-lhe a palavra.

Lidar com reações como essas não é nada fácil, porém não é possível lidar com o choro de qualquer criança como algo naturalizado, ou referir-se à criança como "ela só chora mesmo, mas logo passa". Uma boa maneira de cuidar disso, é fazer com que a criança perceba que seu choro está sendo escutado e que mesmo que ela não consiga explicitar o que lhe causa incômodo, os adultos presentes estão disponíveis para ajudá-la. Para além das crianças, reconhecer a necessidade de escuta do choro é importante também para as educadoras, pois explicita o papel da linguagem, nesse caso, a linguagem não verbal, como fundamental para a construção de sentido ao que é realizado com as crianças. Pode ser que a criança ainda chore por um período, até que consiga voltar a calma e aceitar o acolhimento, mas, mesmo assim, faz muita diferença ela perceber que 
há um adulto disponível e conectado a ela e não alguém impaciente que finge ignorar seu choro.

A depender do modo como acolhe ou nega-se acolhimento à criança, quando elas sinalizam que algo não caminha tão bem (ou por uma indisposição temporária ou por motivos recorrentes que demandam uma atenção ainda maior), a educadora favorece ou impede seu processo de individuação e o reconhecimento e nomeação daquilo que a perturba.

A autora desta pesquisa acredita que é necessário dedicar tempo para parar e ouvir o que a criança tem a dizer e legitimar sua recusa, mesmo fazendo valer a regra contrária àquilo que ela deseja. Tomando cuidado para que a regra não seja colocada de forma embrutecida, "a regra pela regra" e a criança tenha que se submeter de forma passiva ao que lhe é imposto.

Infelizmente, há um discurso recorrente que considera as ações de acolhimento como sinônimo de mimar uma criança, mas isto é diferente, pois mimar é resolver o problema sob a ótica do adulto ou porque ele considera a criança frágil para suportar uma negativa ou, ainda, para ter "menos trabalho" com ela. Contudo, o acolhimento deve ser tratado como um princípio fundamental do trabalho com essa faixa etária, pois é uma forma de mostrar-lhes que são bem-vindas, que serão cuidadas e reconhecidas nesse novo espaço diferente do de sua casa. O acolhimento se dá na escuta e na tradução do que ocorre, ao que é esperado que as crianças realizem e no encorajamento de suas ações. Deve ser uma atitude permanente.

É papel da educação das crianças pequenas promover um dia (e todos os dias) melhor(es) para todas as pessoas envolvidas e são nas ações de cuidados, quando as educadoras se colocam efetivamente em relação com cada uma das crianças, que isto acontece e ambas as partes se beneficiam emocionalmente quando esses encontros de qualidade acontecem.

\section{Lidando com as Mordidas}

Quem trabalha com crianças pequenas costuma ter que lidar com certa frequência com crianças que mordem (a si mesmas, as outras e até os adultos) e nem sempre é possível resolver de modo rápido e tranquilo as questões que envolvem esse tipo ação. As pressões são muitas, vão desde a ansiedade que as famílias apresentam (quando os filhos mordem e quando recebem as mordidas); como as dificuldades para que as 
educadoras atuem em parceria; além do problema em si, a fim de evitar que ocorram novas mordidas.

Em geral, o foco de ação dirige-se ao como resolver essas situações e ao que deve ser feito para que uma criança que morde, deixe de morder. Entretanto, é mais importante descobrir o que a mobiliza a morder e a partir daí, pode-se criar contextos que alterem a sintonia e contenham seus impulsos.

Existem diferentes motivos que favorecem as mordidas e podem-se colher indícios sobre o que desencadeiam as mordidas, realizando observações das crianças individualmente e avaliando a atmosfera e tensões, relacionadas ao convívio no espaço coletivo.

Desde o nascimento, as crianças estão imersas num ambiente de linguagem e comunicação. Recebem de seus cuidadores olhares, palavras e gestos que informam sobre sua rotina e lhes apresentam o mundo ao redor. A criança, por sua vez, de modo incipiente, comunica sobre seus desejos e interesses e, gradualmente, percebe que a partir de determinadas ações suas, recebe uma resposta semelhante de seus cuidadores e com isso, passa a buscar essa regularidade. Porém, nem sempre conseguem se fazer entender e isto costuma provocar certa frustração e um modo de sinalizar esse incômodo é mordendo alguém que esteja por perto.

Costumeiramente, as mordidas ocorrem entre crianças de um a três anos de idade, período em que a boca atua como um potente local de conhecimento do mundo, quando a maior parte dos objetos são primeiramente conduzidos à ela. Pela boca, percebem suas texturas, temperaturas, densidades. Quando começam a conviver com outras crianças, o desejo por conhecê-las é grande e muitas vezes, nada como levá-las à boca, numa interação destituída de intencionalidade de causar dor.

Quando isso acontece, a criança que recebe a mordida, costuma reagir chorando, os adultos que estão por perto falam de modo ritmado e dirigem um tom de voz mais elevado e um olhar firme à criança que mordeu. Toda essa resposta do ambiente pode parecer muito interessante para a criança que passa, então, a repetir a mesma ação, a fim e verificar se a receberá sempre do mesmo modo.

Às vezes, a própria sensibilidade decorrente do nascimento dos dentes e do desejo de levar tudo o que há pela frente à boca, faz com que determinadas crianças acabem, recorrentemente, mordendo seus colegas.

Ao observar alguns contextos em que as mordidas acontecem, a educadora pode notar que situações que provocam maior excitação favorece que a criança "queira 
devorar" o que estiver por perto. Também é comum, que crianças que recebem muita atenção dos adultos, por serem muito frágeis ou graciosas, costumam ser alvos interessantes de mordedores, como se após a mordida aquilo que agrada tanto aos adultos fosse transferido a quem a mordeu.

Mordidas ocorrem também quando uma criança sinaliza desejo de se comunicar pela fala, mas ainda não consegue, tal como Françoise Dolto (2007, p. 175) explicita como "uma agressividade da impotência para falar".

Durante o período de adaptação ou no retorno de um período de férias e entrada em uma nova turma, algumas crianças manifestam estranhamento com a nova rotina, novos colegas e novas educadoras. No momento da despedida, é comum que chorem ou resistam em permanecer sob os cuidados de suas educadoras, causando também certa insegurança em seus pais e mães. Para amenizar os estranhamentos, é recomendável que a rotina $\mathrm{e}$ as propostas dirigidas às crianças se assemelhem às que aconteciam com a educadora anterior e nesse período possam usar com maior frequência chupetas, paninhos e demais objetos de apego. O que para algumas famílias nem sempre é bem aceito, pois acreditam que isso poderá interferir no grau de dependência com tais objetos também em suas casas.

Considera-se interessante destacar aqui a necessidade de escuta e interlocução das educadoras com as famílias. Se por um lado, é relevante respeitar seus pontos de vista, cabe buscar formas de fazê-las compreender que para as crianças as transições podem ser difíceis e, se tiverem a oportunidade de prever o que irá acontecer com elas e ainda puderem contar com elementos que lhes trazem segurança, terão seu bem-estar garantido nesse instante. Deve-se considerar seu uso será transitório e pontual e, assim que voltarem à sensação de segurança no espaço educativo, vão conseguir se abastecer das novas vivências que constituirão suas rotinas diárias, deixando tais objetos de lado.

Não costuma ser um período tranquilo para ninguém, havendo a necessidade de muitos ajustes e acordos a fim de garantir o bem-estar das crianças e amenizar a preocupação das famílias sobre seus possíveis retrocessos.

No decorrer dos anos, na direção de sua escola, a autora já vivenciou situações em que determinadas famílias decidiram, no período de férias, restringir o uso das chupetas e quando as crianças retornavam ao ambiente coletivo esperavam que não usassem mais. O mesmo acontecia com paninhos e demais objetos de apego. Ocorre, porém, que esses acessórios atuam como facilitadores na adaptação e acolhimento das 
crianças no espaço educativo e, para algumas delas, a restrição fazia com que demonstrassem seu desejo pelo uso através da mordida.

Essa restrição nos faz pensar sobre a importância dos objetos transicionais (Winnicott, 1975) para a garantia do bem-estar e segurança emocional das crianças e sobre os limites e possibilidades de interlocução entre educadoras e famílias para que as necessidades das crianças sejam consideradas. A mordida aparece como uma potente forma de comunicação sobre aquilo que falta a algumas crianças, como nos diz Winnicott (1975, p.29) "essencial a tudo isso, é a continuidade (no tempo) do ambiente emocional externo e de elementos específicos, tais como o objeto ou objetos transicionais".

\section{Crianças que Pouco Brincam}

Há crianças que apresentam uma forma peculiar de se relacionar com as propostas, com os colegas e com suas educadoras. Durante o período de adaptação, é comum existirem crianças que resistem ao estabelecimento de contato, mantendo-se imóveis frente aos convites para a participação das mais variadas propostas. Às vezes, permanecem caladas, com olhares distantes, sinalizando ausência e expectativa de voltarem a se relacionar somente quando percebem o retorno de seus familiares.

Certa vez, tivemos no espaço ekoa, uma criança de dois anos, que permanecia imóvel ao lado de sua educadora durante toda a manhã e, poucas vezes, manifestava qualquer tipo de ação intencional de participação nas propostas. No final do período, quando sua mãe vinha buscá-la, ela sorria e como se quisesse contar o que os colegas tinham feito, circulava por todos os ambientes que tinha passado (na realidade tinha sido conduzida) ao longo da manhã. Em sua casa, ela cantava as cantigas que tinha ouvido e imitava alguns gestos de sua educadora, evidenciando o quanto estava absorvendo de sua nova vivência conosco.

Nesse caso, a recusa em participar das brincadeiras denotava uma forma de sinalizar que precisava de um tempo para se apresentar efetivamente e não como um sinal de recusa ou resistência em estar nesse ambiente coletivo. Para além disso, era uma maneira da criança explicitar que sentia a falta de sua mãe, como alguém que pudesse autorizá-la a estar ali integralmente.

Há crianças, entretanto, que chamam a atenção em função do comportamento que apresentam em diferentes situações ao longo do dia, quando, mesmo após o período de adaptação, pouco brincam ou participam das situações coletivas. Algumas 
permanecem alheias ou distantes e, outras apresentam ações desordenadas e pouco vinculadas aos contextos coletivos.

Há aquelas que costumam se colocar distantes do grupo, quase não fixam olhar e quando os adultos se aproximam não demonstram intenção de interagir. São crianças que costumam causar preocupação. As educadoras se esforçam em convocá-las a participar das situações planejadas ao grupo. Aproximam-se de modo sutil e pouco invasivo, dirigindo-lhes convites, estendendo as mãos, buscando seus olhares e esperando suas reações. Muitas vezes surpreendem-se com as mudanças que vão acontecendo, quando pouco a pouco, tornam-se mais receptivas à integração e participação nas situações coletivas. Quando os olhares perdidos, começam a se fixar e suas ações se tornam mais intencionais e organizadas.

Há crianças que nos intrigam e preocupam, pois mantém-se desconectadas e pouco mobilizadas à partilha de brincadeiras estruturadas. São crianças que ao encontrarem brinquedos e objetos dispostos em um ambiente, começam a lançá-los ao chão, nas vezes em que iniciam uma exploração de forma mais centrada, quando notam o olhar do adulto, voltam a se desorganizar, começam a correr, arremessam os brinquedos alternando entre momentos de construção com muitos de desorganização e destruição. Quando começam a se expressar pela linguagem oral, elegem palavras para falar e as repetem de modo silabado (LO-BO, VO-VÓ-Ó), sem que haja um contexto específico para enunciá-las.

Nas interações estabelecidas com essas crianças, é interessante que a educadora procure ampliar os tempos em que iniciam uma brincadeira, não valorizando suas ações destrutivas, reorganizando os materiais, tão logo sejam arremessados, chamando-as para ajudar. Com o tempo, percebe-se que costumam responder bem a esses chamados e conseguem envolver-se por mais tempo em brincadeiras focadas.

Quando falam, por exemplo sobre o "LO-BO" de modo silabado, a educadora pode iniciar uma narrativa, falar da história dos três porquinhos, perguntar sobre o que acontece e tentar ajudá-las a estabelecerem uma fala mais encadeada, mesmo que sejam marcadas prioritariamente por gestos e balbucios. A educadora pode criar uma narratividade conjunta, tal como Victor Guerra (2018, p. 185) descreve, na qual em conjunto com a criança torna o enredo repetido numa história mais encadeada e assim, é possível cocriar uma interação e troca mais intencionais a partir de um enredo que elas conhecem muito bem. 
Essas costumam ser crianças que causam preocupação, pois parece que algo que as impedem de relacionarem-se de forma mais profunda e intencional com adultos e crianças. Como assinala Victor Guerra (2018, p. 179), parece que "há uma disritmia no encontro intersubjetivo", com interações marcadas por comandos verbais e interações fechadas e poucas interações estabelecidas com perguntas ou respostas abertas e pelo inusitado, tão comuns nos relacionamentos íntimos.

Muitas vezes crianças que atuam desse modo até se interessam pelas brincadeiras propostas pelas educadoras, mas, ao mesmo tempo, apresentam limitação no envolvimento, principalmente quando percebem a alegria por alguma resposta mais interativa que tenham dado. Dão a impressão de que segundos antes de estabelecerem uma troca mais fluida e interativa nas brincadeiras, elas se distraem, dando a impressão de que agem intencionalmente, que não querem convocar o adulto para a brincadeira, deixando no ar de que algo deveria ser feito para que não "escape" tanto.

\section{Interligando as Análises e os Relatos}

Desde 2002, as educadoras do espaço ekoa foram orientadas a conversarem com os bebês e crianças pequenas, dirigindo-lhes o olhar, num tom de voz agradável. Isso se intensificou ao entrarem em contato com a Abordagem Pikler, com a importância do "manhês" de Marie Christine Laznik (2010) e da narratividade conjunta do psicanalista uruguaio Victor Guerra (2017).

Cada vez mais, a partir das leituras de autores da psicanálise, intensifica-se a ideia de que quando as crianças entram no campo da palavra e linguagem ocorre a consolidação dos relacionamentos interpessoais, o entendimento das demandas e dos desejos e com isso, dá-se humanidade e novos sentidos às relações estabelecidas entre as crianças e suas educadoras.

No cotidiano dos espaços educativos, ocorrem muitas situações de encontros/desencontros, trocas/rupturas, ritmos/percalços que favorecem a reflexão sobre as diferentes experiências de aprendizagens, de modo que se instale um diálogo com as demandas que surgem. Ao considerar cada uma das crianças como sujeito único, distinto, com histórias pessoais singulares e ao buscar estabelecer maneiras de interligar cada uma delas num coletivo que agrega novas possibilidades de agir, pode-se contribuir para que os processos de subjetivação se constituam de forma integradora. 
Os espaços educativos se tornam potentes facilitadores desses processos ao possibilitarem o contato e imersão das crianças com situações lúdicas que favoreçam e ampliem sua capacidade de brincar; ao promoverem diálogos sobre temas diversos da cultura e também sobre emoções e sentimentos; ao garantirem espaços de trocas e relacionamentos das crianças entre si, estabelecendo também um contato afetivo e respeitoso com adultos que se importam com elas; ao proporcionarem uma rotina que respeite os ritmos $\mathrm{e}$ as necessidades corporais, oferecendo possibilidades de agitação/descanso, sujeira/asseio, ordem/desordem e fome/sede/saciedade.

Mas, para que isso ocorra, é necessário que haja espaço para observação, tematização e reflexão das práticas instauradas. Nas quais se possa pensar (sobre) as crianças e suas famílias, tomando cuidado para não ocorra a fixação em estereótipos ou em supostos diagnósticos. Lembrando-se sempre que o espaço educacional é um espaço de convívio saudável, não clínico, que oferece muitas possibilidades de ser e estar a cada uma das crianças que têm a oportunidade de frequentá-los. 


\section{CAPÍTULO 5. O BRINCAR NO COTIDIANO EDUCATIVO}

Para tratar dessa questão, William Corsaro (2005) será tomado como referência. A escolha do autor se deu por sua proposição em relação ao papel do adulto na observação das crianças tal qual ele apresenta a partir do método etnográfico. Ao colocar-se entre elas como um adulto não típico ${ }^{10}$, fez muitas descobertas sobre as relações que estabelecem entre si. Nesse sentido, merece destaque a partilha, a construção de enredos e a representação de temáticas que as mobilizam e o uso de um vocabulário enriquecido.

No âmbito desta pesquisa, esse modo de pensar e pesquisar o brincar é extremamente proveitoso para a ação educativa com as crianças, pois ao observá-las (de perto) brincando, é possível entrar em contato com sua forma de entender e pensar o mundo adulto, com o quanto se apropriam de conceitos, ao mesmo tempo que os modificam em função de suas possibilidades cognitivas, discursivas e emocionais e com isto podem-se encontrar diferentes maneiras de interagir, agregar elementos às suas brincadeiras e propor-lhes problemas a resolver.

A observação de crianças brincando torna visível suas descobertas, seus interesses e interrogações. Há momentos em que as brincadeiras ocorrem ao acaso, isto é, ao depararem-se com determinado material, iniciam uma exploração aleatória e a partir da resposta recebida, colocam-se objetivos e passam a persegui-los. Um exemplo disto, pode ser visto, quando um bebê descobre que ao bater com um pedaço de madeira em potes, produz sons diferentes e passa a repetir essa ação com todos os objetos que encontra ao seu redor. Ao notar que determinado objeto produz um som mais alto, ele começa a testar o ritmo de suas batidas, como se estivesse se perguntando se sua força interfere no resultado obtido. É comum que ele procure o olhar de um adulto, como forma de confirmar e partilhar sua descoberta.

A partir dessa observação, é possível, num segundo momento, oferecer baquetas e potes para que a criança retome sua exploração dos sons e, com isto, verificar se o interesse se mantém, se suas ações se tornam mais intencionais, se seus atos perseguem um objetivo mais explícito. Aqui destaca-se a contribuição de Dewey (1979, p. 17) ao

\footnotetext{
${ }^{10}$ Corsaro se colocava em áreas usadas apenas pelas crianças para observá-las e aguardava que elas interagissem com ele, sem ter que atuar como um mediador dos eventuais conflitos.
} 
afirmar que cabe "ao educador a seleção das experiências presentes, que devem ser do tipo das que irão influir frutífera e criadoramente nas experiências subsequentes".

A educadora que se mantém atenta às ações das crianças, passa a perceber aquilo que desperta seu interesse e a regularidade de suas ações, tornando-se sensível em relação às intervenções que lhe cabe. Isto é, podendo tanto assegurar o brincar livre (porém, sempre assistido por ela), como a introdução de objetos e desafios que suscitem novas descobertas.

Segundo Laevers (2005), as escalas de bem-estar e envolvimento são ótimos instrumentos para orientar as educadoras em suas observações, uma vez que ao acompanharem individualmente uma criança brincando, podem se inteirar sobre o que desperta seu interesse, sobre a adequação dos espaços e materiais utilizados e como o bem-estar e a segurança da criança interfere em sua implicação na situação de brincadeira.

\begin{abstract}
A organização de um ambiente rico não se completa apenas com a provisão de ampla variedade de materiais e atividades potencialmente interessantes. Um elemento decisivo para a ocorrência de envolvimento é a forma como o adulto apoia as atividades em andamento com intervenções estimulantes. LAEVERS, 2014. p. 162).
\end{abstract}

A seleção de materiais também pode ocorrer de forma intencional por parte das educadoras, como maneira de potencializar as brincadeiras. Elionor Goldschmied e Sonia Jackson (2006) criaram uma abordagem de aprendizagem a qual nomearam de brincar heurístico com objetos que favorece em muito a criação de brincadeiras pelas crianças. A partir da disponibilização de uma diversidade de receptáculos e de materiais não estruturados ${ }^{11}$, as crianças que já se movimentam com certa autonomia realizam uma série de descobertas sobre eles.

As crianças percebem que alguns se encaixam nos outros, mas que objetos semelhantes, porém de menor tamanho não se encaixam; que potes grandes ficam pesados quando preenchidos por pedras, mas mantém-se leves quando preenchidos por bolinhas plásticas; que cones escondem objetos dentro de si e, quando retirados do lugar não carregam os objetos consigo; caixas sem tampas e bacias não escondem os objetos, mas servem para carregá-los de um lugar para o outro.

\footnotetext{
${ }^{11}$ Esses materiais podem ser de diferentes formas e tamanhos, tais como: blocos de madeira, caixas, botões, lãs, pedras, placas de acrílico, tecidos, canos, tampas de garrafas, cordas, plotters, pedras, carretéis de linha, cestos, caixas, bacias, entre tantos outros.
} 
A partir das observações, as educadoras podem notar a regularidade das ações de cada uma das crianças e quais os problemas que se colocam ao manipular esses objetos. Encaixar, tirar, pôr, passar por dentro, lançar, olhar no buraquinho, puxar, jogar, entrar, sair, se esconder, achar, esconder os objetos são algumas das ações frequentes no uso desses materiais.

As crianças maiores, com três anos, ao usarem esses mesmos brinquedos, além de se interessarem por suas propriedades físicas, começam a atribuir-lhes significados simbólicos e criam enredos narrativos para suas brincadeiras, como podemos ver nos registros feitos pelas educadoras do espaço ekoa Samantha Santos e Fabiana Rangel para a documentação do trabalho com suas turmas:

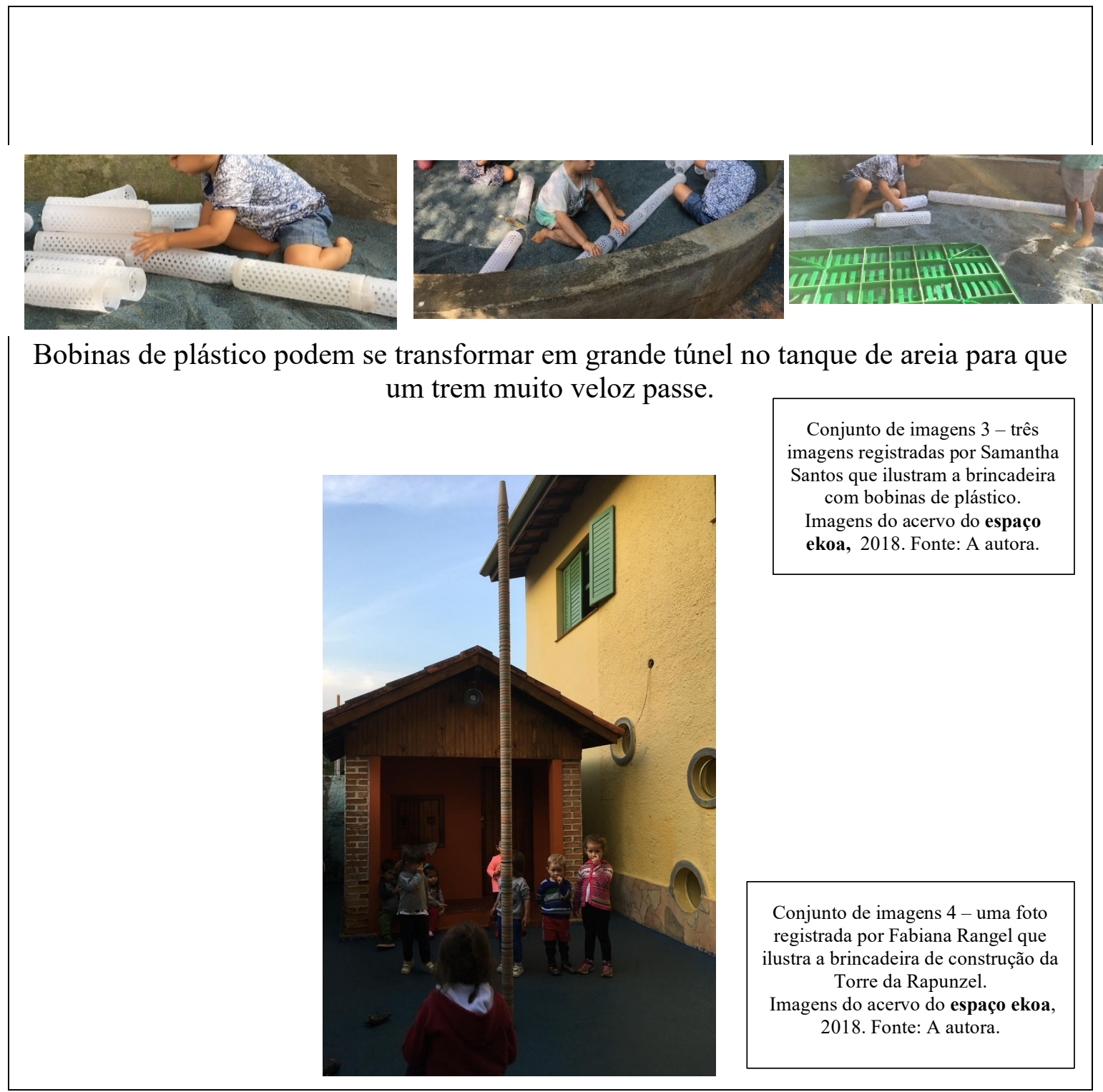

Cones de papelão empilhados formam a torre da Rapunzel 
Esses materiais são considerados brinquedos de largo alcance (LEONTIEV, 1998), pois proporcionam uma gama infinita de possibilidades de exploração, nas quais ora detém-se aos seus atributos físicos, ora atribuem diferentes significados lúdicos para eles. Esses dois exemplos elucidam que as educadoras podem intervir em ações futuras, oferecendo espaços e materiais semelhantes, para garantir a continuidade das brincadeiras e das relações que as crianças estabeleceram entre si, tal como esclarece Dewey $(1979, \mathrm{p}$. 32):

\begin{abstract}
A responsabilidade primária do educador não é apenas a de estar atento ao princípio geral de que as condições do meio modelam a experiência presente do aluno, mas também a de reconhecer nas situações concretas que circunstâncias ambientes conduzem a experiências que levam a crescimento. Acima de tudo, deve saber como utilizar as condições físicas e sociais do ambiente para delas extrair tudo que possa contribuir para um corpo de experiências saudáveis e válidas.
\end{abstract}

Partindo do pressuposto apresentado por Leontiev (1988), a brincadeira deve ser considerada como uma atividade com um fim em si mesma, na qual o que importa é o processo e não seu resultado, por isso, a repetição das situações se faz tão importante, uma vez que intensificam as experiências e processos vivenciados pelas crianças.

\title{
Bolinhas e Cones
}

$\mathrm{Na}$ observação de crianças brincando muitas surpresas aparecem, pois nem sempre o que parece ser o objetivo da brincadeira permanece o mesmo durante todo o processo. Por vezes, as crianças brincam de modo extremamente ordenado, numa Conjunto de imagens 5 - uma imagem
registrada por Samantha Santos que ilustra
a brincadeira com cones de papelão e
bolinhas.
Imagem do acervo do espaço ekoa, 2018.
Fonte: A autora. sequência que induz a um começo, meio e fim, mas ao lidarem com os materiais, novos interesses surgem, mudando o curso das ações, mas ainda mantendo seu caráter lúdico.

Como exemplo, há a brincadeira de duas crianças, em um canto organizado com materiais diversos. Quando uma delas encontrou um balde com bolinhas ao lado de uma mesa com cones de plástico e de papelão e começou a equilibrá-las sobre eles, despertou a atenção de outra criança que logo se uniu à brincadeira. Ambas ficaram 
um bom tempo envolvidas, sem se importarem quando as bolinhas caiam ou eram pegas por algum amigo. Depois de colocarem bolinhas sobre todos os cones, as crianças se olharam e, sem falarem nada, começaram a derrubar tudo o que estava em cima da mesa. Caíram na gargalhada e passaram a organizar os materiais, empilhar as bolinhas, para depois derrubar.

Destaque-se, novamente, a importância de serem realizadas observações das ações das crianças pequenas, tomando como referência as escalas de bem-estar e desenvolvimento (LAEVERS, 2014), pois elas auxiliam na decodificação de suas ações. Ao acompanhar uma mesma criança, por dois minutos seguidos, numa brincadeira e retomar o acompanhamento por pelo menos mais duas vezes, totalizando seis minutos de observação, é possível fazer uma imersão em seu foco de interesse e compreender que ações que parecem desconectadas e aleatórias, na verdade são extremamente intencionais.

Um exemplo disso, foi a observação de um menino de dois anos e cinco meses, que ao brincar com os mesmos materiais descritos acima, recolhia a maior quantidade, levando-os de um canto da sala para o outro. Inicialmente, parecia que ele estava apenas retirando os materiais de circulação, como se não quisesse que ninguém usasse. Durante a observação, porém, foi possível notar que sua brincadeira era a de acumular a maior quantidade de objetos e mesmo com os colegas retirando os objetos, ele não se importava e continuava pegando-os. Essa cena, se repetiu nas outras duas observações feitas em momentos distintos, sendo uma delas no tanque de areia, quando essa mesma criança retirava os brinquedos da caixa plástica e levava-os para dentro de um pneu que fica no centro do tanque. Dessa vez, à medida que colocava os brinquedos no centro do pneu, outra criança os retirava, numa ação coordenada, mas não pactuada entre eles.

\section{O Lobo}

Durante dias seguidos, um grupo que variava entre três e seis crianças se aglutinava num canto do jardim e ficava jogando pedra e terra no piso de cimento em frente. As crianças gritavam, sorriam e jogavam a terra continuamente. Muitos adultos passavam, pediam para que parassem de sujar o chão e mostravam que poderiam jogar a terra dentro do próprio jardim, numa tentativa de conter a bagunça. Por um período pequeno, elas paravam, mas logo voltavam a jogar terra. Dias se passaram e mais e mais crianças se juntavam à brincadeira, então a educadora da turma, Leticia Pereira, decidiu 
se aproximar para entender melhor o que elas estavam fazendo e descobriu que estavam jogando comida para o lobo!

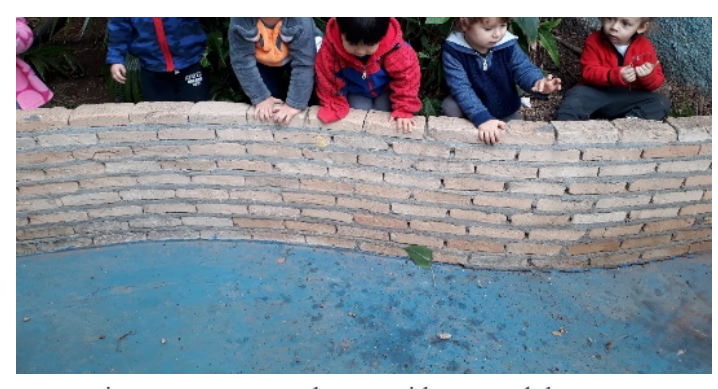

crianças arremessando a comida para o lobo

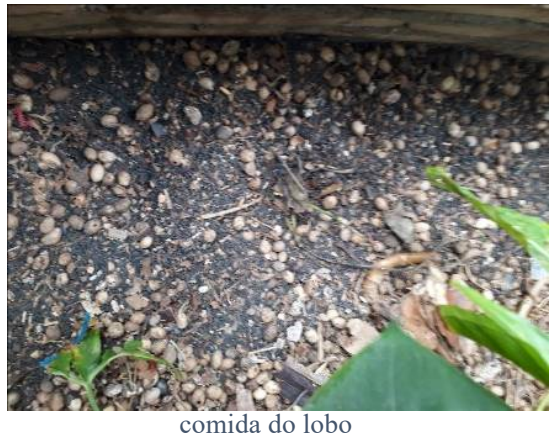

comida do lobo

Conjunto de imagens 6 - duas imagens registradas por Leticia Pereira que ilustram a brincadeira do lobo.

Imagens do acervo do espaço ekoa, e 2018. .

Fonte: A Autora

Analisando essa cena, até o momento em que a educadora resolveu entender qual era a brincadeira, todos os adultos estavam atuando de modo externo, vendo apenas um grupo de crianças, agindo sem um propósito explícito, sujando um pátio. Se, desde o primeiro momento, alguma educadora tivesse se aproximado, como sugere Corsaro (2002), como um adulto não típico, poderia ter ouvido o diálogo das crianças e entendido de pronto o que estavam fazendo.

Isto favorece pensar no quanto toda e qualquer educadora, deve procurar compreender e se inteirar sobre as motivações das crianças, antes de simplesmente tentar corrigi-las e chamar sua atenção frente a algo que lhe parece inadequado.

\section{Brincadeira de Casinha}

É muito frequente ver crianças entre dois anos e meio e três anos brincando de casinha. Às vezes, nota-se que algumas crianças alternam os papéis conforme o momento, criando brincadeiras que giram em torno da representação de pessoas de seu núcleo familiar, por vezes representam uma mãe grávida, depois a mãe cuidando de um bebê pequeno, em outros momentos brincam de ser o pai ou um bebê recém-nascido. Essas vivências costumam ser partilhadas com os colegas que contribuem com novos enredos aos papéis representados: de mãe zelosa, bebê que não dorme, filha que chora, pai que trabalha, entre outros. 
A partir de observações, pôde-se notar que a brincadeira começava com uma criança colocando uma bola na barriga, dizendo que estava grávida e assumindo outro nome, muitas vezes da própria mãe. Gradativamente, outras crianças da turma se aproximavam para participar da brincadeira. Os brinquedos e materiais eram organizados por elas para comporem cenários diversificados. Numa das vezes observadas pela autora da pesquisa, um grupo de crianças usou blocos de madeira (de $20 \times 20 \times 10 \mathrm{~cm}$ ), para "fazer uma casa construída", como uma delas falou, para um bebê poder morar e depois começaram a levar comidinhas (tocos de madeira e brinquedos em forma de comidas) para alimentá-lo.

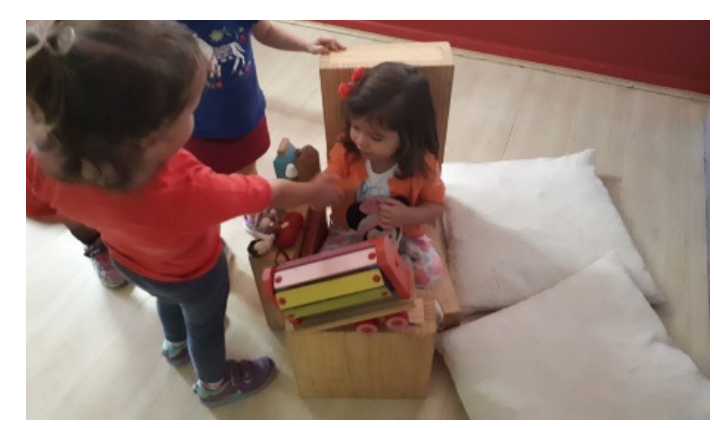

crianças construindo a casa para o bebê.

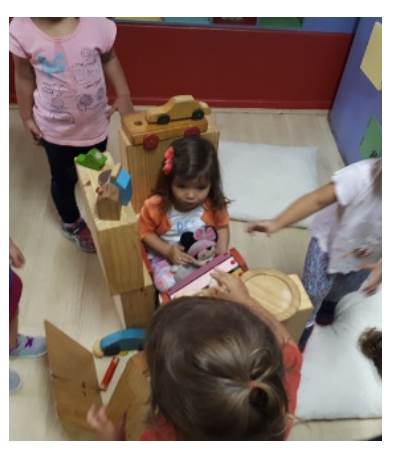

crianças colocando comidinhas e brinquedos para o bebê.

$$
\begin{gathered}
\text { Conjunto de imagens } 7- \\
\text { duas imagens registradas por } \\
\text { Marina Mourão que ilustram } \\
\text { a brincadeira de casinha. } \\
\text { Imagens do acervo do } \\
\text { espaço ekoa, 2018. Fonte: A } \\
\text { Auorira }
\end{gathered}
$$

Num outro dia, foi possível observar duas crianças brincando de mamãe e filhinha e uma delas, que estava representando a mãe, reagiu de modo mais bravo a uma solicitação "de sua filhinha". Com base em observações como essas, pode-se perceber que as crianças se aproveitam, de forma muito especial, das brincadeiras para transitarem pelos diferentes papéis, sendo mamães grávidas, bebês que precisam de cuidados ou uma mamãe atarefada, tal como Bruner (2010, p. 03) nos assinala "[...] jogar com outras crianças tem um papel terapêutico importante, ou, de qualquer forma, um papel importante para preparar as crianças para os enfrentamentos sociais de sua vida adulta". 


\section{Jogo de Futebol}

Um grupo de meninos de três anos jogava bola quando uma menina se aproximou e pediu para jogar com eles, mas foi impedida de brincar. Chorando, ela pediu ajuda para que um adulto fosse conversar com os meninos. De modo cauteloso, eles foram chamados e, ao contar que a colega tinha ficado chateada por não poder jogar, eles, quase que em coro, responderam que "menina não joga futebol!". A fim de interceder, foi falado que ela poderia sim jogar, mas antes que pudessem concluir um dos meninos falou que "no time do São Paulo não tinha meninas" e outro menino completou "na minha televisão, na Copa do Mundo ${ }^{12}$ só tem menino!". Como eles tinham razão em seus argumentos e como a menina se desinteressou pela brincadeira a conversa não teve prosseguimento. Porém, é necessário pensar nas influências da cultura na definição das brincadeiras, tal como Brougère (2000) nos apresenta em seu texto As culturas lúdicas têm sexo. O argumento usado pelos meninos é mesmo incontestável, pois o futebol masculino está sempre em evidência e não há jogos mistos, mas certamente cabem conversas e problematizações que possam fazê-los vislumbrar a possibilidade de jogarem bola, tanto com meninas, como com meninos.

É primordial que os espaços educativos rompam com as barreiras estereotipadas que categorizam as brincadeiras em função do sexo e, progressivamente, consigam diferenciar a busca de cada uma das crianças, de diferentes gêneros, por brinquedos e brincadeiras que despertam sua atenção, sem que isso seja considerado um problema.

Retomando a brincadeira de casinha, já se observou que meninos cujas mães estavam grávidas brincavam de colocar bola em sua barriga, numa representação explícita de gravidez. Há mais tempo, a autora da pesquisa observou um menino, que ao brincar com bonecas, costumava colocá-las sobre seus ombros, numa representação típica da brincadeira de cavalinho que é mais frequente entre pais (homens) e filhos(as).

Assim, ao explorar os universos diversos as crianças poderão se abastecer de formas mais igualitárias para estabelecerem relações, por isso, mais uma vez reafirmamos a necessidade de os espaços educativos proporcionarem múltiplas experiências nesse sentido.

\footnotetext{
${ }^{12}$ Era ano de Copa do Mundo de futebol masculino.
} 


\section{Brincadeiras com Regras Simples}

Ao longo do primeiro semestre de 2018, as turmas de crianças de três anos do espaço ekoa, realizaram um projeto no qual foram apresentadas às brincadeiras tradicionais das quais destacamos apenas duas: amarelinha e alturinha ${ }^{13}$.A cada semana, as crianças iam se familiarizando com os rituais de cada uma das brincadeiras, demonstrando em suas ações as maneiras peculiares como assimilavam suas regras.

$\mathrm{Na}$ brincadeira de amarelinha, a maior parte delas, mantinha a sequência de lançar uma pedrinha ou toco de madeira e percorrer os quadrados, alternando entre colocar os dois pés no chão ou apenas um. Como em termos motores ainda não davam conta de saltar, faziam ajustes corporais muito interessantes, algumas corriam e tiravam um pé do chão, quando tinha apenas um quadrado; outras faziam um galope e tentavam se equilibrar em um pé só; outras corriam pelos quadrados; outras saltavam abrindo as pernas quando tinham dois quadrados e fechando, quando era só um.
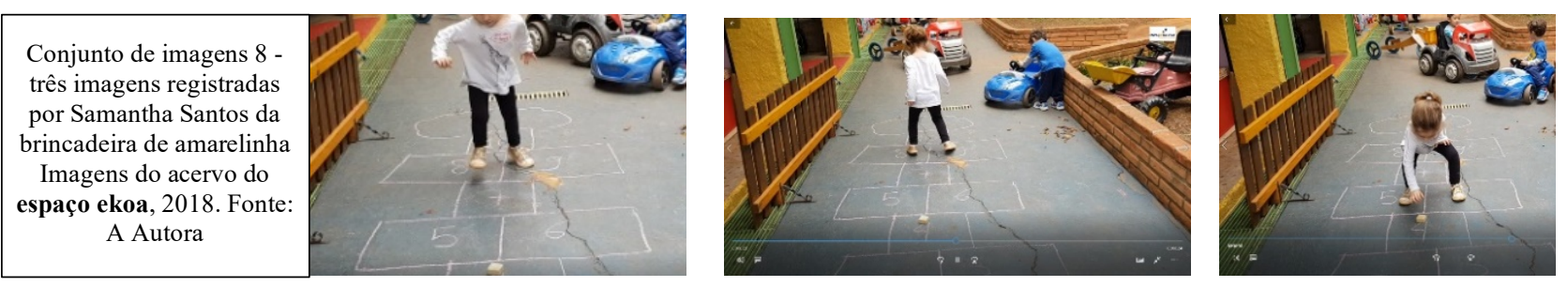

$\mathrm{Na}$ brincadeira de alturinha, a participação de todas as crianças era sempre muito intensa e as adaptações também ocorriam para que pudessem dar conta de suas ações ou mesmo de seus desejos. Para algumas crianças, era difícil subir em algum plano elevado, então permaneciam no chão ou aguardavam o auxílio da educadora. Existiam crianças que, mesmo durante a cantoria, se mantinham no obstáculo escolhido para não se tornarem nunca galinha choca. Por outro lado, existiam crianças que nem procuravam um local para subir, pois queriam ser a galinha choca.

${ }^{13}$ Essa é uma brincadeira na qual se canta uma música ou recita-se uma parlenda e quem estiver comandando fala "alturinha" e todos os participantes têm que subir em um local alto. Se por acaso alguém não subir, vira "galinha choca" e todos cantam em coro "Galinha choca, comeu minhoca, ficou pulando feito pipoca", em seguida, a brincadeira recomeça. 

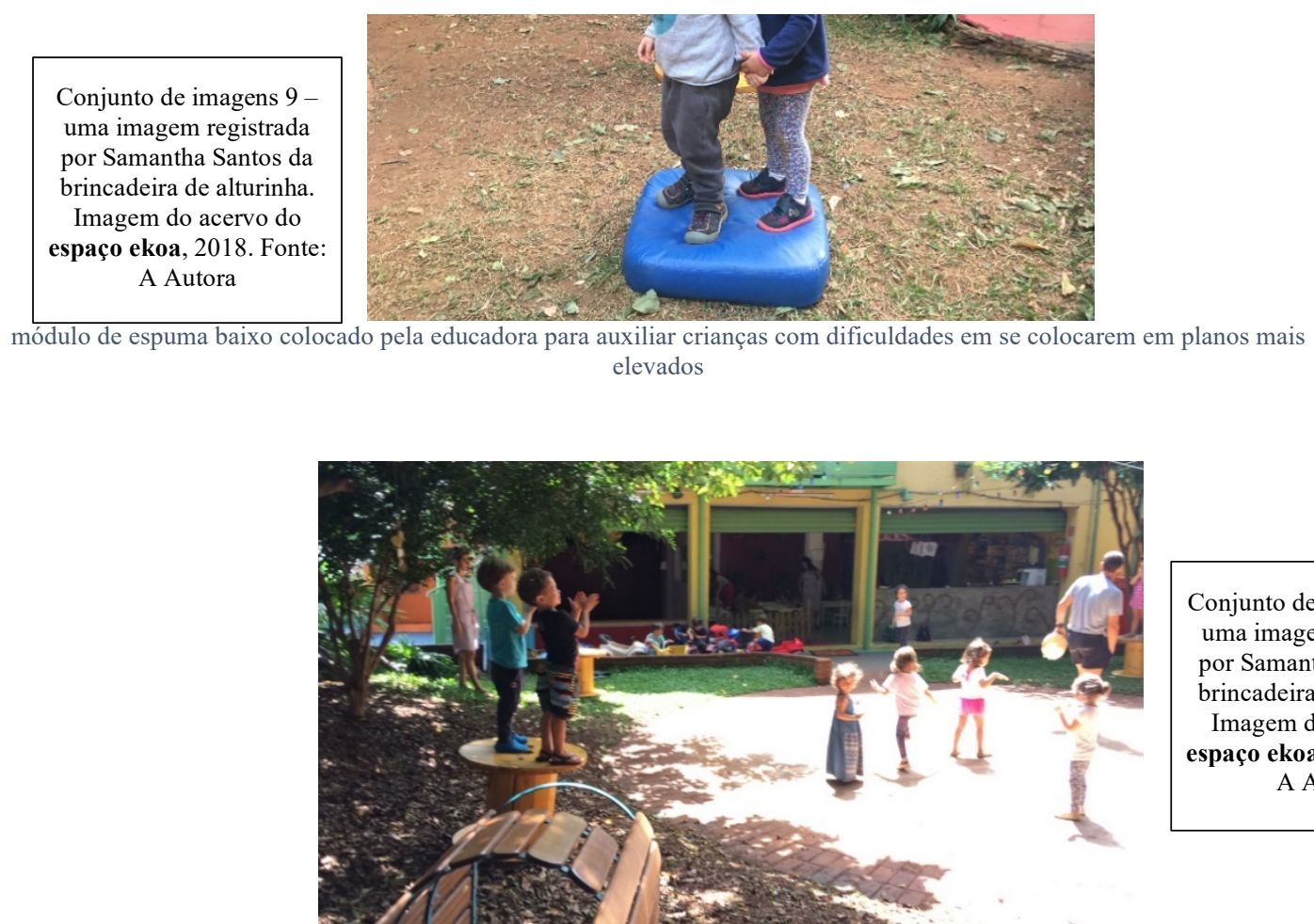

Conjunto de imagens $10-$ uma imagem registrada por Samantha Santos da brincadeira de alturinha. Imagem do acervo do espaço ekoa, 2018. Fonte: A Autora

Crianças que se mantiveram "nas alturas" para não virarem galinhas chocas

Em todos os momentos de brincadeira dirigida, os educadores ${ }^{14}$ se mantinham presentes, conversavam e retomavam as regras, mas não intervinham com ações corretivas, pois isto poderia tirar o caráter lúdico das propostas, uma vez que não faz sentido exigir que crianças dessa faixa etária realizem gestos específicos e coordenados e sigam estritamente às regras das brincadeiras, além de suas possibilidades físicas e cognitivas de momento.

Para que as brincadeiras fluíssem, os educadores intencionalmente deixavam que as crianças pautassem suas escolhas em função de seus desejos. Dando-lhes espaço para a experimentação de ações e gestos que não fariam se não tivessem sido convidadas a participar de tais jogos.

\section{Interligando os Relatos}

Não bastam espaços, materiais e repertórios adequados, há a necessidade da presença de adultos sensíveis, atentos para transformar o ambiente institucional em um local onde predomina a ludicidade. É necessário que o profissional que atua diretamente com a criança bem pequena tenha conhecimento sobre a "cultura lúdica" (BARBOSA, 2009, p. 73).

\footnotetext{
${ }^{14}$ Educadores no masculino, pois o professor de Corpo em Movimento participou de algumas das propostas,
} 
Os referenciais teóricos auxiliam a educadora a promover o brincar e facilitar a criação de brincadeiras individuais e brincadeiras partilhadas entre duas ou mais crianças. Para tanto, considera-se importante que a educadora se coloque à disposição e atenta às necessidades de seu grupo, auxiliando na seleção dos materiais, escolha dos espaços, mediando a partilha dos objetos e intervindo em situações de conflitos.

A observação, escuta e registro formam uma tríade necessária para garantir a visibilidade das ações e maior assertividade nas intervenções das educadoras, uma vez que passam a reconhecer quais experiências mobilizam mais suas crianças.

Portanto, a investigação da multiplicidade e da complexidade do brincar deve ser colocada como ponto central em todo e qualquer projeto pedagógico voltado à primeira infância, com rotinas que garantam momentos para o brincar livre, mediado e dirigido. Cabendo à educadora oferecer, sugerir, intermediar, observar, registrar e, sobretudo, se sensibilizar às respostas e descobertas das crianças pequenas, sempre tão reveladoras de sentidos e significados. 


\section{CAPÍTULO 6. O PAPEL DAS EXPERIÊNCIAS NA EDUCAÇÃO DOS BEBÊS E DAS CRIANÇAS PEQUENAS}

Como já discutido, o objeto desta pesquisa destinou-se a realizar uma reflexão a respeito da necessidade de ampliação do olhar sobre as potencialidades das crianças de primeira infância e os modos como elas se relacionam com o mundo que as rodeia e, com isso, ressignificar as ações organizadas no cotidiano das instituições educativas voltadas a essa faixa etária.

Infelizmente, há um discurso corrente na Educação Infantil que considera os bebês e as crianças pequenas seres frágeis, tomando como ponto de partida aquilo que lhes falta: linguagem, consciência corporal, noções numéricas, representação gráfica e acreditam que devam suprir essa falta a partir de estímulos e cuidados, a fim de que se tornem sujeitos integrados, inteligentes e capazes de aprender (no sentido de apreender) e compreender conteúdos que favoreçam sua participação na vida em sociedade. Essa visão de educação, pressupõe uma educadora que saiba exatamente o que precisa ensinar, pois basta-lhe seguir determinados passos para que tenha êxito nessa tarefa. Compreende os conteúdos por sua progressão, partindo do mais simples ao mais complexo, mas esquece de considerar a criança, o que ela sabe, o que a interessa e como se relaciona com tudo que a cerca.

Em contrapartida, como vimos até aqui, há muitos autores e referenciais teóricos que buscam compreender quem são os bebês e as crianças pequenas e a partir daí, possibilitam a criação de contextos que favoreçam aprendizagens, experiências, convívio, partilhas e inúmeros desafios a eles. Sob esse ponto de vista, não há objetivos prédeterminados a serem alcançados na Educação Infantil, mas a abertura para múltiplas possibilidades de aprendizagens, algumas que serão visíveis e outras que escaparão ao controle de qualquer observador, pois são marcadas por ações sutis e muitas vezes fugazes das crianças.

As crianças podem ser tomadas pelas concepções que as consideram sujeitos ativos, que possuem formas peculiares de se relacionar com pessoas, objetos, materiais e espaços e têm o direito de serem inseridas em contextos significativos que contribuam para a ampliação de suas formas de ser e interagir no mundo.

Larossa (2002, p. 20) propõe que a educação seja pensada "a partir do par experiência/sentido" e a partir daí, passa a explorar o significado mais adequado dessa dupla de palavras para o contexto da educação. Logo de início, ele refuta as ideias 
correntes que vinculam experiência à quantidade de informação, opinião, estimulação e trabalho, isto é, como algo a ser acumulado. Segundo o autor, a experiência deve ser considerada numa dimensão de tempo diferente, que inicia antes dela se efetivar, que é sentida durante seu acontecimento e que deixa marcas após acontecer e, isto só é possível quando os sujeitos (nós) se abrem e se disponibilizam a vivenciá-las. Nesse sentido, a experiência é tomada sob a "possibilidade de algo que nos aconteça". (LAROSSA, 2002, p.24).

Dewey (1979), no livro Experiência e Educação, discute o conceito de experiência a partir de seu caráter e sua funcionalidade. Defende a ideia de que as experiências possuem qualidades, com efeitos imediatos e posteriores. Os efeitos imediatos relacionam-se com o grau de satisfação que oferecem aos indivíduos, sendo então agradáveis ou desagradáveis. Os efeitos mediatos referem-se às influências sobre experiências posteriores, as quais agregam valor educativo a elas.

$\mathrm{O}$ autor defende a perspectiva de que as experiências demandam uma relação com a filosofia da educação e com a continuidade, sendo condizentes com o modelo democrático, favorecendo assim maior número de pessoas. Coloca a importância de o educador ${ }^{15}$ manter-se em interação com suas crianças, oferecendo-lhes possibilidades de continuidade de suas experiências, tanto por garantir condições objetivas para que elas ocorram, como por considerar a relevância de suas condições internas.

Se essas ideias forem tomadas como referências na observação das crianças nos diversos contextos que elas circulam (suas casas, creches, parques, praias, shoppings etc.), vê-se inúmeras situações em que elas se disponibilizam a vivenciar experiências, independentemente do que se espera delas. A todo momento, é possível notar que estão imersas em alguma atividade, procurando entender aquilo que chama sua atenção; seja na observação de uma formiga que transita pelo chão, enquanto uma educadora conta uma história; seja nas feições e sonoridades que a educadora faz e emite nessa mesma situação. Ou, mesmo, em perceber como melhor acomoda seu corpo, quando está próximo do corpo de outras crianças.

Os sons, os gestos, as cores, as texturas, as profundidades dos espaços, as diferentes movimentações, enfim, tudo que ocorre em espaços de vida e convívio, despertam a atenção das crianças e as mobilizam em suas ações, ora de formas mais

\footnotetext{
${ }^{15}$ Nesse caso, pela época em que seu texto foi escrito a referência aos educadores está no masculino.
} 
contemplativas, ora mais ativas, por isso é tão necessário que a educação na primeira infância seja pensada e organizada de modo aberto e não circunscrita a conceitos e aprendizagens considerados válidos apenas pela lógica dos adultos. Para que isso ocorra, é importante que os adultos que se propõem a cuidar e educar de crianças, busquem maneiras de compreender como elas pensam, agem e se relacionam, ao mesmo tempo em que devem saber que muitas coisas lhes escaparão, pois não será possível decodificá-las completamente.

Nisso reside a importância de considerar a criança como um outro, como propõe Larossa (2003, p. 185), como alguém que nos escapa, mas que tentamos entender, escutar e nos relacionar, mesmo que de modo transitório. Vale lembrar, como bem assinala esse autor, que "aí está a vertigem: como a alteridade da infância nos leva a uma região em que não comandam as medidas do nosso saber e do nosso poder". Ou talvez considerálas como estrangeiras, com culturas, percepções e linguagens próprias, das quais os adultos conseguem se aproximar, estabelecer trocas, mas com certas dificuldades.

Como descrevem Corso e Corso (2006, p. 230):

\begin{abstract}
Abandonar a infância implica uma perda de identidade. É como se tivéssemos emigrado e, para habitar uma nova terra, tivéssemos de aceitar esquecer tudo sobre língua, costumes, cheiros e sabores de nossa terra natal. Acessar a idade adulta cobra o preço da amnesia da infância. Esquecemos como procedíamos em relação às fantasias, do modo infantil de compreender o mundo, da língua que falávamos, como se tudo isso nunca tivesse sido nosso. Alguns adultos, podem aprender a falar com as crianças, quando são pais, avós, professores, psicólogos e outros que se ocupam delas, mas funcionarão como bons falantes de uma língua estrangeira,

de que no encontro com as crianças, os adultos sempre terão que lidar com a nunca como nativos dela que um dia foram.
\end{abstract}

A autora acredita que é necessário partir do pressuposto incompletude de entendimentos e a falta de vocabulário sensorial para compreender o que as crianças falam a partir de seus gestos, sons, choros, ações e recusas. Acredita, porém, que partir da observação das crianças, é possível às educadoras aproximação ao que as interessa e mobiliza e, com isso, oferecer espaços, materiais e situações que vão ao encontro de suas ideias.

A artista plástica Anna Marie Holm contava que em seus cursos e na ação com crianças o que a interessava era levar ideias, não para que fossem seguidas, mas porque as crianças sempre acabavam criando possibilidades que ela não tinha sequer imaginado. Ao tomar emprestado esse princípio como norteador do trabalho pedagógico com as crianças pequenas, somando-se a disponibilidade de observação de suas ações, se tornam 
visíveis formas elaboradas e surpreendentes sobre como elas lidam com o que o ambiente e as interações que lhes apresentam. Nesse sentido, faz-se necessária a redefinição do papel das educadoras de primeira infância. Elas devem ser observadoras interessadas em descobrir aquilo que ainda não sabem sobre as crianças. Devem colocar perguntas sobre o que observam e, a partir daí, possam planejar e garantir que o cotidiano educativo seja instigante para todos que o frequentam: crianças, educadoras, funcionários e famílias.

Novamente, destaca-se que a pesquisa etnográfica, tal qual Corsaro (2005), pode favorecer na construção de um modo diferenciado de estudar e observar as ações das crianças. A observação de crianças torna visível suas descobertas, seus interesses e interrogações. Há momentos em que as ações ocorrem ao acaso, isto é, ao depararem-se com determinado material, iniciam uma exploração aleatória e a partir da resposta recebida, colocam-se objetivos e passam a persegui-los. Talvez, possa aqui, tomar emprestado o conceito de deriva, oriundo da Psicogeografia ${ }^{16}$, criado pelo movimento da Internacional Situacionista ${ }^{17}$ em meados do século passado.

\begin{abstract}
A deriva se apresenta como uma técnica de passagem rápida por ambiências variadas. $\mathrm{O}$ conceito de deriva está indissoluvelmente ligado ao reconhecimento de efeitos de natureza psicogeográfica e a afirmação de um comportamento lúdico-construtivo, [...]. a deriva, em seu caráter unitário, compreende o deixar levar-se em sua contradição necessária: o domínio das variáveis psicogeográficas pelo conhecimento e o cálculo de suas possibilidades. (DEBORD, 2003, p.87).
\end{abstract}

A partir da observação de crianças, nota-se que quando lhes é permitido percorrer o ambiente em liberdade, andam numa espécie de errância, sem um destino prédeterminado, sendo conduzidas pelas situações, obstáculos, materiais e relacionamentos que se apresentam, podendo deterem-se ou não a depender de suas motivações internas. Seu andar vira um passeio lúdico e construtivo, a criança deixa-se levar, aceitando as solicitações do terreno e observando sua relação com o espaço, descobrindo novidades e atendando-se a certas regularidades.

A dupla novidade/regularidade parece guiar suas ações, como algo complementar e inerente ao processo de conhecer o mundo que a cerca. Com isso, a educadora que se

\footnotetext{
16 “[...] estudo dos efeitos precisos do meio geográfico, planejado conscientemente ou não, que agem diretamente no comportamento afetivo dos indivíduos". (JACQUES, 2003, p. 65)

${ }^{17}$ Movimento que defendia "uma forma bem particular de errância, uma espécie de flânerie ativa, que vai além da contemplação e que tem como objetivo transformar e recriar o cotidiano de forma mais participativa e lúdica". (BALBI e FERRARA, 2018, p.18).
} 
mantém atenta às suas ações, passa a perceber aquilo que desperta seu interesse, tornandose sensível em relação às intervenções que lhes cabe.

Quando as crianças podem percorrer diferentes caminhos dentro dos espaços educativos, assim como nas derivas, é possível notar uma riqueza de percursos e rotas que são pouco utilizados no cotidiano, quando são conduzidas pelas educadoras. Locais que os corpos adultos não cabem, ou que demandam formas menos usuais de deslocamento, podem ser extremamente acolhedores para elas. Os obstáculos podem se transformar em convites à transposição e os corpos das crianças, que ainda não perderam o contato com chão, não se privam de rastejar, engatinhar, saltar, pendurar ou se acomodar para garantir seu deslocamento.

Talvez um cuidado necessário à educadora seja não se perder em meio à contemplação das descobertas das crianças e sim, transformar o encantamento que perpassa toda observação, na criação de bons entornos, que favoreçam suas ações, interações e relações.

Ao perceberem que estão num espaço seguro, com pessoas que cuidam, se interessam por elas e confiam em suas possibilidades, as crianças vivenciam muitas experiências significativas, pois as experiências são sempre únicas, sentidas de modos distintos por cada sujeito. (LAROSSA, 2002).

\section{As Experiências das Crianças em Oficinas}

Eu acredito em "vida numa oficina de arte". Tem a ver com alguns valores éticos: aprender, de uma maneira harmoniosa, a estar junto num mesmo ambiente, cada um com sua necessidade pessoal; abrir espaço para o outro, sentir respeito pelo trabalho de cada um; respeitar as diferentes formas de expressão. (HOLM, 2004, p.94). 
Mesmo organizando uma rotina bastante flexível, que integra a movimentação das crianças e garante muitos momentos de brincadeiras livres, no espaço ekoa faltavam propostas mais abertas, nas quais elas pudessem decidir se queriam participar ou não e por quanto tempo, sem que fossem reguladas pelos convites dos adultos.

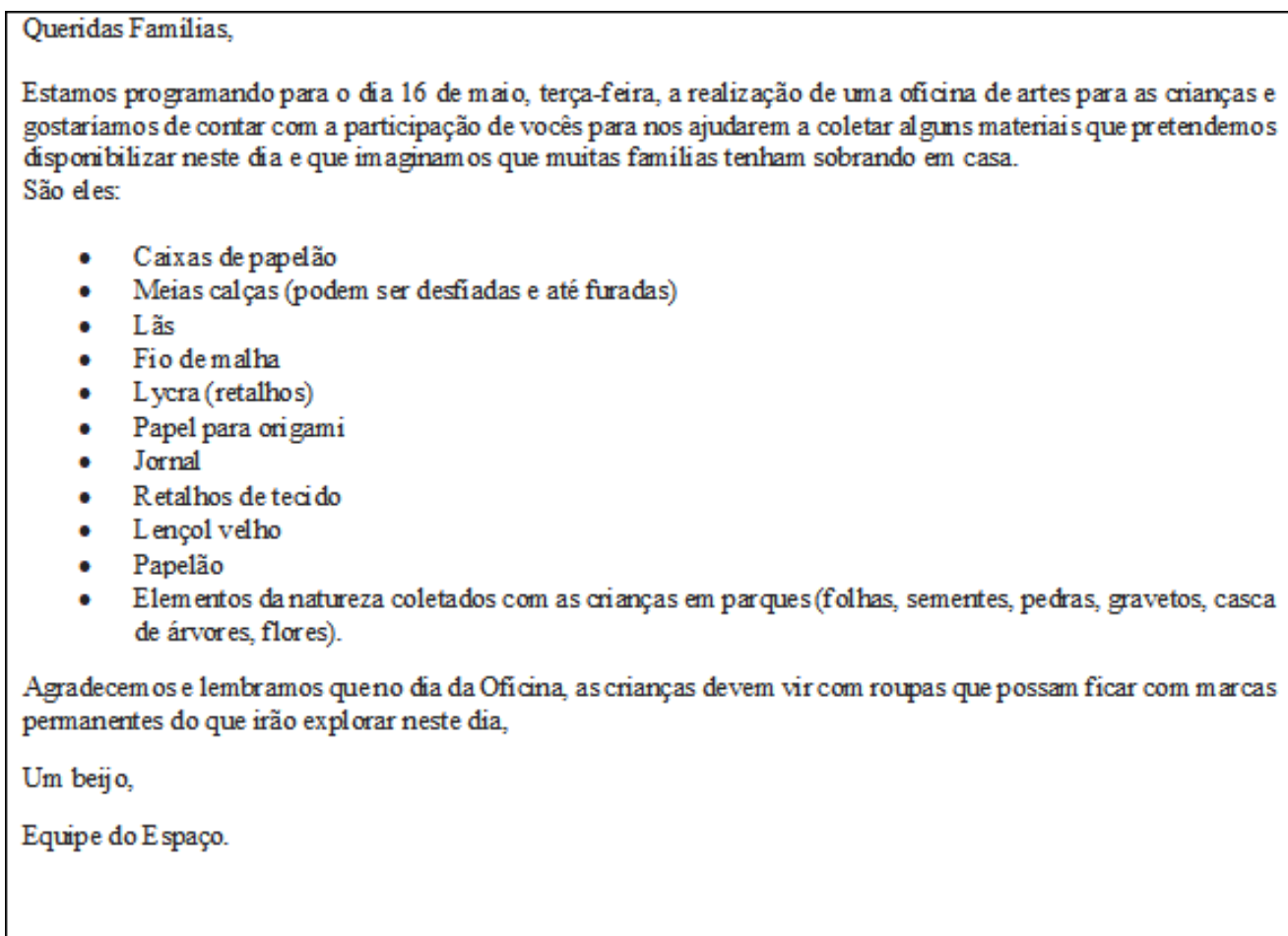

Inspiradas pela leitura do livro Baby-Art, de Anna Marie Holm, a partir de 2008, passaram a ser realizadas grandes oficinas de artes, nas quais o objetivo era favorecer a livre exploração das crianças, sem que elas estivessem organizadas por suas turmas usuais, sem terem que seguir nenhum tipo de comando por parte dos adultos em relação ao uso dos materiais. A ideia era que se sentissem convidadas a explorar as interferências que encontrassem nos diferentes espaços, mesclando a produção artística à brincadeira $\mathrm{e}$ vice-versa. Às vésperas das oficinas, alguns materiais são solicitados às famílias e toda equipe pedagógica se reúne para preparar os diferentes ambientes de forma especial, usando tintas, massinhas, elementos da natureza (pedras, folhas, terras, sementes), linhas e lãs, além de materiais não estruturados (tocos de madeira, cones, tampinhas, tecidos, correntes), dentre outros. 

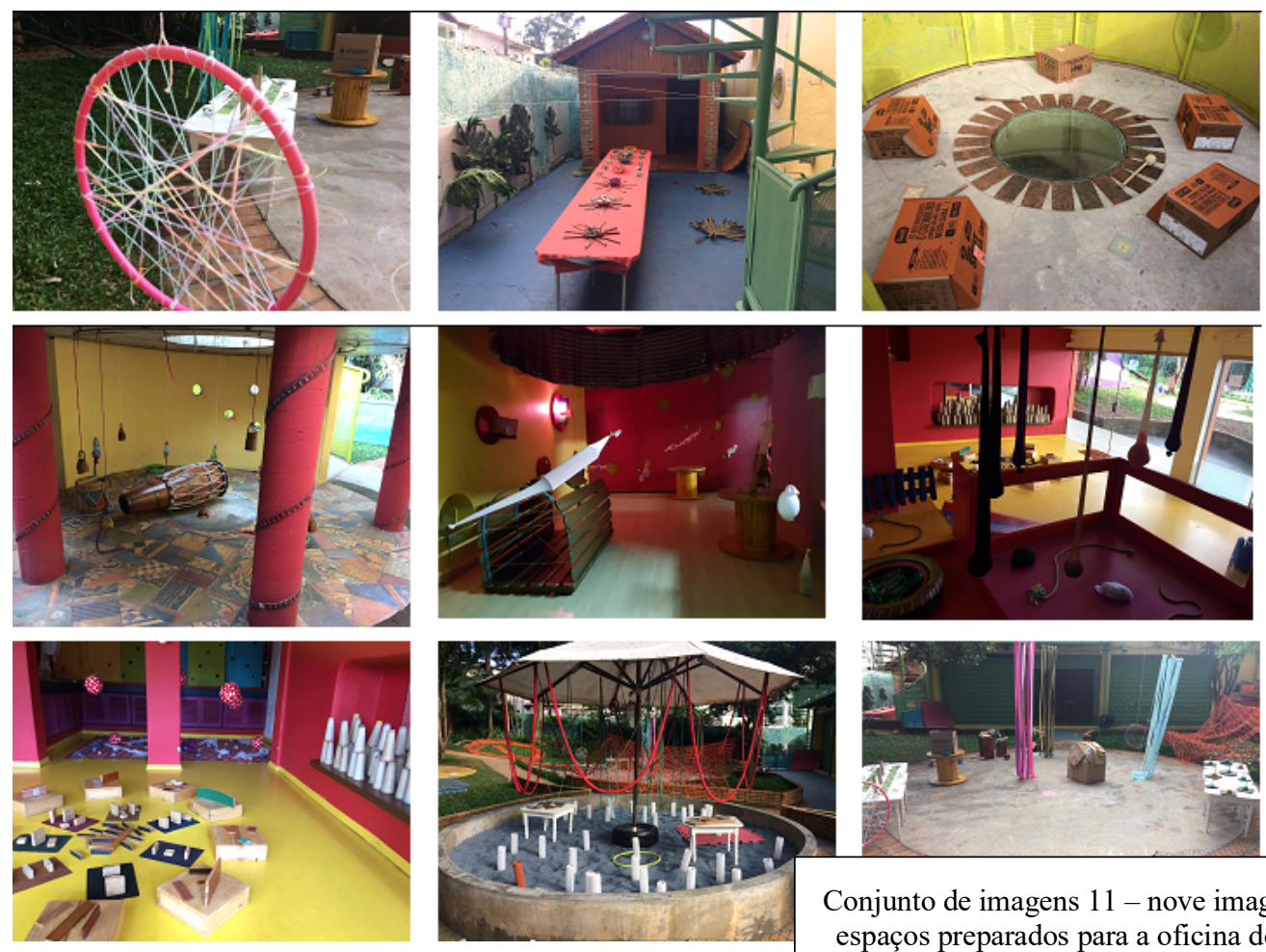

Conjunto de imagens 11 - nove imagens dos espaços preparados para a oficina de 16 de

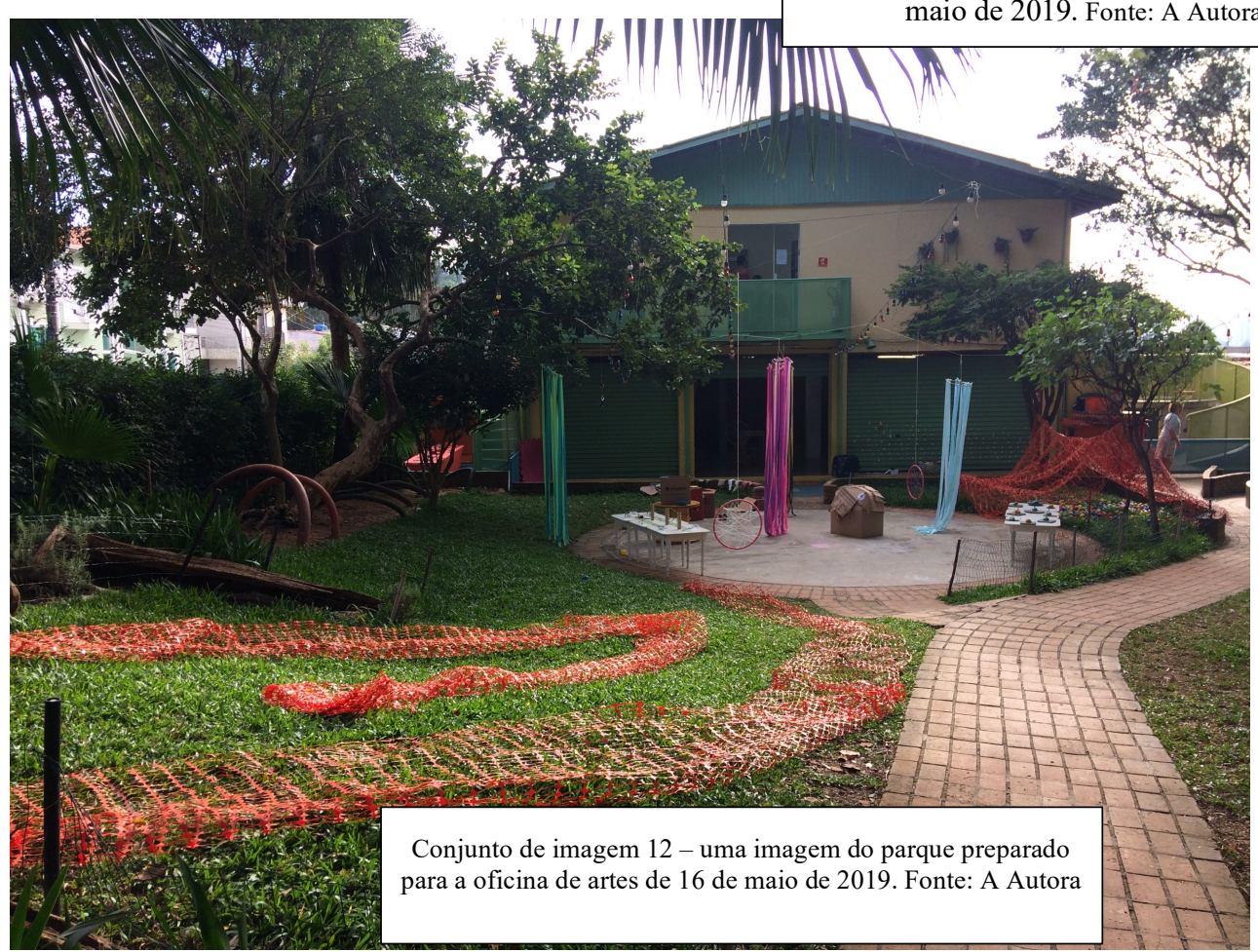

Nesse dia, as crianças são recebidas conjuntamente e, logo, passam a ocupar o parque e demais espaços, realizando suas descobertas. Transitam de um lugar para o outro, sem que haja qualquer tipo de restrição às suas movimentações. De modo geral, o som do ambiente é de muita tranquilidade. Os barulhos são principalmente dos movimentos e das explorações dos materiais; ou decorrentes das brincadeiras e do interesse pelo que cada uma faz, mas há muito silêncio. Um silêncio produtivo, de 
crianças focadas e preenchidas pelas inúmeras possibilidades que se deparam e, talvez, decorrente de características dessa faixa etária, do pensamento sensório motor, no qual as crianças estão realizando experimentações e se conectando com as diferentes possibilidades dos materiais, e ainda não estão voltadas para a criação de enredos, partilhas de descobertas ou convites para brincadeiras, como seria esperado com crianças maiores.

Algumas crianças se movimentam muito durante as oficinas, sobem, descem, num momento estão num espaço, no minuto seguinte estão em outro. Por vezes, partilham da mesma ação com outras, mas logo voltam a ficar sozinhas, fazendo suas descobertas. Outras permanecem praticamente todo tempo no mesmo lugar, explorando os mesmos materiais e contemplando a movimentação das demais. Elas mostram ritmos e formas diferentes de interação e exploração. Mostrando que expansão e contenção, movimento e pausa, barulho e silêncio são ações possíveis e complementares para compreender o entorno e as possibilidades que se apresentam.

Praticamente não ocorrem choros, nem disputas por materiais. Quando duas crianças se interessam pela mesma coisa, sozinhas, elas costumam chegar a um acordo: às vezes, uma espera o abandono do material que deseja pela outra; ou ainda, uma puxa da mão e consegue que a outra se desloque, em busca de outro interesse, sem que nenhuma se sinta prejudicada com a situação.

Em uma dessas oficinas, foi feita uma poça de lama e as educadoras esperaram para ver o que iria acontecer. Foi um episódio rico que foi sintetizado pela autora da pesquisa nesta breve narrativa imagética: 


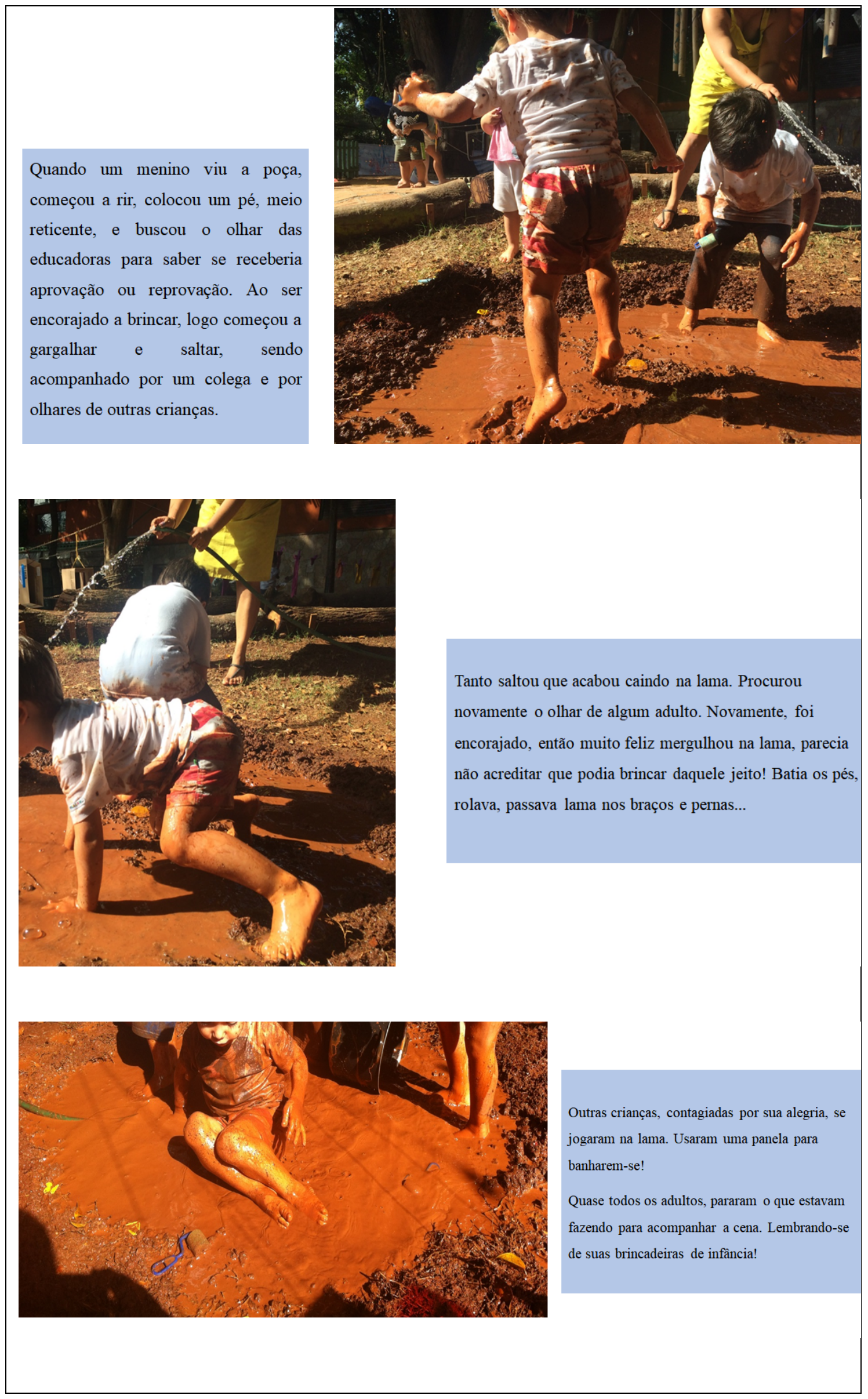




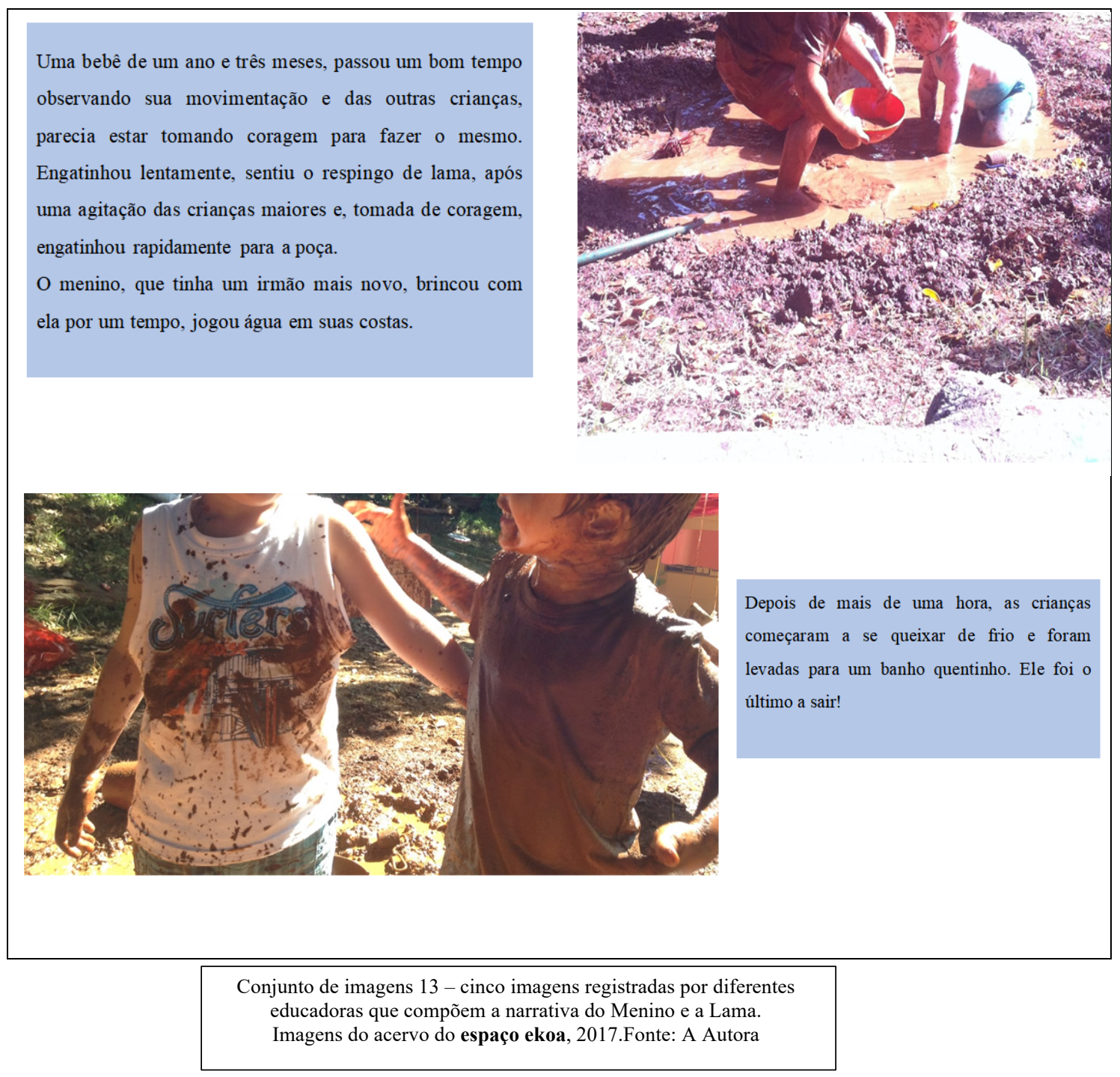

Nessa mesma oficina, algumas crianças ficaram extremamente incomodadas com a lama e tão logo se sujaram, manifestaram desconforto e foram levadas para tomar banho; outras não se interessaram e escolheram os espaços com materiais secos, tais como, canetinhas e giz de cera ou materiais não estruturados (tais como, tocos de madeira, cones, lãs, tecidos, barbantes, gravetos, elementos da natureza, entre outros).

A experiência com a lama ocorreu outras vezes e novamente as reações foram semelhantes. Como o pêndulo prazer e desprazer era intenso, foi decidido deixar esse tipo de exploração para outras oportunidades. Afinal, no instante que a criança se mostra desconfortável, ela precisa ser acolhida por um adulto, pois ainda não consegue limparse da lama, se aquecer e retomar a sensação de bem-estar e não é desejável que em situações como essas que dependam tanto dos adultos. O objetivo é que se vejam com potencialidades e, nesse sentido, buscam-se materiais que sejam facilitadores de suas ações, que ofereçam boas respostas, favoreçam pesquisas, diferentes possibilidades de 
exploração e que as crianças possam ter certo controle sobre eles.

$\mathrm{Na}$ exploração com tintas, mesmo que se sujem intensamente, a sensação de incômodo é menos frequente. As tintas oferecem possibilidades de pesquisas de tonalidades, de densidades e de intensidade na impressão de suas marcas. Podem ser manipuladas com instrumentos (tais como, pincéis, escovas, gravetos, entre outros) ou podem ser manipuladas com os dedos, as mãos, os pés ou com o corpo inteiro.

As formas de explorá-las também variam. Há crianças que praticamente mergulham nos potes de tinta, misturam todas as cores e imprimem marcas em muitos lugares, enquanto outras se aproximam lentamente, como numa pausa, na qual pouco a pouco vão testando e fazendo descobertas sobre o que podem fazer com elas.

Segue abaixo uma mini-história produzida pela autora da pesquisa, a partir dos registros fotográficos da educadora Leticia Pereira.

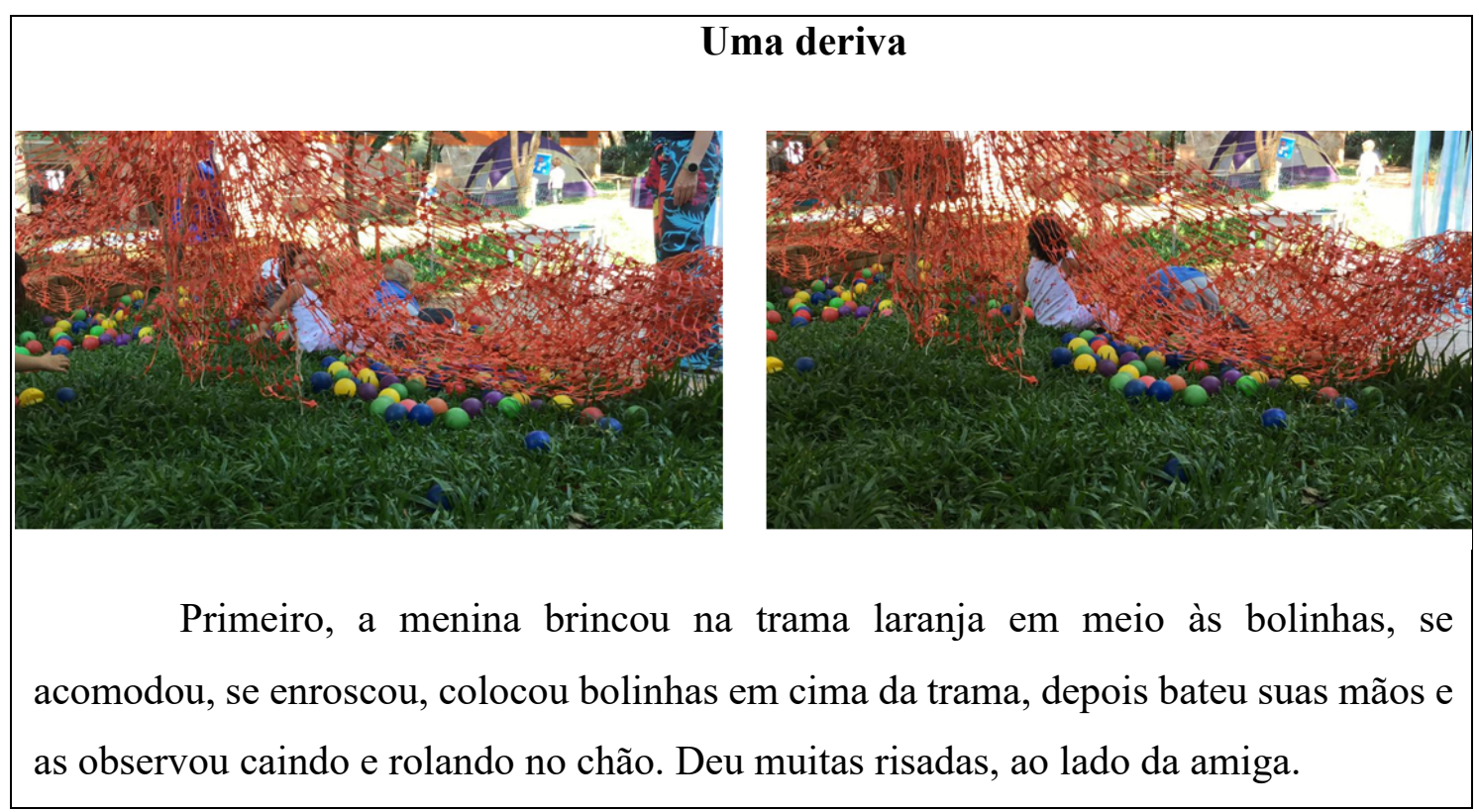




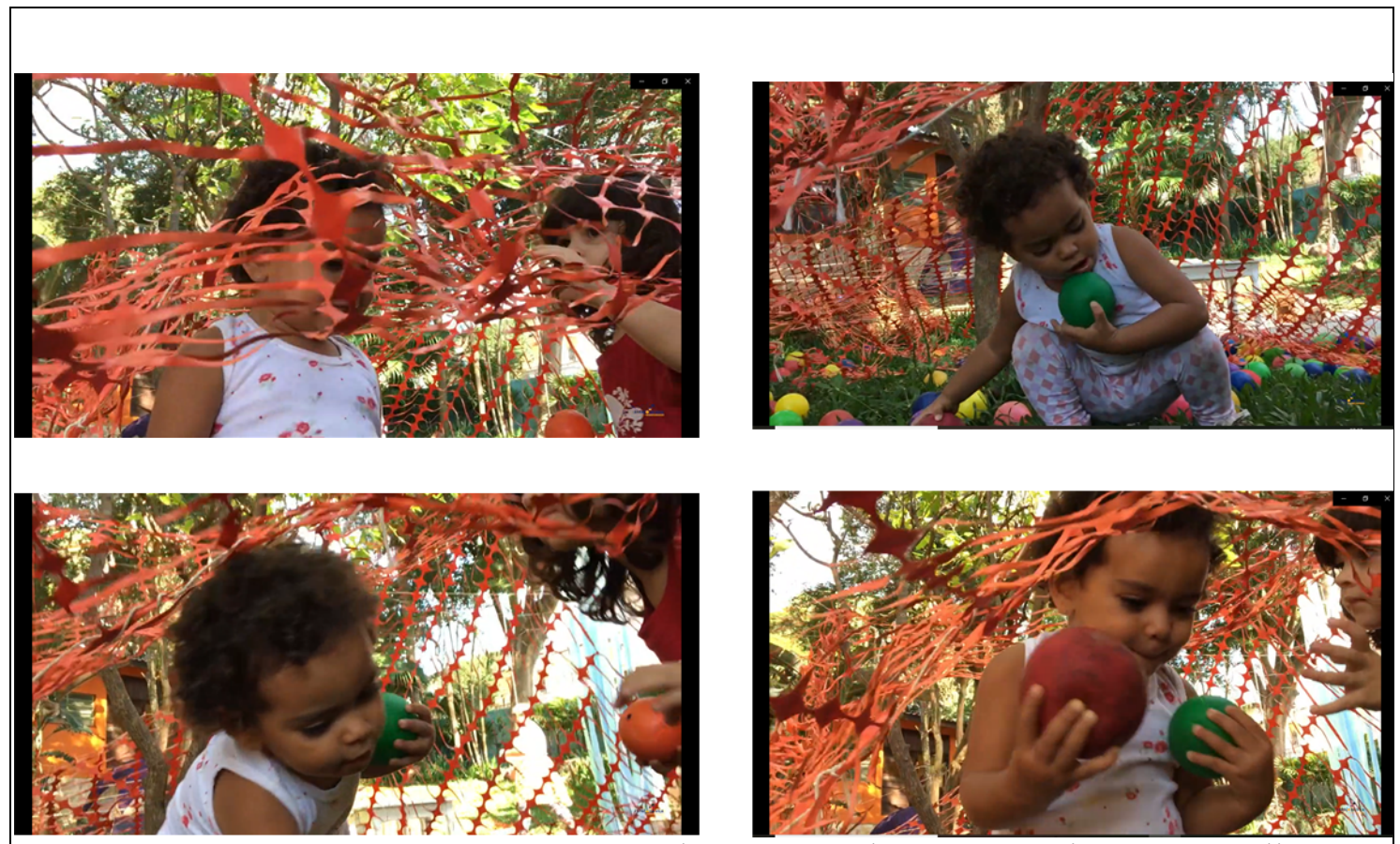

Percorreu outros espaços, sem se deter em nenhum, por muito tempo. Olhava o que as outras crianças faziam, andava mais um pouco, subia e descia a rampa do parque, até que se deitou no chão amarelo, ficando próxima a um prato com tintas deixado por outra criança.

Colocou a ponta de um dedo na tinta, depois começou a deslizar o dedo pelo prato. Ficou de barriga para cima e começou a tingir outro dedo, com o dedo que já estava colorido. Achou isto tão interessante de observar que resolveu sentar e tingir toda mão.
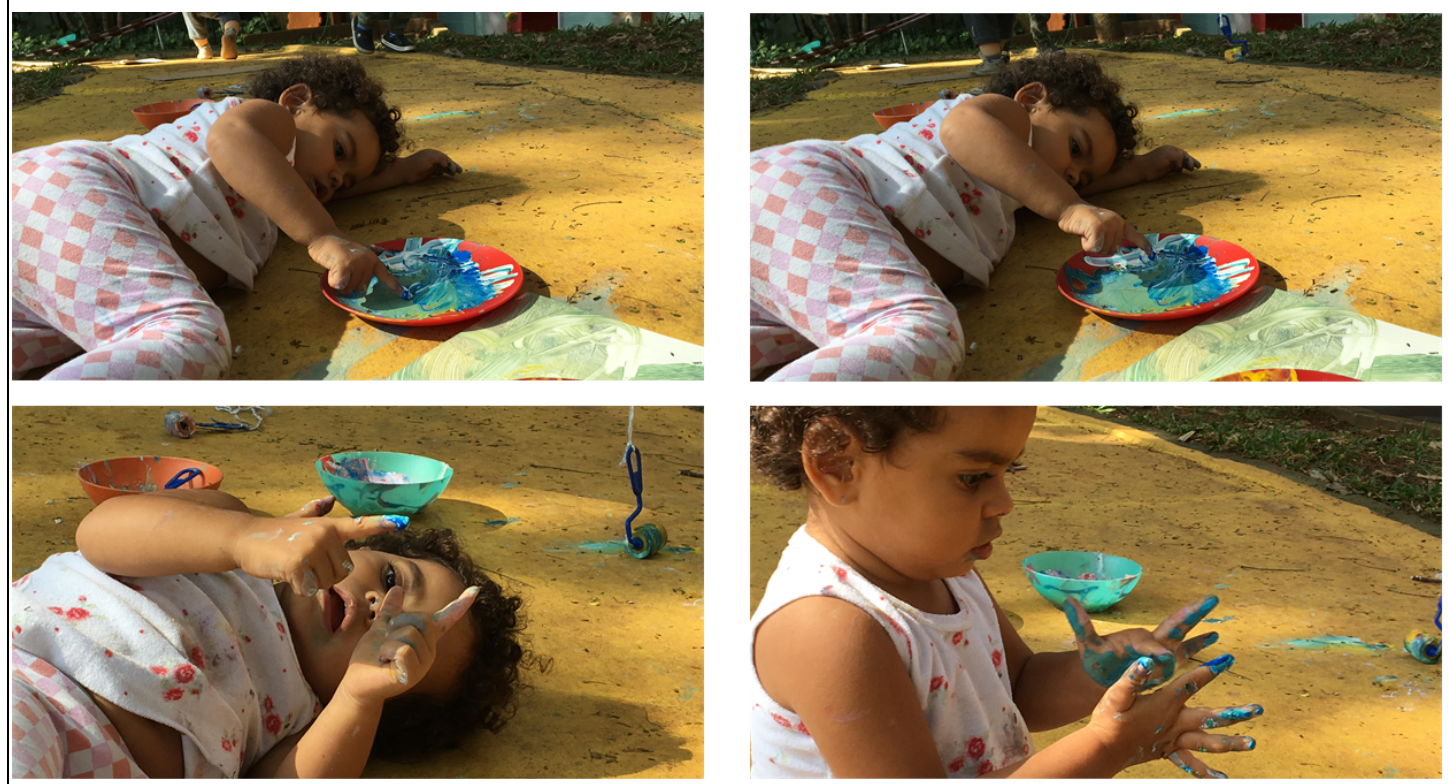


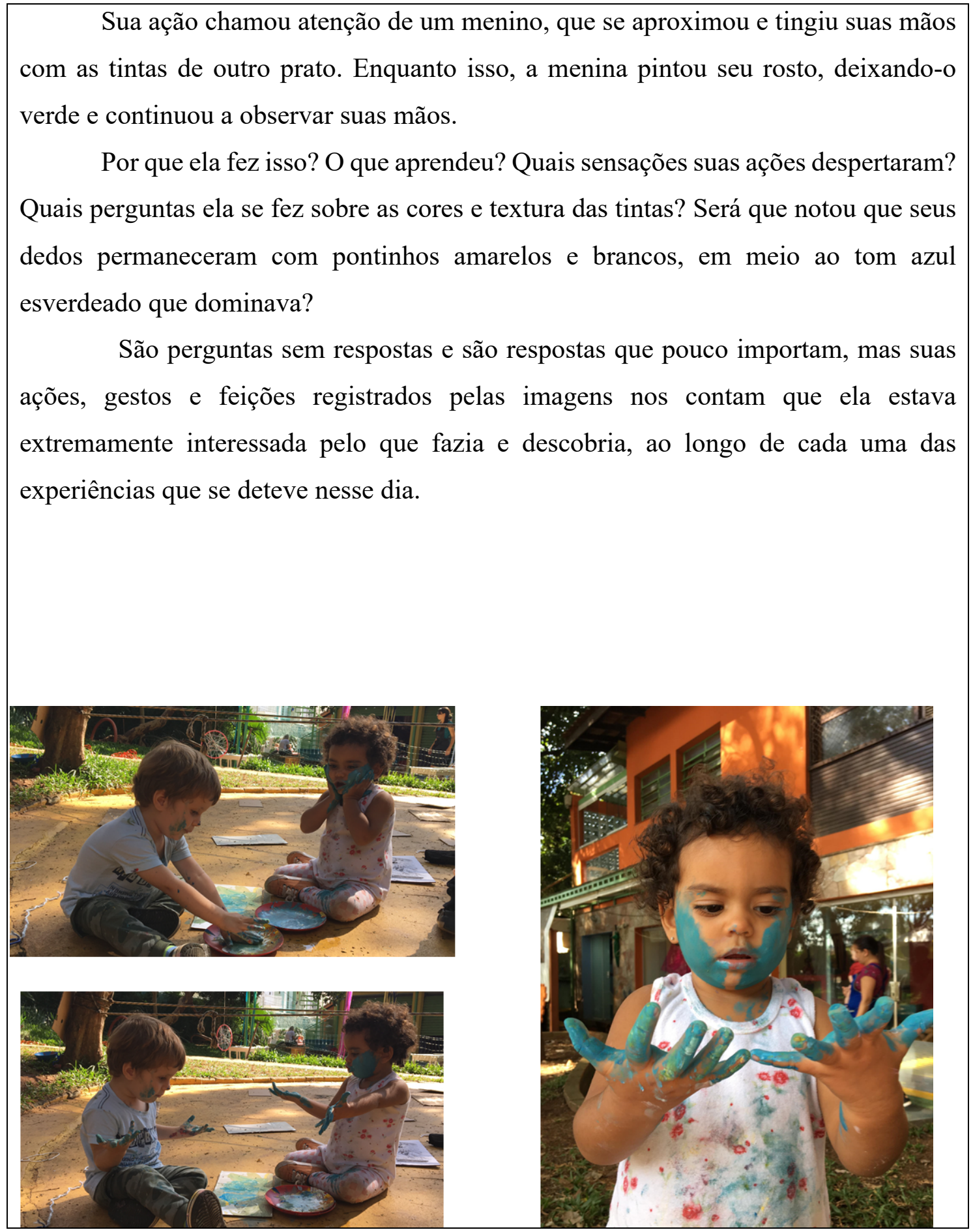

Conjunto de imagens 14 - treze imagens registradas por Leticia Pereira que ilustram a narrativa da Deriva. Imagens do acervo do espaço ekoa, 2019. Fonte: A Autora

Os materiais não estruturados, brinquedos de largo alcance e os elementos da natureza favorecem a realização de experiências diretas, manipulação, transformações e combinações, dando oportunidades de interação entre as crianças e a criação de próprias brincadeiras. 
Ao transportar pedras usando casca de árvore, por exemplo, a criança pode sentir seu peso, experimentar como melhor deve segurar a casca e qual lugar deve colocar a pedra para conseguir equilibrá-la. Ela pode criar uma configuração estética para dispor esses materiais e pode levar as pedras novamente ao pote, tendo o controle de suas ações e decisões, pelo tempo que quiser.

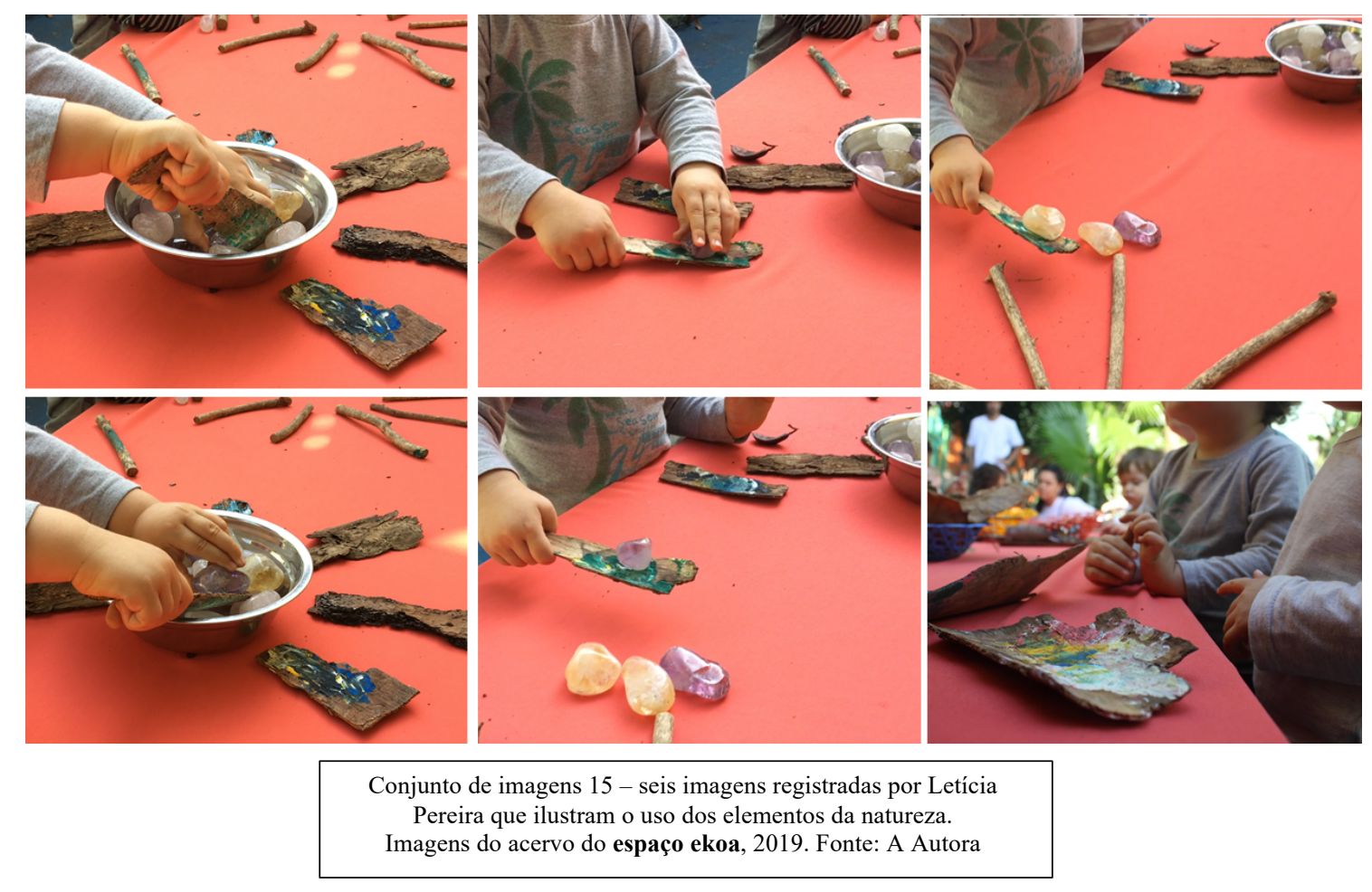

Enfim, dias organizados dessa maneira integrada, promovem boas reflexões sobre as ações no dia a dia, sobre as múltiplas possibilidades de intervenções que podem caber às educadoras, que muitas vezes apenas exercem um controle sobre as crianças, sem se colocar em conexão com o que as mobiliza e o que propulsiona na busca de conhecer o mundo.

Quanto mais as educadoras confiarem nas capacidades das crianças e as instituições de Educação Infantil se configurarem como espaços seguros e desafiadores, mais oportunidades elas terão de vivenciarem explorações espontâneas, relacionando-se de corpo inteiro com as diferentes situações, sendo guiadas pelas interferências do espaço e criando experiências pessoais, que podem ser partilhadas por trocas entre as crianças e os adultos, por diferentes formas de expressão (tais como, silêncio, choro, olhares, sons, balbucios, gestos, feições, risos, gritos ou pela comunicação oral), por convocações ou solicitações de ajuda.

Pela observação, acompanhamento das ações e por uma presença que se faz notar 
pelo modo como se colocam fisicamente (gestos, posturas e tons de voz) nas relações estabelecidas com as crianças, mais oportunidades as educadoras terão de se aproximar do que as interessa e melhores ideias, como sugere Anna Marie Holm, poderão oferecerlhes em seu dia a dia.

As crianças, por sua vez, quanto mais abertura encontrarem em seu cotidiano e mais oportunidades tiverem de estar sob os cuidados de pessoas zelosas, gentis e encorajadoras de suas ações, mais experiências, derivas, disponibilidade para aprender e de estar em relação com os outros elas terão e, com isso, poderão exercer e vivenciar plenamente seus direitos a(s) infância(s). Podendo agir, pensar, brincar, aprender, brigar, dormir, comer e viver como bebês e crianças, em seu presente e não no que um dia virão a ser.

\section{As Experiências dos Bebês}

Em seu trabalho cotidiano com bebês e crianças pequenas, a autora desta pesquisa e sua equipe de educadoras têm realizado descobertas sobre seus modos de agir e interagir com o mundo, com o conhecimento e com as pessoas. Descobriram formas menos diretivas de estabelecerem contatos com eles e de realizarem propostas.

A aproximação com os estudos da Abordagem Pikler favoreceu a consolidação de novos pontos de vista na observação de bebês. Esse fato promoveu mudanças na qualidade das interações estabelecidas durante os momentos de cuidados físicos, tornando as situações de banhos, troca de fralda, alimentação e sono, acontecimentos privilegiados para conhecer cada um deles individualmente, descobrir suas preferências e recusas. Respeitando os limites colocados, quando não desejam realizar algo e buscando maneiras gentis de convocá-los à participação, quando algo parece necessário ou possivelmente interessante para eles.

As educadoras passaram ter maior atenção às suas ações sutis, dando tempo para que os bebês respondam a uma solicitação e cuidando para que os corpos adultos não invadam os corpos infantis de forma abrupta.

As mudanças contínuas e graduais promoveram um salto de qualidade na relação estabelecida, no modo de considerá-los sujeitos ativos e participativos e contribuíram para a consolidação de uma atmosfera mais rítmica, harmônica e tranquila entre educadoras e 
crianças. As situações de alimentação, banho, trocas de fralda e sono tornaram-se momentos extremamente ricos de interação e esteticamente cuidados.

Durante as refeições, por exemplo, toda a apresentação dos alimentos, desde o preparo até o momento de servir, a organização dos espaços, com toalhas, jogos americanos, uso de louças e copos de vidro; tempo destinado a esses momentos, foram modificados e notamos que a aceitação aos novos alimentos, o tempo de provar e degustar diferentes sabores e texturas ganharam qualidade.

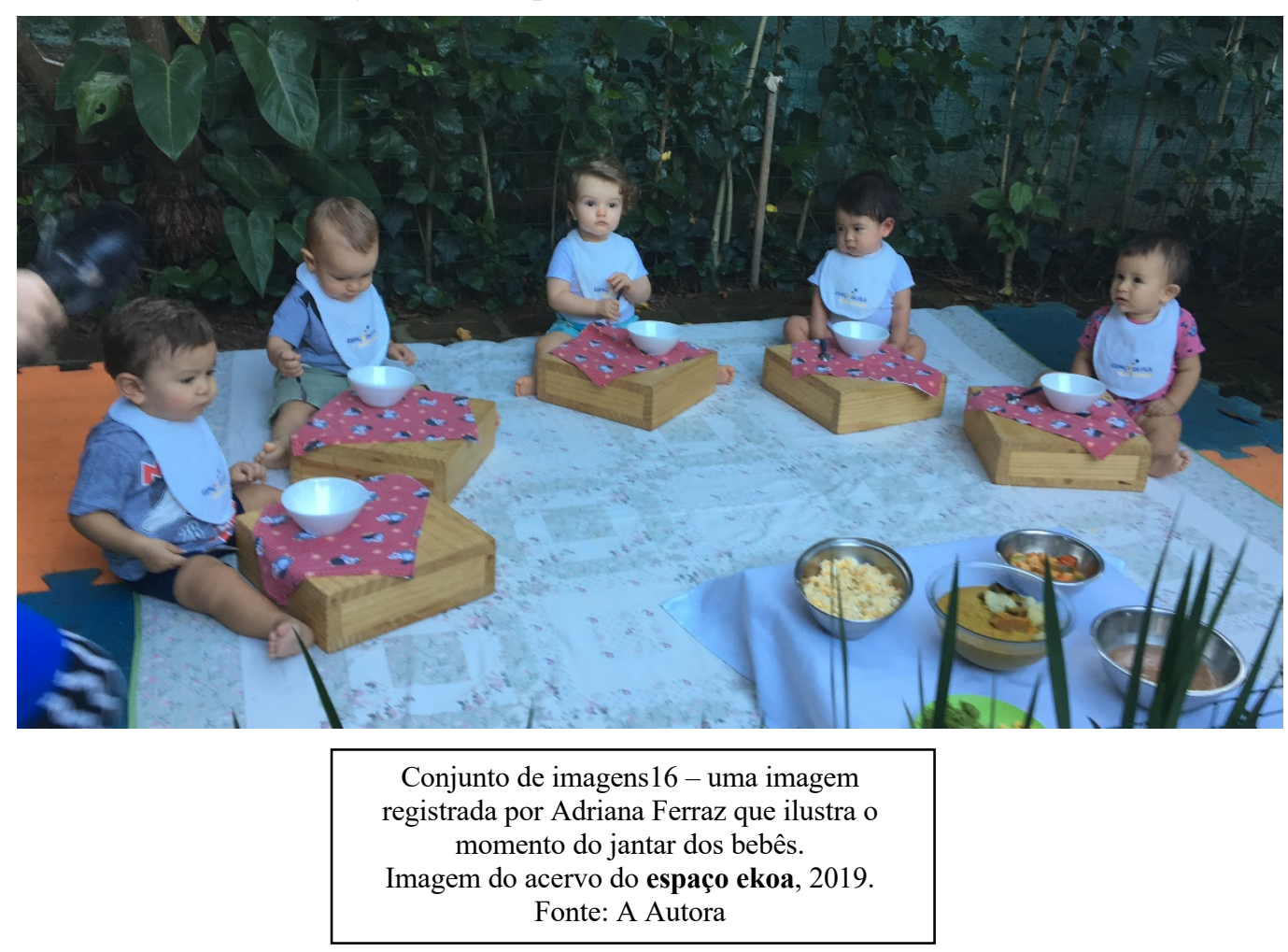

Em 2019, iniciaram-se as incursões sobre os princípios da Pedagogia-emParticipação ${ }^{18}$ que promoveram questionamentos sobre como poderia se dar a participação com bebês e de que maneira eles conseguiriam comunicar suas impressões e desejos frente a uma situação ou proposta dirigidas a eles. Em reuniões pedagógicas, foram analisadas filmagens de duas propostas de pintura com extratos de talos de verduras realizadas com as turmas de bebês do berçário e que contribuíram para repensar sobre o sentido e significado da realização de propostas como essas.

Seguem abaixo anotações da autora da pesquisa sobre algumas dessas inquietações:

18 Pedagogia-em-Participação é um modelo pedagógico para educação em creches proposto por Julia Oliveira-Formosinho e João Formosinho (2018), que está centrada em três pilares: conhecimento científico, conhecimento prático, pragmático e conhecimento ético. 
"Primeiro avaliamos duas propostas realizadas com as turmas dos bebês (manhã e tarde) do berçário.

No período da manhã, a turma era composta por apenas três bebês, um com um ano e dois meses, outro com um ano e outro com quase onze meses.

No período da tarde, a turma era composta por oito bebês, sendo a maior com um ano e quatro meses e a mais nova com cinco meses.

As propostas se assemelhavam e envolviam a exploração de substâncias feitas com tintas produzidas a partir de extratos de talos de vegetais.

Para as três crianças do período da manhã, os extratos estavam distribuídos em três potes de aço inox, sobre três tablados de espuma com papéis brancos fixados e rolinhos de pintura disponíveis.

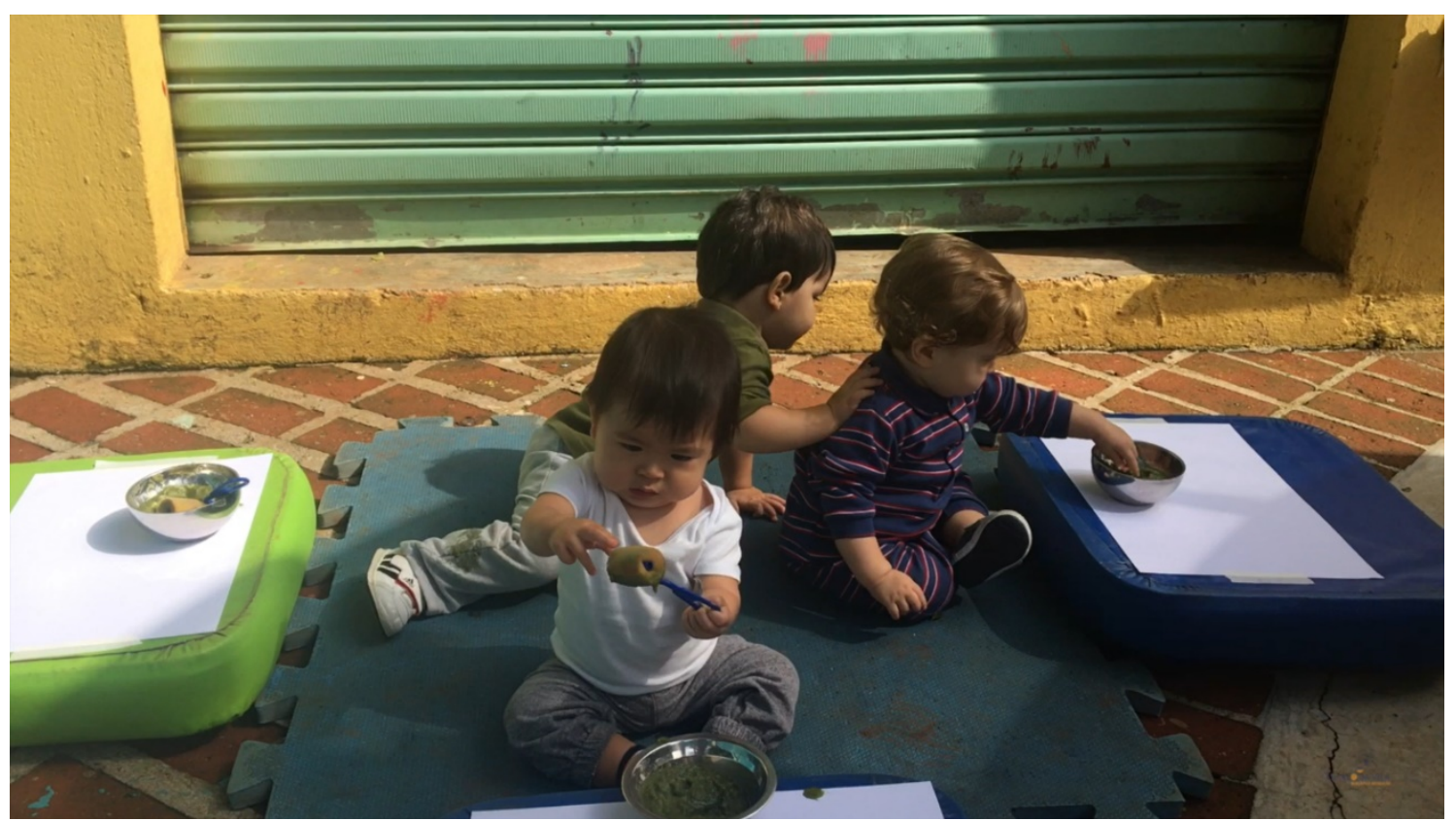

Para as crianças da tarde, os extratos foram colocados em forminhas de inox, ao lado havia formas com farinha de trigo e colheres plásticas. Esses elementos, foram colocados sobre quadrados de madeira de 20 x $20 \mathrm{~cm}$, envoltos em plásticos. 


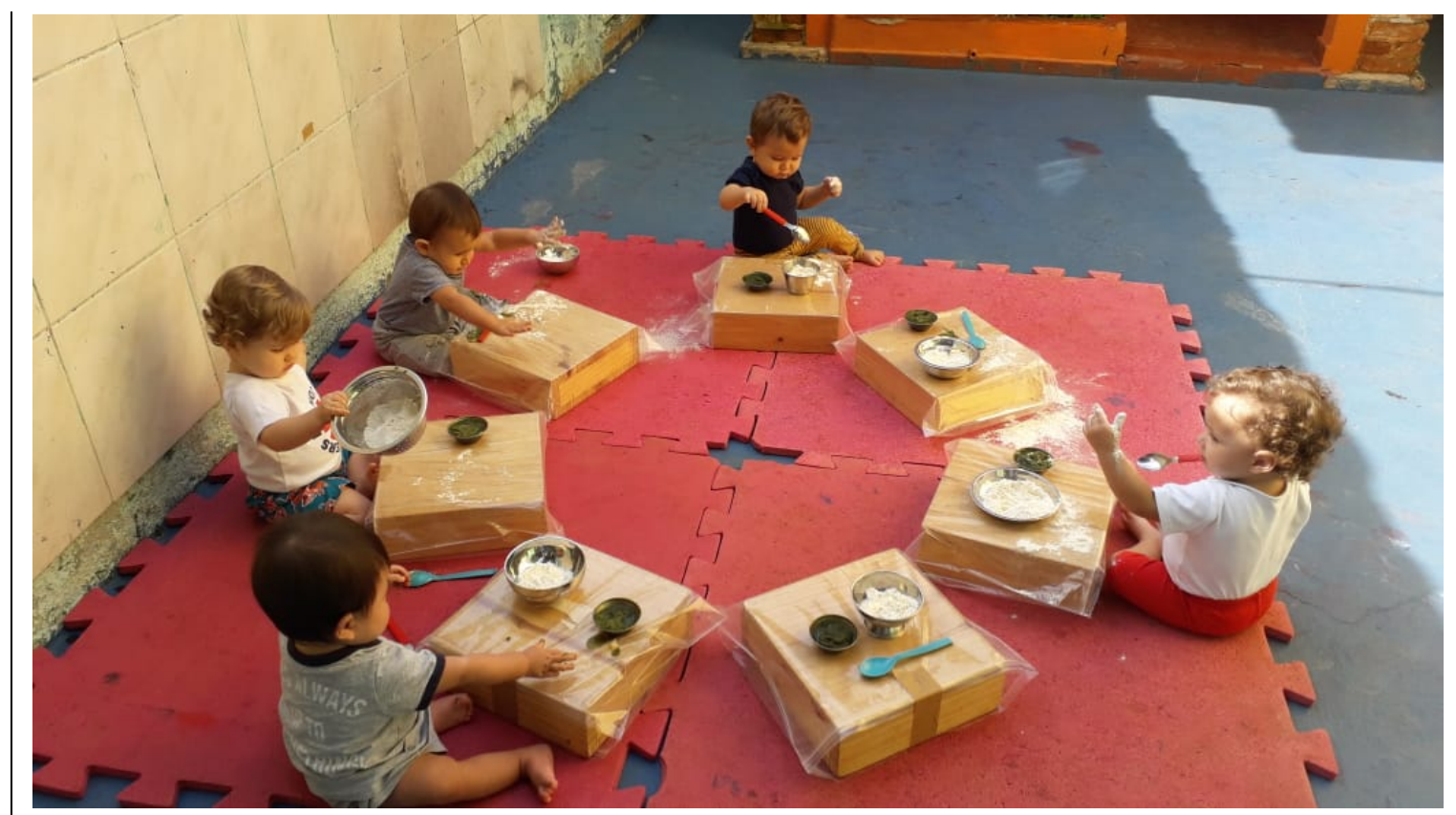

Em ambas as propostas, a intenção era deixar as crianças explorarem os materiais e observar como cada uma iria interagir com eles. Então, elas foram convidadas a seguir para o local que havia sido organizado. As que já andavam e engatinhavam foram sozinhas e as que ainda não se deslocavam com autonomia, foram no colo.

A bebê de cinco meses, não estava muito bem-disposta e foi colocada num bebê conforto, próxima ao grupo. Discutimos que precisamos pensar em melhores alternativas para garantir seu bem-estar, numa próxima situação.

Os bebês maiores, foram se aproximando dos tablados de madeira e começaram suas explorações. Alguns, permaneceram parados, olhando ao redor, outros pegaram a colher e começaram a batê-la na madeira, alguns, com movimentos aleatórios tocaram no extrato de verdura, outros na farinha.

Alguns bebês pareciam ter maior intencionalidade em suas ações, olhavam atentamente os materiais, antes de iniciarem suas explorações.

Notamos que suas reações também foram diversas. Tivemos aqueles que se mostraram muito desafiados a explorar os materiais e outros que se incomodaram ao sentir as texturas diferentes.

Os sons que emitiam também variaram: alguns choraram, outros deram gritos eufóricos, teve quem murmurou e quem chamou pela mãe, como num pedido de socorro. 


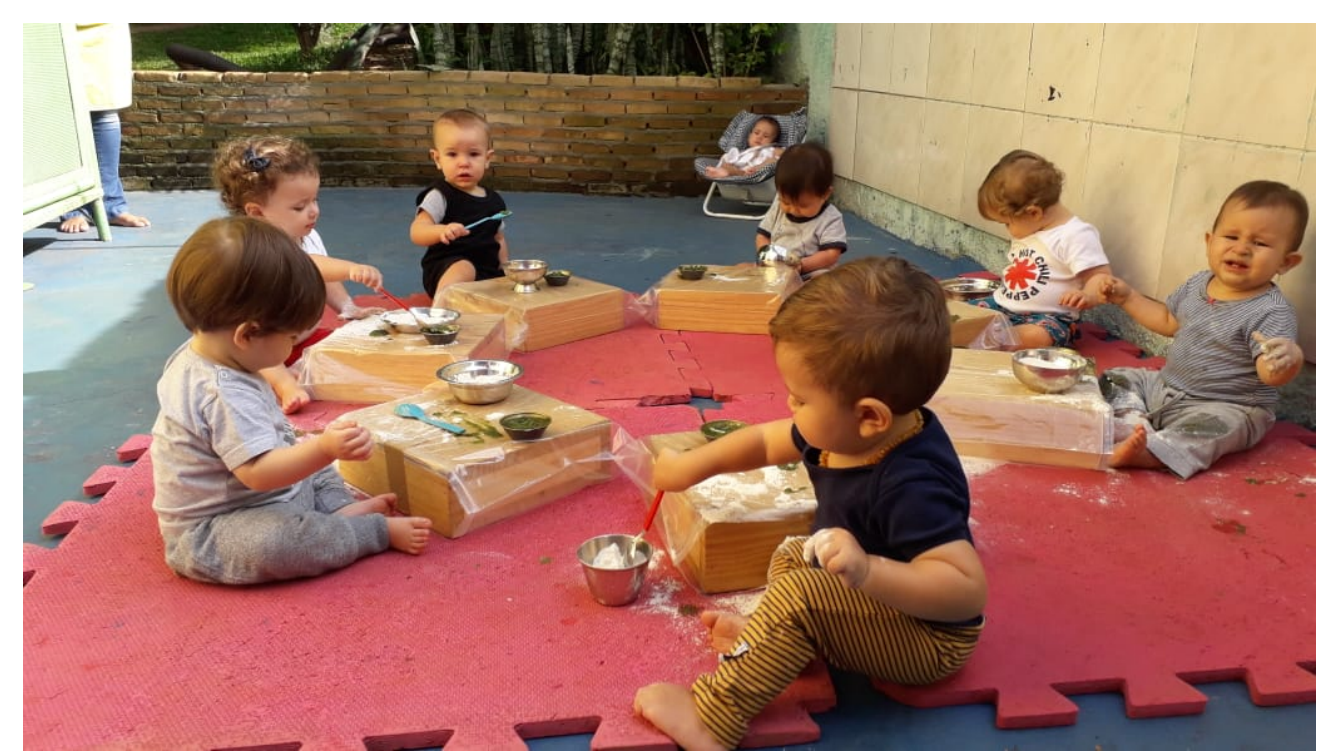

Alguns bebês, alternaram entre expressões de prazer e de estranhamento durante suas explorações, num minuto davam risadas e no minuto seguinte gritavam ou choravam e em seguida voltavam a rir.

Pouco a pouco, iam se levantando e procurando outras coisas para fazer. Mas tivemos quem permaneceu bastante tempo focado em suas explorações com esses materiais.

Os bebês do período da manhã nem tocaram na meleca. Dois deles, ficaram interessados em explorar os rolinhos de espuma: apertavam, deslizavam, balançavam ao ar, até se aproximavam do pote de meleca, mas não mergulharam as mãos ou os rolinhos neles.

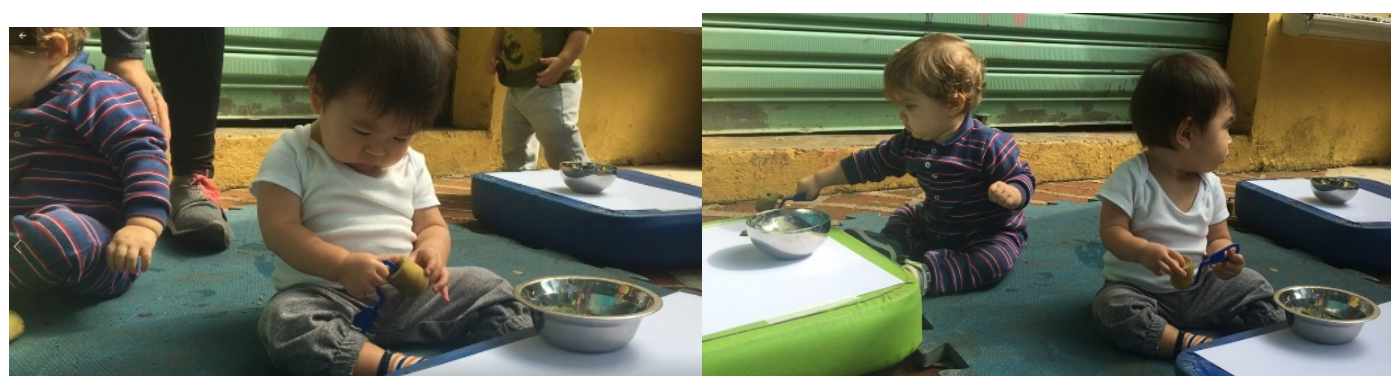

E um deles, ficou perambulando pelo ambiente e mesmo quando uma das educadoras o colocou sentado em frente ao tablado, ele se levantou, mostrando que não tinha interesse em tocar naqueles materiais. Alguns minutos depois, ele encontrou uma poça de água, sentou-se, começou a tocar na água e divertiu-se com essa brincadeira. 


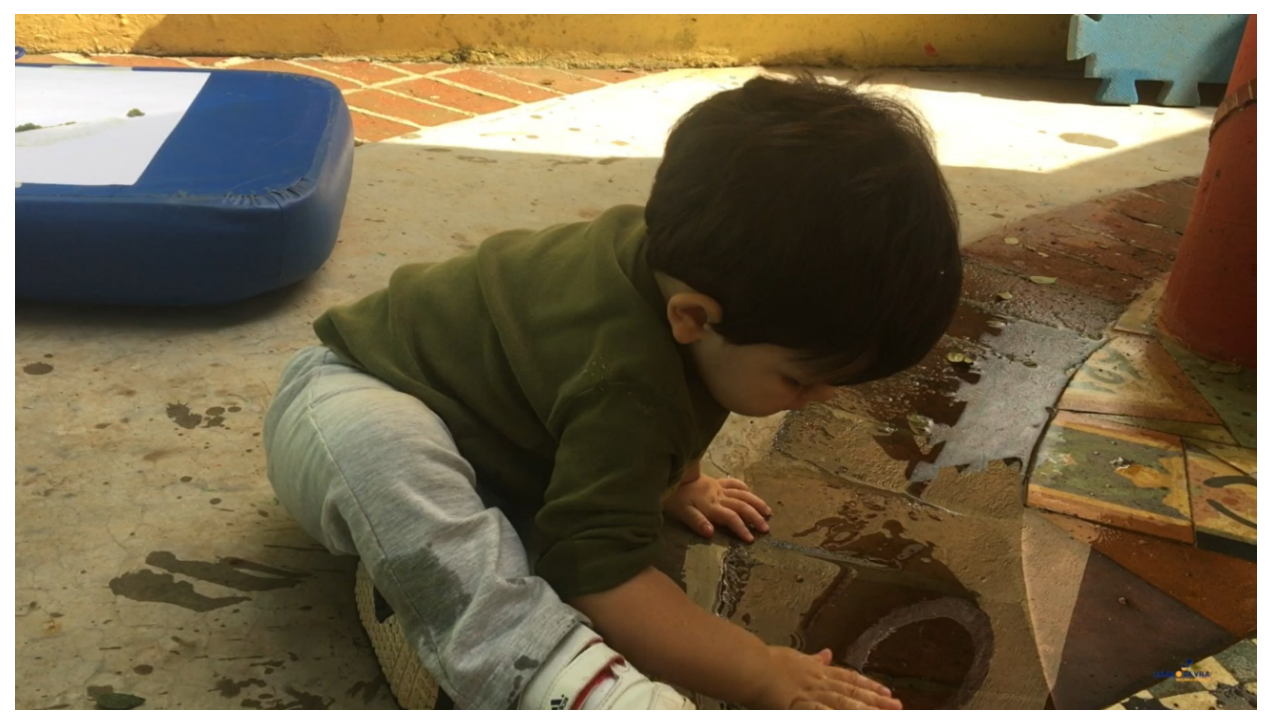

Quando conversamos sobre essas duas situações em nossa reunião, discutimos sobre seu sentido e significado tanto para as educadoras como para as crianças.

A responsável pela turma da manhã disse que se sentiu um pouco frustrada e sem saber o que fazer diante do que observou, tanto no momento em que os bebês estavam em ação, como também depois de nossa conversa.

A responsável pela turma da tarde disse que, apesar do choro de alguns dos bebês, percebeu que, mesmo os que demonstraram desconforto, quiseram permanecer por mais um tempo na exploração, num misto de prazer e repulsa.

As educadoras das outras turmas relataram que já vivenciaram situações parecidas e sugeriram que continuassem a oferecer os mesmos materiais, para que possam, após a repetição e continuidade dessas propostas, verificar se de fato elas não têm sentido para as crianças.

Consideramos que há muito a se pensar sobre essas propostas, mas focando agora na ideia da participação dos bebês, parece-nos que, a partir de ações aleatórias, eles nos mostraram seus interesses, desejos e estranhamentos - mesmo quando foram convocados a realizar algo que os adultos achavam que deveriam fazer, eles se recusaram, ou por focarem em outras explorações, ou por chorarem e se dispersarem.

Tivemos a impressão de que para alguns deles esse tipo de exploração poderá vir a ser progressivamente mais interessante e que para outros nem tanto, mas só o tempo e novas oportunidades confirmarão ou refutarão essas impressões. Porém, afirma-se que é primordial que nenhuma criança seja obrigada a fazer algo que não se sinta confortável em fazer."

(anotações realizadas após reunião pedagógica ocorrida no dia 16 de abril de 2019)

Conjunto de imagens17 - seis imagens registradas por Sabrina Mantovanni e Adriana Ferraz que ilustram os bebês em suas experimentações com os materiais de artes. Imagens do acervo do espaço ekoa, 2018. Fonte: A Autora 
Pela análise das ações dos bebês nas duas situações, ficou evidente o quanto eles se manifestaram frente às propostas, com ações de estranhamento, recusa, interesse, alternância de impressões e envolvimento em detalhes "periféricos" que fugiam ao que os adultos consideravam mais relevante naquele cenário. Tal análise, só foi possível pela possibilidade de observação, reflexão e construção de olhar que as pedagogias participativas trazem como princípios fundamentais para a realização de um trabalho de qualidade com os bebês e crianças pequenas.

Ao propor, num outro dia, o contato com as tintas naturais para os três bebês do período da manhã, a organização do espaço foi semelhante, mas as tintas foram dispostas em potes de inox de tamanhos diferentes e não foram oferecidos outros materiais como rolinhos ou pincéis. Sem esses materiais, os dois bebês menores se mostraram mais interessados em sentir as texturas das tintas, um deles mergulhou sua mão em vários potes e pareceu observar as diferentes texturas e cores que imprimia nas folhas. Outro virou dois potes de tinta sobre si e ficou experimentando com as mãos a sensação produzida, por duas vezes levou a mão à boca para experimentar o sabor, mas não ficou por muito tempo nessa exploração.

O bebê, que da outra experimentação perambulou pelo espaço e brincou com a poça de água, desta vez passeou mais um pouco, mas por três vezes levou o dedo aos potes de tinta e depois deslizou sobre as folhas.
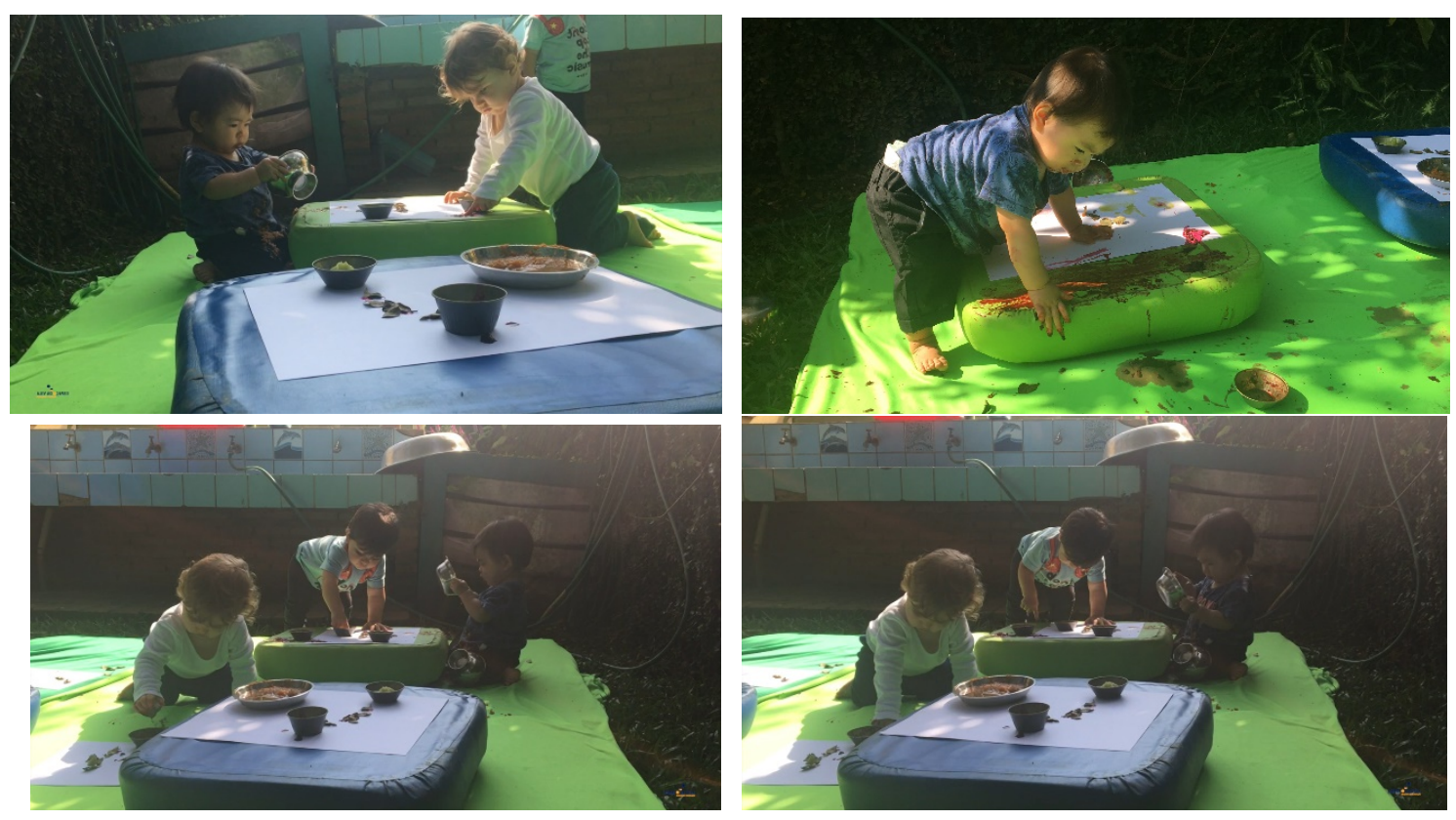

Conjunto de imagens 18 - quatro imagens registradas por Sabrina Mantovanni que ilustram os bebês em outras experimentações com os materiais de artes. Fonte: A Autora 
Ao analisar essas propostas ainda surgem dúvidas sobre o sentido de oferecê-las às crianças. Por um lado, são visíveis a calma, o interesse e atenção durante a exploração. Por outro, ressoa a crítica da Abordagem Pikler ao oferecimento de materias molhados às crianças, pelo fato de serem imprevisíveis em suas respostas e com isso, as crianças não têm controle sobre suas ações, após manuseá-los.

Por enquanto, mantém-se a organização de espaços que atraiam a atenção das crianças, mantendo-as livres para decidirem se têm interesse em explorá-los ou não. Em paralelo, as educadoras permanecem atentas para eventuais intervenções frente aos incômodos que forem manifestados. Com isso, pretende-se colher melhores informações para avaliar se tais propostas fazem sentido para elas. 


\section{CONSIDERAÇÕES FINAIS}

Por que é preciso conhecer os bebês e as crianças bem pequenas para ser uma boa educadora da primeira infância? Esta foi a questão original desta pesquisa e resultou na elucidação de alguns percursos e na elaboração de outras perguntas.

O trabalho com crianças dessa faixa etária, em sua origem, carecia de identidade própria. Durante muitos anos, esteve vinculado à assistência social e sua função primordial era oferecer um lugar de cuidado e guarda das crianças, enquanto suas mães trabalhavam. Durante muitos anos, não consideravam a necessidade de existir uma profissional especializada para realizá-lo. Somente com a LDB/96 foi instituída a obrigatoriedade de formação em nível superior para profissionais de creche e educação infantil e, desde então, vem-se constituindo a especificidade sobre seu papel.

Historicamente, a Educação Infantil, conhecida inicialmente como pré-escola, era vista como uma etapa preparatória para o ensino fundamental e a etapa do zero aos três anos seguiu o mesmo percurso, sendo considerada preparatória para os anos finais da Educação Infantil. Os bebês e crianças pequenas eram tomados por aquilo que lhes faltava e, por conta disso, acreditava-se que não havia muito a ser feito a não ser esperar pela chegada da linguagem, dos registros gráficos e de uma boa socialização para que fossem compreendidos. Seus modos de ser e estar no mundo eram pouco valorizados e o que se pretendia era instrumentalizar o seu devir.

Esta pesquisa partiu da premissa de que o caminho precisava ser outro. Isto é, ao invés de esperar pelo futuro, colocou como necessário conhecer os modos peculiares como os bebês e crianças pequenas se relacionam e entendem o mundo que os rodeia. Partiu do princípio de que seria fundamental conhecer como se relacionam coletivamente e conhecer como cada um deles, em sua singularidade, lida e compreende as suas vivências e possibilidades de se relacionar com o novo que lhes é cotidianamente apresentado.

Em 2002, quando a autora desta pesquisa começou a trabalhar com essa faixa etária, a discussão estava pautada numa busca por uma identidade educacional e voltavase à integração do cuidar e educar, em contraposição à visão assistencialista. Essa integração faz-se cada vez mais necessária, sendo preciso, porém, ressignificar a visão do cuidar para além do atendimento às demandas físicas. Cuidar é o zelo, a gentiliza que se estabelece no tom de voz, nos gestos, nas ações, nos sorrisos e no toque, é favorecer a 
humanidade das crianças. E educar não pode ser traduzido como a compilação e seleção de saberes a serem transmitidos, pois esse é um momento em que a educação deve favorecer a amplitude, não as restrições e compartimentação de ideias e fatos. É o momento de aprender sobre as práticas sociais e inserir-se nelas. A partir desse ponto de partida, esta pesquisa tratou do valor dos adultos (educadoras) se aproximarem e decodificarem como se dão suas aprendizagens e de se disponibilizarem a experimentar os pontos de vista infantis para poderem acessar melhor seus interesses e motivações.

Mas de que maneira isso é possível?

Por reconhecer a complexidade inerente ao ato de cuidar e educar, a autora sentiu a necessidade de elucidar e decodificar quem são esses sujeitos. O percurso escolhido foi partir da descrição de Piaget (1979) sobre a inteligência sensório-motora e como os bebês compreendem e se relacionam com os objetos, com o espaço e com as pessoas, ao mesmo tempo em que buscou observá-los para conhecer as minúcias e as micro ações que indicavam seu interesse por conhecer cada vez mais o que lhes era apresentado em seu cotidiano.

Para oferecer intervenções de qualidade propôs-se uma aproximação aos conceitos da Abordagem Pikler (2014) que sugerem a presença segura e interessada da educadora no contato com os bebês, ao mesmo tempo em que coloca como necessária a garantia de sua liberdade motora, a fim de que realizem novas conquistas com autonomia.

Ainda no intuito de oferecer boas intervenções por parte das educadoras, a investigação trouxe a possibilidade de as crianças serem convidadas a participar e vivenciar de diversas situações em um ambiente culturalmente enriquecido, no qual o brincar, as explorações sensoriais com diferentes objetos e materiais, as linguagens artísticas, a linguagem oral e os movimentos foram colocados como fundamentais a cada uma delas.

A todo momento, evidenciou que cada criança precisa ser compreendida em sua individualidade, pois são sujeitos únicos que possuem modos próprios de lidar com o que lhes é apresentado e precisam ter ao seu lado adultos zelosos, gentis e conectados com elas.

Partiu do princípio de que cada bebê e cada criança conta sobre si, sobre o que gosta, o que não gosta, sobre o que o(a) acalma, ou excita de forma não linear, pelo choro, pelas recusas, pelos gestos ou silêncios e propôs às educadoras a disponibilidade para 
compreender, escutar e ajudá-los(as) para que se sintam encorajados(as) a lidar com os desafios que aparecem em seu cotidiano. Desse modo, propõe que a atitude de acolhimento seja permanente e colocada como um princípio fundamental do trabalho, pois garante a segurança e bem-estar das crianças, assim como a construção do sentimento de que são bem-vindas nesse espaço coletivo que é a escola de Educação Infantil.

Coloca em destaque o papel da observação como forma da educadora descobrir o que mobiliza o interesse da(s) criança(s), tornando visível e trazendo concretude a aprendizagens e descobertas que passariam despercebidas. A partir da observação, as educadoras podem oferecer novas possibilidades e contextos à(s) sua(s) pesquisa(s).

A pesquisa destaca a valorização do brincar como um ponto central de um bom projeto pedagógico voltado à primeira infância e, para tanto, coloca como fundamental que as educadoras ofereçam bons contextos para que a brincadeira perpasse seu cotidiano e compreendam que as crianças precisam brincar, porque é pela brincadeira que elas se relacionam com o mundo e entendem o que ocorre a seu redor. As crianças pequenas apresentam seu encantamento pelo novo através do olhar constante de descoberta e surpresa, pela forma intensa como os momentos de prazer e desprazer são expressos em suas ações e pelos gestos sutis que dão pistas sobre o que fazer e propor a elas.

Nessa aproximação ao modo de pensar dos bebês e das crianças pequenas, acredita-se que as educadoras passam a compreender melhor como se dão suas aprendizagens e descobertas. E, para afinarem a interlocução com as ideias infantis, podem oferecer contextos de aprendizagens abertos, nos quais as crianças sintam-se convidadas a realizar suas explorações livremente, sem que tenham que necessariamente dar uma resposta única e previsível ao que lhes é proposto. E, por mais difícil que seja, é importante que as educadoras aceitem que muitas coisas lhes escaparão, pois os modos de compreensão infantis seguem outra lógica, nos quais as sensações e o universo simbólico criam enredos que a mente adulta não consegue mais alcançar.

Nesse sentido, faz-se necessário descobrir aquilo que ainda não sabem sobre as crianças e que se coloquem perguntas sobre o que observam, a fim de oferecer maior abertura ao cotidiano. Vale ressaltar aqui que faz parte do papel da educadora lidar com o desconforto, recuar de uma proposta, acolher o inusitado ou aguardar o tempo da criança para dar alguma resposta àquilo que ela propôs - tal como descrito no capítulo 6 , no trecho referente às experiências dos bebês em propostas de pintura. 
A pesquisa etnográfica foi trazida como uma forma de aproximação com o pensamento infantil. Sabe-se, porém, que no contexto educativo, diferente do contexto de uma pesquisa, é inviável que os adultos assumam o papel de adulto atípico tal qual sugere Corsaro, entretanto, o que se busca propor é que as educadoras experimentem frequentar locais que usualmente somente as crianças frequentam, sem colocarem restrições ou proporem intervenções a priori. A ideia é que experimentem seus pontos de vistas, procurem depreender seus interesses ou a lógica de suas ações, antes de interrompê-las com sugestões ou restrições ao que e como fazer, brincar, falar ou agir. As próprias crianças indicam caminhos a serem percorridos e cabe aos adultos experimentar seus pontos de vista, tanto para ir ao encontro de sua lógica, como para colocar-lhes contrapontos.

Os bebês e crianças pequenas são sujeitos do "aqui e agora", se relacionam com o mundo de corpo inteiro e se expressam fisicamente quando desejam realizar algo. Ainda não usam a linguagem oral como forma fundamental de expressar seus desejos e entendimentos do mundo. A fração de segundos da questão ou da ação que a criança se coloca é prolongada pelo destaque dado pelos adultos que valorizam e dão visibilidade a elas. Aqui cabe uma pergunta: será que a criança continuaria fidelizada à essa ação (pesquisa) se os adultos não mantivessem contextos recorrentes para a mesma temática? Não há como saber, mas de todo modo parece interessante pensar que o olhar do adulto para a criança pode oferecer-lhe a oportunidade de ampliar seu plano de ação e, com isso, criar condições para que ocorram novas descobertas.

As educadoras dessa faixa etária merecem ser vistas como sujeitos de ação, produtoras de conhecimento sobre a infância. Ao partirem das contribuições teóricas sobre esses sujeitos (os bebês e as crianças pequenas) - concepções sobre a infância, conhecimento epistemológico sobre eles, referenciais e reflexões sobre formas de intervenção - criam o entrelaçamento e consolidação de uma prática criativa, lúdica e reflexiva, que lida com o cotidiano e com as regularidades, não como rotinas estanques, mas como produtoras de conhecimento.

Por mais que o trabalho com essa faixa etária pareça se repetir, deve-se levar em conta que a cada ano são novos bebês e crianças que vivenciam processos pessoais e singulares de conhecer o mundo. Assim como, a cada ano, novos detalhes são percebidos, valorizados e visibilizados por educadoras que se mantém ávidas por compreender as crianças e, mesmo quando não há novidades, podem testemunhar e contribuir para suas 
conquistas genuínas e triviais, partilhando de seus encantamentos e dando suporte à busca de soluções frente às dificuldades que se apresentam.

Para finalizar, retomando a mini-história do "Menino e a Lama", pode-se dizer que o caminho percorrido pela autora para a realização desta pesquisa foi semelhante. A princípio sentia-se receosa e atraída por realizá-la. Conforme foi percorrendo os caminhos levados pela pesquisa e pelo texto, desfrutou do prazer de sentir as ideias fluírem e suas perguntas encontrarem interlocução, assim como o menino que se deliciava com a lama. E, ainda como ele, a autora buscou olhares externos quando sentia dúvidas quanto aos caminhos escolhidos. Agora, chegando ao final, sente que é momento de parar, voltar ao conforto de seu cotidiano (tomar um banho quente?), abastecida pelas experiências que o percurso acadêmico lhe proporcionou. 


\section{REFERÊNCIAS BIBLIOGRÁFICAS}

BALBI, Thiago Machado e FERRARA, Lucrécia D'Allessio. Por uma teoria psicogeográfica da comunicação In: Intexto. n. 41 jan./abr. 2018. Disponível em https://seer.ufrgs.br/index.php/intexto/article/view/69070 . Acesso em 12 jun. 2019.

BARBOSA, Maria Carmen Silveira. Práticas cotidianas na educação infantil: bases para reflexão sobre as orientações curriculares. MEC: Brasília, 2009.

BECKER, Howard S. Métodos de pesquisa em Ciências Sociais. São Paulo: Editora Hucitec. 1993.

BONDÍA, Jorge Larrosa O Enigma da infância. In: Pedagogia profana: danças, piruetas e mascaradas. Belo Horizonte: Autêntica, 2003, p. 182-198.

BONDÍA, Jorge Larrosa. Notas sobre a experiência e o saber de experiência. Revista brasileira de educação, no. 19 p. 20-28. 2002. Disponível em http://www.scielo.br/pdf/rbedu/n19/n19a02.pdf. Acesso em 14 jun. 2019.

BRASIL. Base Nacional Comum Curricular (BNCC). Educação é a base. Brasília, MEC/CONSED/UNDIME, 2017.

BRASIL. Diretrizes curriculares para educação infantil. Brasília, MEC, 2013. Disponível em: http://portal.mec.gov.br/docman/julho-2013-pdf/13677-diretrizeseducacao-basica-2013-pdf/file. Acesso em 14 jun. 2019.

BRASIL. Referencial curricular para a educação infantil. Disponível em:

http://portal.mec.gov.br/seb/arquivos/pdf/rcnei_voll.pdf;

http://portal.mec.gov.br/seb/arquivos/pdf/volume2.pdf e

http://portal.mec.gov.br/seb/arquivos/pdf/volume3.pdf. Acesso 10 fev. 2019.

BROUGÈRE, Gilles. As culturas lúdicas têm sexo, In: BROUGÈRE, G.: Brinquedo \& companhia; São Paulo: Cortez, 2000, p. 289-306.

BRUNER, Jerome. Juego, pensamiento y linguage. Disponível em http://www.arnaldomartinez.net/docencia universitaria/bruner003.pdf. Acesso em 17 abr. 2018.

BUSS-SIMÃO, Márcia. Pesquisa etnográfica com crianças pequenas: reflexões sobre o papel do pesquisador. Revista Diálogo Educação. Curitiba: v.14, n. 41, p. 37-59, jan./abr. 2014.

CARVALHO, Maria Teresa Venceslau de. A creche: um elemento a mais na constituição do sujeito. São Paulo: Instituto de Psicologia da Universidade de São Paulo, 2001 (Dissertação de mestrado).

CHOKLER, M. A história das ideias e a coerência na praxe da Atenção Precoce do Desenvolvimento Infantil. A experiência Lóczy na educação e cuidados nos primeiros 3 anos. São Paulo: OMEP/SP, 2010.

COLL, Cesar; PALACIOS, Jesus; MARCHESI, Alvaro. (orgs.). Desenvolvimento Psicológico e Educação - Psicologia Evolutiva. Porto Alegre: Artes Médicas, 1995. 
CORSARO, William A. A reprodução interpretativa no brincar ao faz-de-conta das crianças. Educação, sociedade \& cultura, n. 17, 2002, p. 113-134.

CORSARO, William A. Entrada no campo, aceitação e natureza da participação nos estudos etnográficos com crianças pequenas. Educação sociedade, Campinas, vol. 26, n. 91, p. 443-464, mai./ago. 2005. Disponível em http://www.scielo.br/pdf/es/v26n91/a08v2691. Acesso em 01 jul. 2018.

CORSO, Diana L. e CORSO, Mário. Crescer ou não crescer. In: Fadas no divã. Porto Alegre: Artmed, 2006. p. 227-242.

CRESPIN, Graciela C. A clínica precoce: contribuição ao estudo da emergência do psiquismo no bebê. In: A clínica precoce: o nascimento do humano. São Paulo: Casa do Psicólogo, 2004. p. 13-44.

CRESPIN, Graciela C. À escuta de crianças na escuta de crianças na educação infantil. $1^{\text {a }}$ ed. São Paulo: Instituto Langage/FAPESP/CNPq, 2016.

DA MATA, R. O ofício do etnólogo, ou como ter “Anthropological Blues". In: NUNES, E. O. (org.). A aventura sociológica: objetividade, paixão, improviso e método de pesquisa social. Rio de Janeiro: Zahar Editores, 1978. p. 23-35.

DE LAJONQUIÈRE, Leandro. De Piaget a Freud. Petrópolis: Vozes, 2018.

DE LAJONQUIÈRE, Leandro. Figuras do infantil. Petrópolis: Vozes, 2010.

DE LAJONQUIÈRE, Leandro. Infância e ilusão (psico) pedagógica: escritos de psicanálise e educação. Petrópolis: Vozes, 1999.

DEWEY, John. A necessidade de uma teoria da experiência e critérios de experiência. In: Experiência e educação. São Paulo: Companhia Editoria Nacional. 1979, p.13-44

FALK, Judith. (org.). Educar os três primeiros anos: a experiência em Lóczy. Araraquara: Junqueira \& Marin, 2011.

FREITAS, Anita Viudes C. e PELIZON, Maria Helena. As contribuições da experiência de Lóczy para a formação do professor de educação infantil. Disponível em https://www.novaconcursos.com.br/arquivosdigitais/erratas/14962/19273/contribuicoes-da-experiencia-de-loczy.pdf. Acesso em 01 jun. 2021.

FOCHI, Paulo. Pikler-Lóczy: a construção de uma pedagogia dos detalhes. in: OLIVEIRA-FORMOSINHO, Julia e ARAÚJO, Sara Barros. Modelos pedagógicos para a educação em creche. Porto: Porto Editora, 2018. p.181-195

GOLDSCHMIED, Elionor e JACKSON, Sonia. Educação de 0 a 3 anos: o atendimento em creche. Porto Alegre: Artmed. 2006.

GUERRA, Victor. Formas de (de) subjetivação infantil em tempo de aceleração. In: ARAGÃO, Regina Orth e ZORNIG, Silvia Abu-Jamra. Continuidade e descontinuidade no processo e subjetivação do bebê. São Paulo: Escuta, 2018. p. 166-191. 
HOLM, Anna Marie. A energia criativa natural. In: Pro-posições, vol. 15, n. I (43). p. 83-95. jan./abr.2004. Disponível em

https://periodicos.sbu.unicamp.br/ojs/index.php/proposic/article/view/8643844/11324.

Acesso em 07 jun. 2019.

HOLM, Anna Marie. Baby-art: os primeiros passos com a arte. São Paulo: MAM SP. 2007.

JACQUES, Paola Berenstein. Apologia da deriva: escritos situacionistas sobre a cidade. Rio de Janeiro: Casa da Palavra. 2003.

KISHIMOTO, Tizuko Morchida [et al]; Jogo e letramento: crianças de 6 anos no ensino fundamental. Educação e pesquisa, v. 37, $\mathrm{n}^{\circ}$ 1, p. 191-210, 2010. Disponível http://www.revistas.usp.br/ep/article/view/28279/30122 . Acesso em 14 fev. 2017.

LAEVERS, Ferre (Ed.). Well-being and involvement in care settings. A process oriented self evaluation. Beligium: Reaserch Center for Experimental Education, 2005. (http://www.kindengezin.be/img/sics-zico-maual.pdf). Acesso em 14 fev. 2017.

LAEVERS, Ferre. Fundamentos da educação experiencial: bem-estar e envolvimento na educação infantil. Estudos em avaliação educacional, São Paulo, v. 25, n. 58, mai./ago. 2014, p. 162-185. Disponível em

https://www.fcc.org.br/pesquisa/publicacoes/eae/arquivos/1930/1930.pdf. Acesso em 14 fev. 2021.

MACEDO, Lino. A perspectiva de Piaget.s/d. Disponível em http://www.crmariocovas.sp.gov.br/pdf/ideias_02_p047-051_c.pdf. Acesso em 26 mar. 2021.

MARIN, Isabel da Silva Kahn. A função simbolizante da creche no processo de simbolização do bebê. A conquista do eu e do mundo. In: ARAGÃO, Regina Orth e ZORNIG, Silvia Abu-Jamra. Continuidade e descontinuidade no processo e subjetivação do bebê. São Paulo: Escuta, 2018, p.123-142.

MEIRINHOS, Manuel e OSÓRIO, António. O estudo de caso como estratégia de investigação em educação Revista de educação, Vol 2 (2). Inovação, Investigação em Educação, 2010.

OLIVEIRA-FORMOSINHO, Júlia e ARAÚJO, Sara Barros. Modelos pedagógicos para educação em creche. Porto: Porto Editora, 2018.

OLIVEIRA-FORMOSINHO, Júlia e PASCAL, Christine. Documentação pedagógica e avaliação na educação infantil. Porto Alegre: Penso, 2018.

PIAGET, Jean. A construção do real na criança. Rio de Janeiro: Zahar, 1979.

PIAGET, Jean. A formação do símbolo na criança. Rio de janeiro: Zahar, 1975.

PIAGET, Jean. A representação do mundo na criança. São Paulo: Ideias e Letras, 2005. 
PIAGET, Jean. Inteligencia y afectividad. Buenos Aires: Aique Grupo Editor. Disponível em:

http://materiadeapoioaotcc.pbworks.com/f/PIAGET+JEAN+INTELIGENCIA++Y+AF ECTIVIDAD.pdf. Acesso em 20 jul. 2019.

PIAGET, Jean. Seis estudos de psicologia. Rio de Janeiro: Forense-Universitária, 1973.

SABOIA, Camila. O papel do bebê no processo de acesso à subjetivação. Estilos da clínica: revista sobre a infância com problemas. Ano XI, n. 21, $2^{\circ}$. semestre 2006, p.186-195.

TRINDADE, André. A criança e seu corpo: gesto e identidade. In: Caminhos para uma Aliança pela Infância. São Paulo, 2003. Porto Alegre: Penso, 2021.

VECCHI, Vea. As cem linguagens em mini-histórias contadas por professoras e crianças de Reggio Emilia. São Paulo: Penso, 2020.

VYGOTSKII, Lev Semenovich. Linguagem, desenvolvimento e aprendizagem. Tradução Maria da Penha Villalobos. São Paulo: Ícone, 2010 (Coleção Educação Crítica).

WINNICOTT, Donald Woods. A criança e seu mundo. São Paulo: Zahar, 1982.

WINNICOTT, Donald Woods. A observação de bebês em uma situação estabelecida. In: Da pediatria a psicanálise. Rio de Janeiro: Imago, 2000, p. 139-164.

WINNICOTT, Donald Woods. Desenvolvimento emocional primitivo. In: Da pediatria a psicanálise. Rio de Janeiro: Imago, 2000, p. 218-232.

WINNICOTT, Donald Woods. O brincar e a realidade. Rio de Janeiro: Imago, 1975 


\title{
ANEXOS - TERMO DE CONSENTIMENTO E LIVRE ESCLARECIDO - CRIANÇAS
}

\author{
Termo de Consentimento Livre e Esclarecido
}

\begin{abstract}
Eu, Gulionas yupli Kawade.
RG $258+71864-x$, declaro saber da participação de meu/minha filho/a Enzo Ryo Kawada na pesquisa As especificidades da educadora de 0 a 3 anos - a construção de um novo papel desenvolvida junto à Faculdade de Educação da Universidade de São Paulo pelo/a pesquisador/a Ana Paula Yazbek, orientado/a por Rosa Iavelberg os/as quais podem ser contatados/as pelo e-mail anayazbek@usp.br ou rosaiave@usp.br ou telefone 11 99666-5612

O presente trabalho tem por objetivos: analisar o papel das educadoras dos bebês e das crianças pequenas e os instrumentos utilizados são: imagens e relatos de práticas. Compreendo que tenho liberdade de retirar o meu consentimento em qualquer fase da pesquisa, sem penalização alguma. A qualquer momento, posso buscar maiores esclarecimentos, inclusive relativos à metodologia do trabalho. Os/as responsáveis pela pesquisa garantem o sigilo, assegurando a privacidade dos sujeitos quanto aos dados envolvidos na pesquisa. Declaro compreender que as informações obtidas só podem ser usadas para fins científicos, de acordo com a ética na pesquisa, e que essa participação não inclui nenhum tipo de pagamento.
\end{abstract}

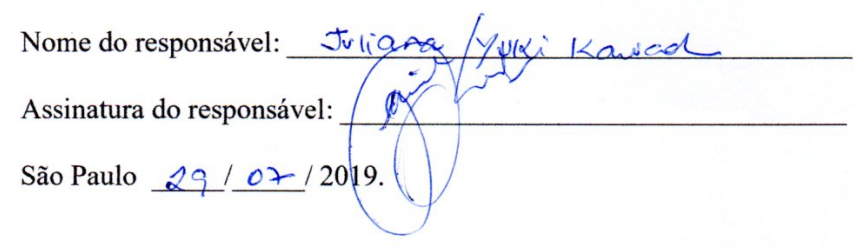

\section{Termo de Consentimento Livre e Esclarecido}

Eu, Livio quidi de Jusur

RG $44232226-4$, declaro saber da participação de meu/minha filho/a Guilherme Guidi Aulicino na pesquisa As especificidades da educadora de 0 a 3 anos - a construção de um novo papel desenvolvida junto à Faculdade de Educação da Universidade de São Paulo pelo/a pesquisador/a Ana Paula Yazbek, orientado/a por Rosa Iavelberg os/as quais podem ser contatados/as pelo e-mail anayazbek@usp.br ou rosaiave@usp.br ou telefone 11 99666-5612

O presente trabalho tem por objetivos: analisar o papel das educadoras dos bebês e das crianças pequenas e os instrumentos utilizados são: imagens e relatos de práticas. Compreendo que tenho liberdade de retirar o meu consentimento em qualquer fase da pesquisa, sem penalização alguma. A qualquer momento, posso buscar maiores esclarecimentos, inclusive relativos à metodologia do trabalho. Os/as responsáveis pela pesquisa garantem o sigilo, assegurando a privacidade dos sujeitos quanto aos dados envolvidos na pesquisa. Declaro compreender que as informações obtidas só podem ser usadas para fins científicos, de acordo com a ética na pesquisa, e que essa participação não inclui nenhum tipo de pagamento.

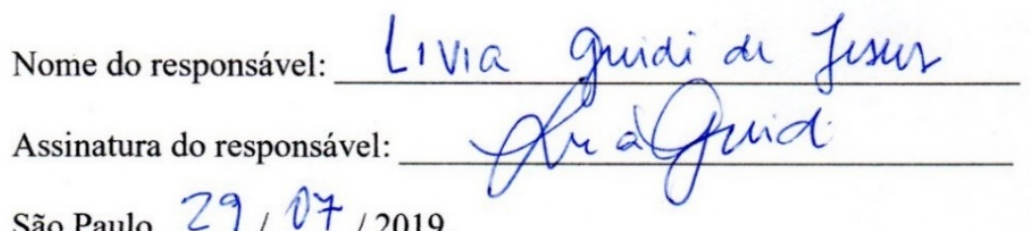

São Paulo 29,07/2019. 
Eu, LORENA PONTES COLARES DOS REIS

RG 2001010456049 , declaro saber da participação de meu/minha filho/a Isabela Colares dos Reis na pesquisa As especificidades da educadora de 0 a 3 anos - a construção de um novo papel desenvolvida junto à Faculdade de Educação da Universidade de São Paulo pelo/a pesquisador/a Ana Paula Yazbek, orientado/a por Rosa Iavelberg os/as quais podem ser contatados/as pelo e-mail anayazbek@usp.br ou rosaiave@usp.br ou telefone 11 99666-5612

O presente trabalho tem por objetivos: analisar o papel das educadoras dos bebês e das crianças pequenas e os instrumentos utilizados são: imagens e relatos de práticas. Compreendo que tenho liberdade de retirar o meu consentimento em qualquer fase da pesquisa, sem penalização alguma. A qualquer momento, posso buscar maiores esclarecimentos, inclusive relativos à metodologia do trabalho. Os/as responsáveis pela pesquisa garantem o sigilo, assegurando a privacidade dos sujeitos quanto aos dados envolvidos na pesquisa. Declaro compreender que as informações obtidas só podem ser usadas para fins científicos, de acordo com a ética na pesquisa, e que essa participação não inclui nenhum tipo de pagamento.

Nome do responsável: LORENA PONTES COLARES DOS RLTS

Assinatura do responsável: Loorena p. Colares dos Reis

São Paulo $29 / 07 / 2019$.

\section{Termo de Consentimento Livre e Esclarecido}

Eu, meviono mendes Mibion

RG 34. $300779-4$, declaro saber da participação de meu/minha filho/a João

Milbich Leite de Barros na pesquisa As especificidades da educadora de 0 a 3 anos - a

construção de um novo papel desenvolvida junto à Faculdade de Educação da Universidade de São Paulo pelo/a pesquisador/a Ana Paula Yazbek, orientado/a por Rosa Iavelberg os/as quais podem ser contatados/as pelo e-mail anayazbek@usp.br ou rosaiave@usp.br ou telefone 11 99666-5612

O presente trabalho tem por objetivos: analisar o papel das educadoras dos bebês e das crianças pequenas e os instrumentos utilizados são: imagens e relatos de práticas. Compreendo que tenho liberdade de retirar o meu consentimento em qualquer fase da pesquisa, sem penalização alguma. A qualquer momento, posso buscar maiores esclarecimentos, inclusive relativos à metodologia do trabalho. Os/as responsáveis pela pesquisa garantem o sigilo, assegurando a privacidade dos sujeitos quanto aos dados envolvidos na pesquisa. Declaro compreender que as informações obtidas só podem ser usadas para fins científicos, de acordo com a ética na pesquisa, e que essa participação não inclui nenhum tipo de pagamento.

Nome do responsável: morrone Mendes mebich

Assinatura do responsável: infiebch

São Paulo $29 / 07 / 2019$. 
Eu, Paula hadeira Colonelli

RG $28.017 .259^{-x}$, declaro saber da participação de meu/minha filho/a José Colonelli Galvani na pesquisa As especificidades da educadora de 0 a 3 anos - a construção de um novo papel desenvolvida junto à Faculdade de Educação da Universidade de São Paulo pelo/a pesquisador/a Ana Paula Yazbek, orientado/a por Rosa Iavelberg os/as quais podem ser contatados/as pelo e-mail anayazbek@usp.br ou rosaiave@usp.br ou telefone 11 99666-5612

$\mathrm{O}$ presente trabalho tem por objetivos: analisar o papel das educadoras dos bebês e das crianças pequenas e os instrumentos utilizados são: imagens e relatos de práticas. Compreendo que tenho liberdade de retirar o meu consentimento em qualquer fase da pesquisa, sem penalização alguma. A qualquer momento, posso buscar maiores esclarecimentos, inclusive relativos à metodologia do trabalho. Os/as responsáveis pela pesquisa garantem o sigilo, assegurando a privacidade dos sujeitos quanto aos dados envolvidos na pesquisa. Declaro compreender que as informações obtidas só podem ser usadas para fins científicos, de acordo com a ética na pesquisa, e que essa participação não inclui nenhum tipo de pagamento.

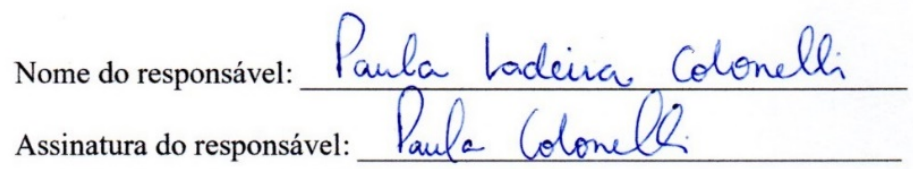

São Paulo $29 \quad 107 / 2019$.

\section{Termo de Consentimento Livre e Esclarecido}

Eu, Renata G. F. C. Muniy

RG 25.965 .347 .8 , declaro saber da participação de meu/minha filho/a Lucas Campanati Muniz na pesquisa As especificidades da educadora de 0 a 3 anos - a construção de um novo papel desenvolvida junto à Faculdade de Educação da Universidade de São Paulo pelo/a pesquisador/a Ana Paula Yazbek, orientado/a por Rosa Iavelberg os/as quais podem ser contatados/as pelo e-mail anayazbek@usp.br ou rosaiave@usp.br ou telefone 11 99666-5612

O presente trabalho tem por objetivos: analisar o papel das educadoras dos bebês e das crianças pequenas e os instrumentos utilizados são: imagens e relatos de práticas. Compreendo que tenho liberdade de retirar o meu consentimento em qualquer fase da pesquisa, sem penalização alguma. A qualquer momento, posso buscar maiores esclarecimentos, inclusive relativos à metodologia do trabalho. Os/as responsáveis pela pesquisa garantem o sigilo, assegurando a privacidade dos sujeitos quanto aos dados envolvidos na pesquisa. Declaro compreender que as informações obtidas só podem ser usadas para fins científicos, de acordo com a ética na pesquisa, e que essa participação não inclui nenhum tipo de pagamento.

Nome do responsável: Keuata g.F.C. huniz

Assinatura do responsável: Nuralal Campanahi)

São Paulo 29 / 07 / 2019. 
Termo de Consentimento Livre e Esclarecido

Eu, MAIRA NUNES

RG $60.6+7 \cdot 163 \cdot 3$, declaro saber da participação de meu/minha filho/a Luisa

Nunes Assad na pesquisa As especificidades da educadora de 0 a 3 anos - a construção de um novo papel desenvolvida junto à Faculdade de Educação da Universidade de São Paulo pelo/a pesquisador/a Ana Paula Yazbek, orientado/a por Rosa Iavelberg os/as quais podem ser contatados/as pelo e-mail anayazbek@usp.br ou rosaiave@usp.br ou telefone 11 99666-5612

O presente trabalho tem por objetivos: analisar o papel das educadoras dos bebês e das crianças pequenas e os instrumentos utilizados são: imagens e relatos de práticas. Compreendo que tenho liberdade de retirar o meu consentimento em qualquer fase da pesquisa, sem penalização alguma. A qualquer momento, posso buscar maiores esclarecimentos, inclusive relativos à metodologia do trabalho. Os/as responsáveis pela pesquisa garantem o sigilo, assegurando a privacidade dos sujeitos quanto aos dados envolvidos na pesquisa. Declaro compreender que as informações obtidas só podem ser usadas para fins científicos, de acordo com a ética na pesquisa, e que essa participação não inclui nenhum tipo de pagamento.

Nome do responsável: MAIRA NUNES

Assinatura do responsável:

São Paulo $30 / 07 / 2019$.

\section{Termo de Consentimento Livre e Esclarecido}

\section{Eu, Bruna cantergiani martinely}

RG 24.378 .5471 , declaro saber da participação de meu/minha filho/a Marcelo Cantergiani Martinelli na pesquisa As especificidades da educadora de 0 a 3 anos - a construção de um novo papel desenvolvida junto à Faculdade de Educação da Universidade de São Paulo pelo/a pesquisador/a Ana Paula Yazbek, orientado/a por Rosa Iavelberg os/as quais podem ser contatados/as pelo e-mail anayazbek@usp.br ou rosaiave@usp.br ou telefone 11 99666-5612

O presente trabalho tem por objetivos: analisar o papel das educadoras dos bebês e das crianças pequenas e os instrumentos utilizados são: imagens e relatos de práticas. Compreendo que tenho liberdade de retirar o meu consentimento em qualquer fase da pesquisa, sem penalização alguma. A qualquer momento, posso buscar maiores esclarecimentos, inclusive relativos à metodologia do trabalho. Os/as responsáveis pela pesquisa garantem o sigilo, assegurando a privacidade dos sujeitos quanto aos dados envolvidos na pesquisa. Declaro compreender que as informações obtidas só podem ser usadas para fins científicos, de acordo com a ética na pesquisa, e que essa participação não inclui nenhum tipo de pagamento.

Nome do responsável: Bruma Contergiahi maitmelli

Assinatura do responsável: Bl maiturees

São Paulo $29 / 07 / 2019$. 


\section{Termo de Consentimento Livre e Esclarecido}

Eu, Vanessa de siber.

RG $34.992 . \sqrt{45}-2$, declaro saber da participação de meu/minha filho/a Melissa Almeida Eloy Pereira na pesquisa As especificidades da educadora de 0 a 3 anos - a construção de um novo papel desenvolvida junto à Faculdade de Educação da Universidade de São Paulo pelo/a pesquisador/a Ana Paula Yazbek, orientado/a por Rosa Iavelberg os/as quais podem ser contatados/as pelo e-mail anayazbek@usp.br ou rosaiave@usp.br ou telefone 11 99666-5612

$\mathrm{O}$ presente trabalho tem por objetivos: analisar o papel das educadoras dos bebês e das crianças pequenas e os instrumentos utilizados são: imagens e relatos de práticas. Compreendo que tenho liberdade de retirar o meu consentimento em qualquer fase da pesquisa, sem penalização alguma. A qualquer momento, posso buscar maiores esclarecimentos, inclusive relativos à metodologia do trabalho. Os/as responsáveis pela pesquisa garantem o sigilo, assegurando a privacidade dos sujeitos quanto aos dados envolvidos na pesquisa. Declaro compreender que as informações obtidas só podem ser usadas para fins científicos, de acordo com a ética na pesquisa, e que essa participação não inclui nenhum tipo de pagamento.

Nome do responsável: Vamwso slmide de Siba.

Assinatura do responsável: Vomusso $\Delta$. da she

São Paulo 29/07/2019.

\section{Termo de Consentimento Livre e Esclarecido}

Eu, TAGO HADDAD

RG $25045258-3$, declaro saber da participação de meu/minha filho/a Nina Eretzky Haddad na pesquisa As especificidades da educadora de 0 a 3 anos - a construção de um novo papel desenvolvida junto à Faculdade de Educação da Universidade de São Paulo pelo/a pesquisador/a Ana Paula Yazbek, orientado/a por Rosa Iavelberg os/as quais podem ser contatados/as pelo e-mail anayazbek@usp.br ou rosaiave@usp.br ou telefone 11 99666-5612

O presente trabalho tem por objetivos: analisar o papel das educadoras dos bebês e das crianças pequenas e os instrumentos utilizados são: imagens e relatos de práticas. Compreendo que tenho liberdade de retirar o meu consentimento em qualquer fase da pesquisa, sem penalização alguma. A qualquer momento, posso buscar maiores esclarecimentos, inclusive relativos à metodologia do trabalho. Os/as responsáveis pela pesquisa garantem o sigilo, assegurando a privacidade dos sujeitos quanto aos dados envolvidos na pesquisa. Declaro compreender que as informações obtidas só podem ser usadas para fins científicos, de acordo com a ética na pesquisa, e que essa participação não inclui nenhum tipo de pagamento.

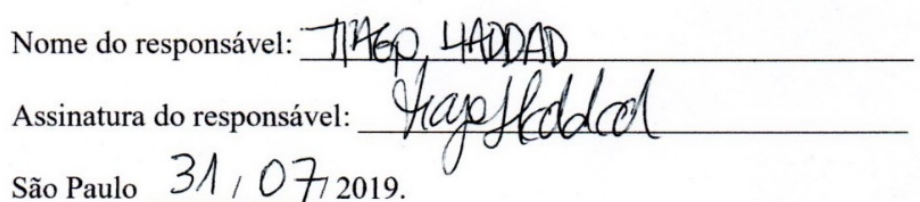




\section{Termo de Consentimento Livre e Esclarecido}

Eu, Clename Jena Otukha

RG $459+6802-5$, declaro saber da participação de meu/minha filho/a Tereza

Chieregate Otsuka na pesquisa As especificidades da educadora de 0 a 3 anos - a

construção de um novo papel desenvolvida junto à Faculdade de Educação da Universidade de São Paulo pelo/a pesquisador/a Ana Paula Yazbek, orientado/a por Rosa Iavelberg os/as quais podem ser contatados/as pelo e-mail anayazbek@usp.br ou rosaiave@usp.br ou telefone 11 99666-5612

O presente trabalho tem por objetivos: analisar o papel das educadoras dos bebês e das crianças pequenas e os instrumentos utilizados são: imagens e relatos de práticas. Compreendo que tenho liberdade de retirar o meu consentimento em qualquer fase da pesquisa, sem penalização alguma. A qualquer momento, posso buscar maiores esclarecimentos, inclusive relativos à metodologia do trabalho. Os/as responsáveis pela pesquisa garantem o sigilo, assegurando a privacidade dos sujeitos quanto aos dados envolvidos na pesquisa. Declaro compreender que as informações obtidas só podem ser usadas para fins científicos, de acordo com a ética na pesquisa, e que essa participação não inclui nenhum tipo de pagamento.

Nome do responsável: Clesumbe Utume

Assinatura do responsável:

São Paulo $29 / 07 / 2019$.

Anexos - Termo de Consentimento e Livre Esclarecido - Educadoras

\section{Termo de Consentimento Livre e Esclarecido}

Concordo em participar, como voluntário/a, da pesquisa intitulada As especificidades da educadora de 0 a 3 anos - a construção de um novo papel desenvolvida junto à Faculdade de Educação da Universidade de São Paulo pelo/a pesquisador/a Ana Paula Yazbek, orientado/a por Rosa Iavelberg os/as quais podem ser contatados/as pelo e-mail anayazbek@usp.br ou rosaiave@usp.br ou telefone 11 99666-5612

O presente trabalho tem por objetivos: analisar o papel das educadoras dos bebês e das crianças pequenas e os instrumentos utilizados são: imagens e relatos de práticas. Minha participação consistirá em contribuir com registros e anotações para elaboração dos relatos de prática. Compreendo que esse estudo possui finalidade de pesquisa, e que os dados obtidos serão divulgados seguindo as diretrizes éticas da pesquisa, assegurando, assim, minha privacidade. Sei que posso retirar meu consentimento quando eu quiser, e que não receberei nenhum pagamento por essa participação.

Nome: Fabiana Rangel Tófolo

Assinatura:

São Paulo $01 / 08 / 2019$. 


\section{Termo de Consentimento Livre e Esclarecido}

Concordo em participar, como voluntário/a, da pesquisa intitulada As especificidades da educadora de 0 a 3 anos - a construção de um novo papel desenvolvida junto à Faculdade de Educação da Universidade de São Paulo pelo/a pesquisador/a Ana Paula Yazbek, orientado/a por Rosa Iavelberg os/as quais podem ser contatados/as pelo e-mail anayazbek@usp.br ou rosaiave@usp.br ou telefone 11 99666-5612

O presente trabalho tem por objetivos: analisar o papel das educadoras dos bebês e das crianças pequenas e os instrumentos utilizados são: imagens e relatos de práticas. Minha participação consistirá em contribuir com registros e anotações para elaboração dos relatos de prática. Compreendo que esse estudo possui finalidade de pesquisa, e que os dados obtidos serão divulgados seguindo as diretrizes éticas da pesquisa, assegurando, assim, minha privacidade. Sei que posso retirar meu consentimento quando eu quiser, e que não receberei nenhum pagamento por essa participação.

Nome: Heloisa Trigo das Chagas Costa

Assinatura: LNecira Luge das Crogas Corta

São Paulo 29/07/2019.

\section{Termo de Consentimento Livre e Esclarecido}

Concordo em participar, como voluntário/a, da pesquisa intitulada As especificidades da educadora de 0 a 3 anos - a construção de um novo papel desenvolvida junto à Faculdade de Educação da Universidade de São Paulo pelo/a pesquisador/a Ana Paula Yazbek, orientado/a por Rosa Iavelberg os/as quais podem ser contatados/as pelo e-mail anayazbek@usp.br ou rosaiave@usp.br ou telefone 11 99666-5612

$\mathrm{O}$ presente trabalho tem por objetivos: analisar o papel das educadoras dos bebês e das crianças pequenas e os instrumentos utilizados são: imagens e relatos de práticas. Minha participação consistirá em contribuir com registros e anotações para elaboração dos relatos de prática. Compreendo que esse estudo possui finalidade de pesquisa, e que os dados obtidos serão divulgados seguindo as diretrizes éticas da pesquisa, assegurando, assim, minha privacidade. Sei que posso retirar meu consentimento quando eu quiser, e que não receberei nenhum pagamento por essa participação.

Nome: Letícia de Souza Durval Pereira

Assinatura: Lerialouzaterine

São Paulo $29 \quad 107 / 2019$. 


\section{Termo de Consentimento Livre e Esclarecido}

Concordo em participar, como voluntário/a, da pesquisa intitulada As especificidades da educadora de 0 a 3 anos - a construção de um novo papel desenvolvida junto à Faculdade de Educação da Universidade de São Paulo pelo/a pesquisador/a Ana Paula Yazbek, orientado/a por Rosa Iavelberg os/as quais podem ser contatados/as pelo e-mail anayazbek@usp.br ou rosaiave@usp.br ou telefone $1199666-5612$

O presente trabalho tem por objetivos: analisar o papel das educadoras dos bebês e das crianças pequenas e os instrumentos utilizados são: imagens e relatos de práticas. Minha participação consistirá em contribuir com registros e anotações para elaboração dos relatos de prática. Compreendo que esse estudo possui finalidade de pesquisa, e que os dados obtidos serão divulgados seguindo as diretrizes éticas da pesquisa, assegurando, assim, minha privacidade. Sei que posso retirar meu consentimento quando eu quiser, e que não receberei nenhum pagamento por essa participação.

Nome: Márcia Pereira de Oliveira

Assinatura:

São Paulo $29 / 07 / 2019$.

\section{Termo de Consentimento Livre e Esclarecido}

Concordo em participar, como voluntário/a, da pesquisa intitulada As especificidades da educadora de 0 a 3 anos - a construção de um novo papel desenvolvida junto à Faculdade de Educação da Universidade de São Paulo pelo/a pesquisador/a Ana Paula Yazbek, orientado/a por Rosa Iavelberg os/as quais podem ser contatados/as pelo e-mail anayazbek@usp.br ou rosaiave@usp.br ou telefone 11 99666-5612

$\mathrm{O}$ presente trabalho tem por objetivos: analisar o papel das educadoras dos bebês e das crianças pequenas e os instrumentos utilizados são: imagens e relatos de práticas. Minha participação consistirá em contribuir com registros e anotações para elaboração dos relatos de prática. Compreendo que esse estudo possui finalidade de pesquisa, e que os dados obtidos serão divulgados seguindo as diretrizes éticas da pesquisa, assegurando, assim, minha privacidade. Sei que posso retirar meu consentimento quando eu quiser, e que não receberei nenhum pagamento por essa participação.

Nome: Sabrina Mantovani Passos
Assinatura: Saluina mantowni farnos

São Paulo $29 / 07 / 2019$. 


\section{Termo de Consentimento Livre e Esclarecido}

Concordo em participar, como voluntário/a, da pesquisa intitulada As especificidades da educadora de 0 a 3 anos - a construção de um novo papel desenvolvida junto à Faculdade de Educação da Universidade de São Paulo pelo/a pesquisador/a Ana Paula Yazbek, orientado/a por Rosa Iavelberg os/as quais podem ser contatados/as pelo e-mail anayazbek@usp.br ou rosaiave@usp.br ou telefone 11 99666-5612

O presente trabalho tem por objetivos: analisar o papel das educadoras dos bebês e das crianças pequenas e os instrumentos utilizados são: imagens e relatos de práticas. Minha participação consistirá em contribuir com registros e anotações para elaboração dos relatos de prática. Compreendo que esse estudo possui finalidade de pesquisa, e que os dados obtidos serão divulgados seguindo as diretrizes éticas da pesquisa, assegurando, assim, minha privacidade. Sei que posso retirar meu consentimento quando eu quiser, e que não receberei nenhum pagamento por essa participação.

Nome: Samantha Nascimento Santos

Assinatura:

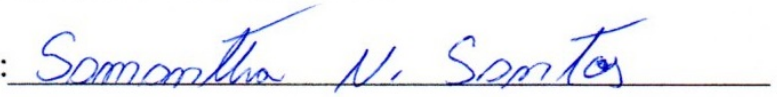

São Paulo $29 / 07 / 2019$.

\section{Termo de Consentimento Livre e Esclarecido}

Concordo em participar, como voluntário/a, da pesquisa intitulada As especificidades da educadora de 0 a 3 anos - a construção de um novo papel desenvolvida junto à Faculdade de Educação da Universidade de São Paulo pelo/a pesquisador/a Ana Paula Yazbek, orientado/a por Rosa Iavelberg os/as quais podem ser contatados/as pelo e-mail anayazbek@usp.br ou rosaiave@usp.br ou telefone 11 99666-5612

$\mathrm{O}$ presente trabalho tem por objetivos: analisar o papel das educadoras dos bebês e das crianças pequenas e os instrumentos utilizados são: imagens e relatos de práticas. Minha participação consistirá em contribuir com registros e anotações para elaboração dos relatos de prática. Compreendo que esse estudo possui finalidade de pesquisa, e que os dados obtidos serão divulgados seguindo as diretrizes éticas da pesquisa, assegurando, assim, minha privacidade. Sei que posso retirar meu consentimento quando eu quiser, e que não receberei nenhum pagamento por essa participação.

Nome: Vanessa Almeida da Silva

Assinatura: Vanesso A de Siba

São Paulo $29 / 07 / 2019$. 
